\title{
TREE WATER USE STRATEGIES IN A NEOTROPICAL DRY FOREST
}

Dissertation

zur Erlangung des akademischen Grades Doctor of Philosophy (PhD)

der Fakultät für Forstwissenschaften und Waldökologie

der Georg-August-Universität Göttingen.

vorgelegt von

Philipp Butz

geboren in Duisburg, Deutschland.

Göttingen, 25.06.2019 
1. Gutachter: Prof. Dr. Dirk Hölscher

2. Gutachter: Prof. Dr. Bernhard Schuldt

3. Gutachter: Prof. Dr. Holger Kreft

Tag der mündlichen Prüfung: 04.09.2019 



\section{ABSTRACT}

Trees in tropical dry forests (TDFs) developed different drought coping strategies including e.g. succulence of different plant organs, wood anatomical traits and leaf phenology. Apart from the fact that water availability limits plant physiological activity our understanding of the eco-physiological mechanisms underlying species' responses to water stress remains still limited. Varying temporal and spatial precipitation patterns which are assumed to influence tree phenology, growth and water turnover make it a complex task to predict global and local change scenarios. The objective of this study was to 1) assess patterns in leaf phenology, radial stem circumference changes, sap flux responses and evaluate their potential suitability as climate change indicators, 2) to delineate the influence of phenology, fluctuating moisture regimes and site conditions on species specific water use responses, 3) and to analyze stem water residence time in the different functional species. The study was implemented along an elevational and moisture gradient in a sub montane dry forest of southern Ecuador. Methods include sap flux measurement techniques (thermal dissipation probes and heat field deformation), phenological observations and stable isotope tracing (Deuterium Oxide). Tree species of four different phenological types (after Borchert, 1996) were assessed at $670 \mathrm{~m}, 860 \mathrm{~m}$, and $1100 \mathrm{~m}$ asl.

In search of a potential climate change indicator, three leaf deciduous tree species were studied: Ceiba trichistandra (leaf deciduous, stem succulent), Eriotheca ruizii (deciduous) and Erythrina velutina (brevi-deciduous). At three altitudes 36 trees were equipped with digital band dendrometers and thermal dissipation probes (Granier, 1987). Phenology was observed during the whole study period. Basically all species reacted to the environmental drivers (vapor pressure deficit, VPD and soil water content, SWC) with shrinking and swelling of the stem circumference and particular sap flux patterns during the whole study period at all elevations. Stem succulent Ceiba responded most sensitive to drivers; even after shedding leaves it was the first species able to re-flush some canopy, triggered by an intermittent rain event. Stem water in Ceiba presumably serves to flush leaves one month before onset of the first rains in the wet season, marked in the dendrometer readings by a strong decrease of circumference. This extraordinary sensitivity toward changing moisture regimes makes Ceiba a useful indicator species for assessing climatic variations. Furthermore, the study setup revealed differences among species, tree water use patterns, radial growth and topographic position; therefore raising the question of species' specific drought coping mechanism. We subsequently focused on the influence of variation in SWC (supposed to control water use), VPD, species (representing phenology), elevation, and tree diameter on water use to derive species' specific responses. The evergreen (broad-leaved) Capparis scabrida was added to the study setup to cover all functional phenological types (Borchert, 1996). At high SWC levels a typical scaling relationship for tree water use and diameter for all species was found. However, declining SWC levels affected sap flux patterns of species differently: The evergreen Capparis increased sap flux whereas the stem succulent, leaf deciduous Ceiba and other deciduous tree species reduced sap flux sensitively. Diurnal hysteresis 
loops of sap flux vs. VPD under dry SWC conditions indicated that Ceiba and the deciduous tree species decreased transpiration, whereas Capparis increased transpiration compared to wet conditions. Potential access to deeper soil water resources might explain the fact that Capparis tolerated top soil drought whereas the deciduous species followed a drought avoidance strategy by being leafless in the dry season. The role of the stem succulence for drought coping seems to relate to phenological uses. The study indicates a strong influence of species' drought coping strategy on water use patterns in this TDF.

To further verify the actual role of stem water in tree water use of the co-existing coping strategies we used stable isotope tracing to assess stem water residence time. Five species were studied, tracing results yielded species-specific mean residence times between 11 and 22 days. Ceiba and two other leaf deciduous tree species had residence times about twice as high as those of two evergreen tree species. Generally, residence times increase with tree diameter and decrease with wood density as suggested by our findings and literature data, soil moisture did not significantly affect water residence times. Accordingly, Ceiba's big stem and low wood density explain the extended residence time. The succulent stem may however play a special role for leaf flushing at the end of the dry season.

The pronounced differences in water use and drought coping strategies among species and phenological types might play a key role in predicting impacts of varying precipitation patterns and amounts for TDFs. Deciduous species, in contrast to evergreens, seem to be better adapted to predicted climate change scenarios, due to their ability to avoid drought and respond fast to short rain events. In times of cheap, high resolution satellite imagery, deciduousness has the potential to become a powerful drought indicator. This hypothesis is based on the assumption that precipitation is the factor restricting plant physiological activity and is responsible for breaking bud dormancy in TDFs. If increasing time spans between precipitation events lower groundwater tables, groundwater-tapping evergreen species may encounter very harsh conditions. In case rain becomes more abundant, deciduous species seem to be able to stay fully leaved all year around, making them strong competitors for evergreen species. Specialized forms of deciduousness, like stem succulence might lead to further advantages on top of being solely leaf deciduous. 


\section{ZUSAMMENFASSUNG}

Bäume in tropischen Trockenwäldern entwickelten verschiedene Trockenbewältigungsstrategien, darunter z.B. Sukkulenz verschiedener Pflanzenorgane, holzanatomische Merkmale und Blattphänologie. Abgesehen davon, dass die Wasserverfügbarkeit die pflanzenphysiologische Aktivität begrenzt, ist unser Verständnis der ökophysiologischen Mechanismen, die den Reaktionen der Arten auf Wasserstress zugrunde liegen, noch immer begrenzt. Unterschiedliche zeitliche und räumliche Niederschlagsmuster, von denen angenommen wird, dass sie die Baumphänologie, das Wachstum und den Wasserumsatz beeinflussen, machen es zu einer komplexen Aufgabe, globale und lokale Veränderungsszenarien vorherzusagen. Das Ziel dieser Studie war es, 1) Muster in der Blattphänologie, radiale Stammumfangsänderungen, Saftflussreaktionen und ihre potenzielle Eignung als Klimaindikatoren zu bewerten, 2) den Einfluss der Phänologie, schwankende Feuchtigkeitsregime und Standortbedingungen auf artspezifische Wassernutzungsreaktionen abzugrenzen, 3) und die Verweildauer des Stammwassers in den verschiedenen funktionellen Arten zu analysieren. Die Studie wurde entlang eines Höhen- und Niederschlagsgradienten (Feuchtigkeit nimmt mit der Höhe zu) in einem submontanen Trockenwald im Süden Ecuadors durchgeführt. $\mathrm{Zu}$ den Methoden gehören Saftflussmesstechniken (Wärmeableitungssonden und Wärmefelddeformationen), phänologische Beobachtungen und stabile Isotopenverfolgung (Deuterium Oxid). Baumarten von vier verschiedenen phänologischen Typen (nach Borchert, 1996) wurden auf 670 m, 860 m und 1100 m über NN bewertet.

Auf der Suche nach einem potenziellen Indikator für den Klimawandel wurden drei funktionell verschiedene Arten der Laubbaumgruppe untersucht: Ceiba trichistandra (laubabwerfend, stammsukkulent), Eriotheca ruizii (laubabwerfend) und Erythrina velutina (kurz-laubabwerfend). In drei Höhenlagen wurden 36 Bäume mit digitalen Banddendrometern und Saftflusssonden (Granier, 1987) ausgestattet. Die Phänologien wurden während des gesamten Untersuchungszeitraums beobachtet. Grundsätzlich reagierten alle Arten auf die Umweltfaktoren Wasserdampfdruckdefizit, ("Vapor Pressure Deficit", VPD) und Bodenwassergehalt ("Soil Water Content", SWC) mit Schwinden und Schwellen des Stammumfangs und speziellen Saftflussmustern während des gesamten Untersuchungszeitraums in allen Höhenlagen. Die stammsukkulente Ceiba reagierte am empfindlichsten auf die Einflüsse; nach dem Abwerfen der Blätter am Ende der Regenzeit war sie die erste Art, die in der Lage war, wieder auszutreiben, ausgelöst durch ein intermittierendes Regenereignis innerhalb der Trockenzeit. Das Stammwasser in Ceiba dient vermutlich dazu, Blätter einen Monat vor Beginn der ersten Regenfälle in der Regenzeit auszutreiben, was in den Dendrometer Daten durch eine starke Abnahme des Umfangs gekennzeichnet ist. Diese außergewöhnliche Empfindlichkeit gegenüber sich ändernden Feuchtigkeitsregimen macht Ceiba zu einer nützlichen Indikatorart für die Beurteilung von Klimaschwankungen. Darüber hinaus deutete die Studie Unterschiede zwischen den Arten, der Wasserverwendungsmuster, dem radialen Wachstum sowie der topografische Lage an und wirft die Frage nach artspezifischen Trockenheitsbewältigungsmechanismen auf. 
Wir konzentrierten uns anschließend auf den Einfluss von Variationen in SWC (die maßgeblich den Wasserverbrauch bestimmen sollen), VPD, Arten (repräsentativ für Phänologie), Höhe und Baumdurchmesser auf den Wasserverbrauch, um die spezifischen Reaktionen der Arten abzuleiten. Die immergrüne (breitblättrige) Capparis scabrida wurde dem Studienaufbau hinzugefügt, um alle funktionellen phänologischen Typen abzudecken (Borchert, 1996). Bei hoher Bodenwasserverfügbarkeit wurde eine typische Skalierungsbeziehung für die Nutzung des Baumwassers und den Baumdurchmesser für alle Arten gefunden. Allerdings wirkte sich sinkende Bodenwasserverfügbarkeit auf die Saftflussmuster der Arten unterschiedlich aus: Die immergrüne Capparis erhöhten den Saftfluss, während die stammsukkulente, laubabwerfende Ceiba und andere Laubbaumarten den Saftfluss empfindlich reduzierten. Tägliche Hystereseschleifen des Saftflusses vs. VPD unter trockenen SWC- Bedingungen zeigten, dass Ceiba und die Laubbaumarten die Transpiration verringerten, während Capparis die Transpiration im Vergleich zu feuchten Bedingungen erhöhte. Ein möglicher Zugang zu tieferen Bodenwasserressourcen könnte die Tatsache erklären, dass Capparis die Dürre im Oberboden tolerierte, während die Laubbäume einer Strategie zur Vermeidung von Dürren folgten (Blattabwurf in der Trockenzeit). Die Rolle der Stamm-Sukkulenz bei der Dürrebewältigung scheint sich auf phänologische Zwecke zu reduzieren. Die Studie zeigt einen starken Einfluss der arteigenen Strategie zur Bewältigung der Dürre auf die Wassernutzungsmuster in diesem Trockenwald.

Um die tatsächliche Rolle des Stammwassers bei der Nutzung der bestehenden Bewältigungsstrategien weiter zu überprüfen, haben wir eine stabile Isotopenverfolgung verwendet, um die Verweildauer des Stammwassers zu beurteilen. Fünf Arten wurden untersucht, die Ergebnisse lieferten artspezifische mittlere Verweilzeiten zwischen 11 und 22 Tagen. Ceiba und zwei weitere Laubbaumarten hatten eine etwa doppelt so hohe Verweildauer als zwei immergrüne Baumarten. Im Allgemeinen steigen die Verweilzeiten mit dem Baumdurchmesser und sinken mit der Holzdichte, wie unsere Ergebnisse und Literaturdaten vermuten lassen. Die Bodenfeuchte hatte keinen signifikanten Einfluss auf die Verweilzeiten des Wassers. Dementsprechend erklären der große Stamm von Ceiba und die geringe Holzdichte die verlängerte Verweilzeit. Das Wasserreservoir des sukkulenten Stamms scheint jedoch eine besondere Rolle beim Laubaustrieb zu spielen.

Die ausgeprägten Unterschiede in der Wassernutzung und den Trockenheitsbewältigungsmechanismen zwischen den Arten und phänologischen Typen könnten eine Schlüsselrolle bei der Vorhersage der Auswirkungen unterschiedlicher Niederschlagsmuster und -mengen für TDFs spielen. Laubabwerfende Bäume scheinen im Gegensatz zu Immergrünen besser an vorhergesagte Szenarien des Klimawandels angepasst zu sein, da sie in der Lage sind, Dürren zu vermeiden und schnell auf kurze Regenfälle zu reagieren. In Zeiten kostengünstiger, hochauflösender Satellitenbilder haben Laubabwerfende Bäume das Potenzial, ein starker Dürreindikator zu werden. Diese Hypothese basiert auf der Annahme, dass Niederschlag der Faktor ist, der die pflanzenphysiologische Aktivität einschränkt und für die Beendigung der Keimruhe in TDFs verantwortlich ist. Wenn die Zeitspanne zwischen den 
Niederschlagsereignissen immer länger wird und der Grundwasserspiegel sinkt, können immergrüne Arten auf sehr harte Bedingungen stoßen. Falls der Regen häufiger wird, scheinen Laubabwerfende Bäume das ganze Jahr über voll belaubt zu bleiben, was sie zu starken Konkurrenten für immergrüne Arten macht. Spezielle Formen des Laubabwurfs, wie z.B. die Stammsukkulenz, können weitere Vorteile mit sich bringen. 


\section{Table of Contents}

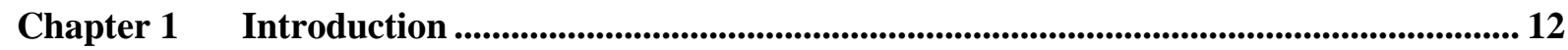

1.1 Tropical dry forests: Extension, climatic characteristics and threats .............................. 12

1.2 Trees in Neotropical dry forests: Structure, phenology and ecophysiology ..................... 14

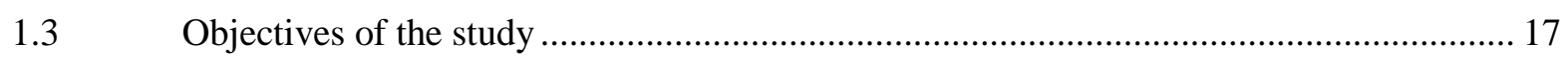

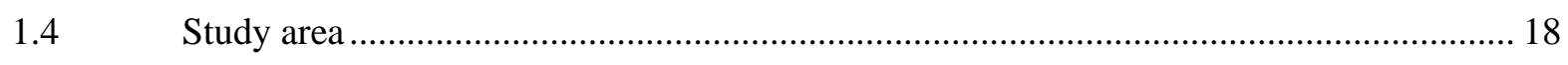

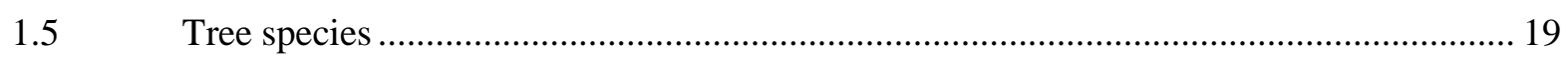

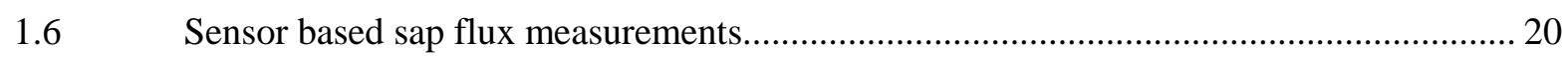

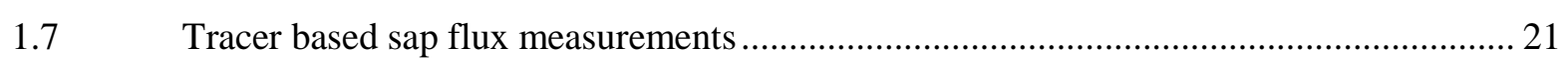

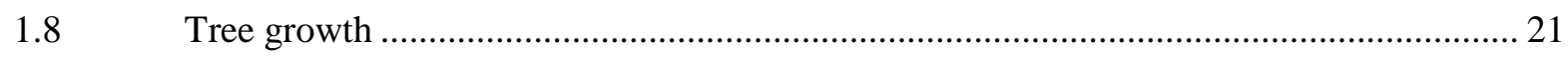

$1.9 \quad$ Meteorological and environmental measurements ...................................................... 21

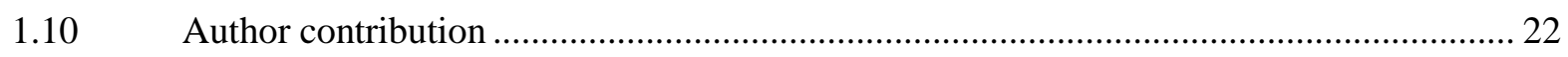

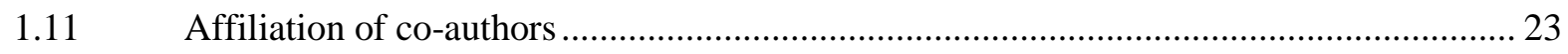

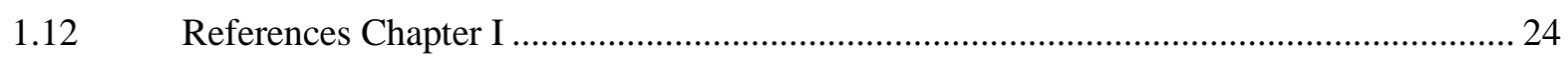

Chapter 2 Tree responses to moisture fluctuations in a neotropical dry forest as potential

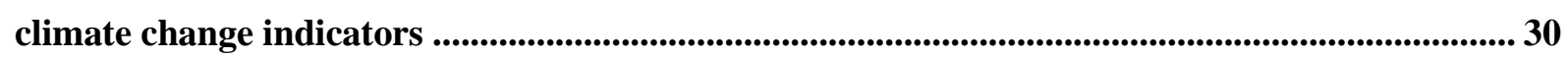

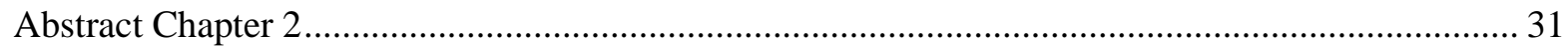

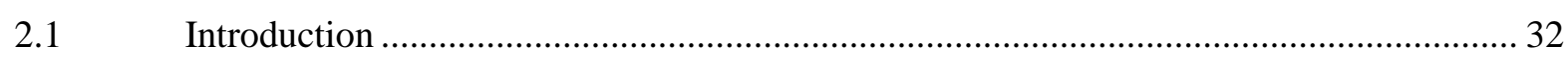

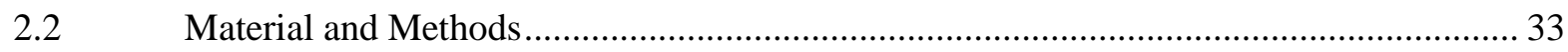

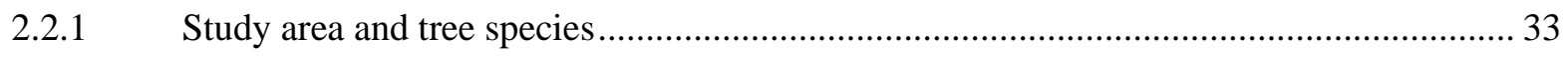

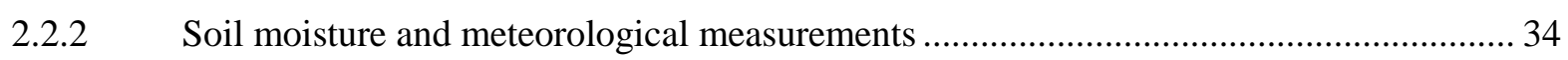

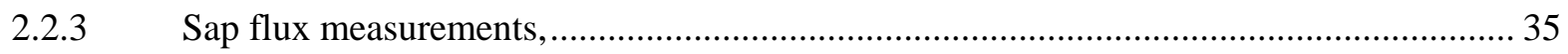

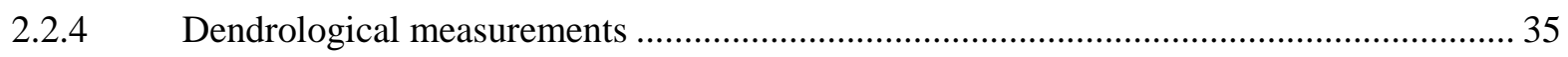

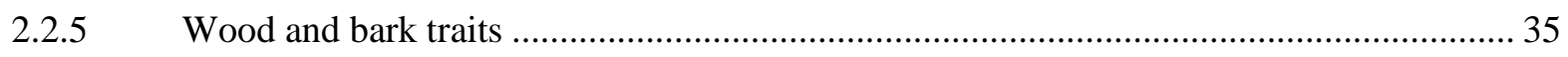

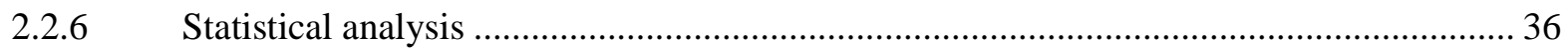

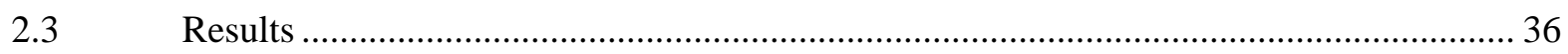

2.3.1 Seasonality of leaf phenology and changes in stem circumference ................................ 36

2.3.2 Influence of different climatic periods on tree behavior along the elevational gradient ... 40

2.3.3 Tree response to intermittent rain fall events in the dry season ...................................... 47 


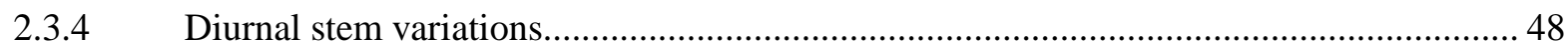

2.3.5 Main drivers of stem variations, sap flux density and leaf phenology .............................. 49

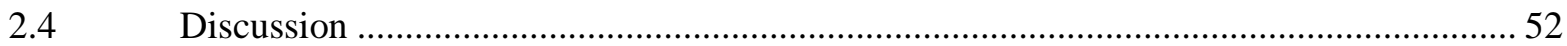

2.4.1 Response of diurnal stem diameter variations to fluctuating moisture regimes and climate.

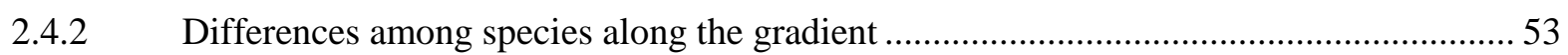

2.4.3 Tree indicators of climate change in a dry forest .......................................................... 54

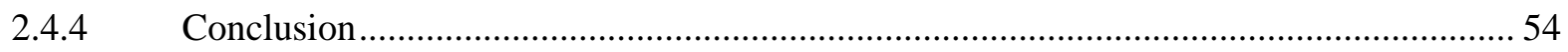

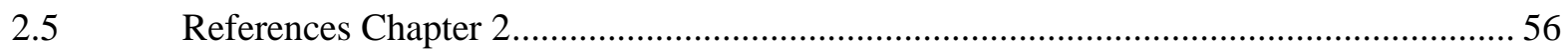

Chapter 3 Tree Water Use Patterns as Influenced by Phenology in a Dry Forest of Southern

Ecuador

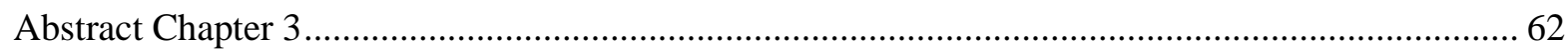

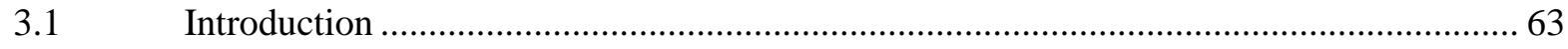

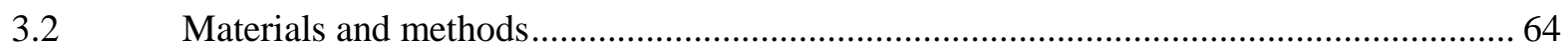

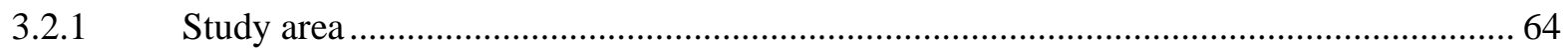

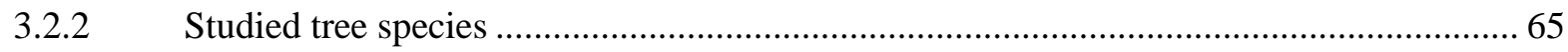

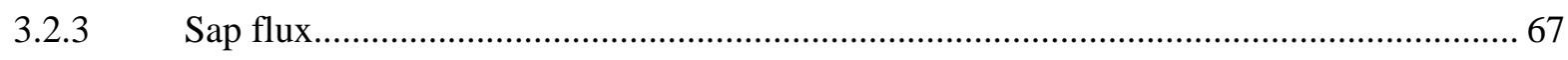

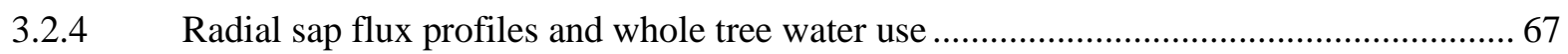

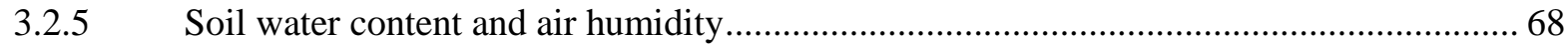

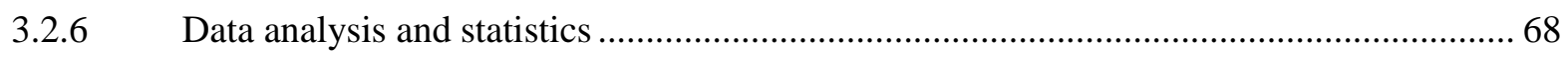

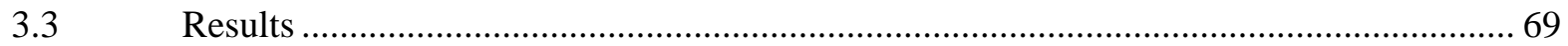

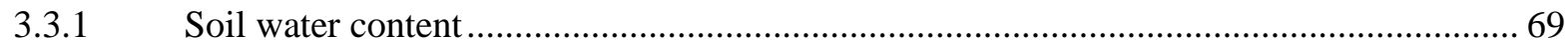

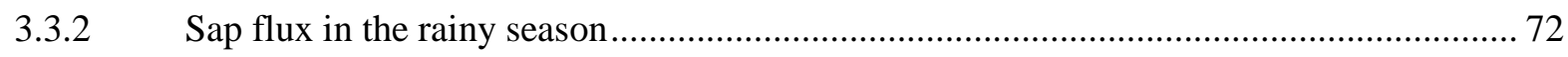

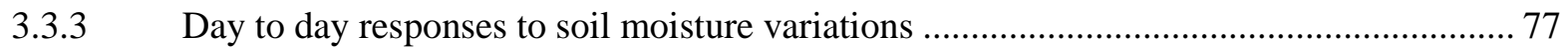

3.3.4 Diurnal hysteresis at dry and moist soil....................................................................... 79

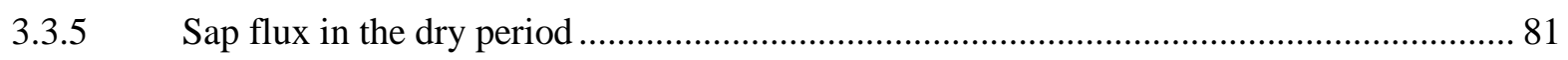

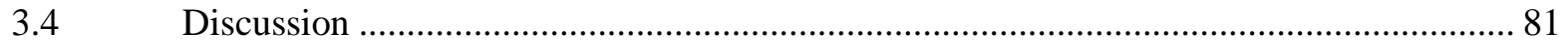

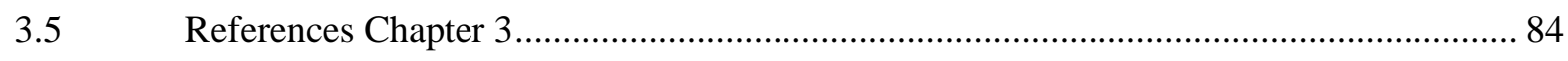

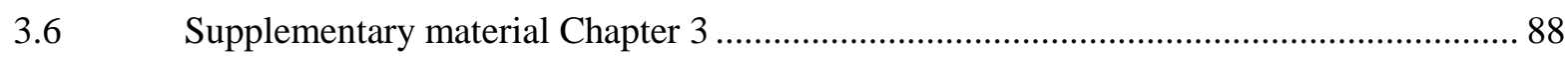

Chapter 4 Water residence times in trees of a neotropical dry forest .........................................95 


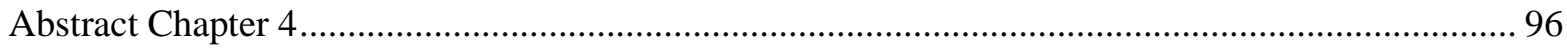

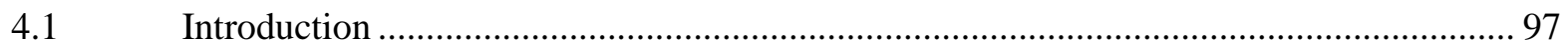

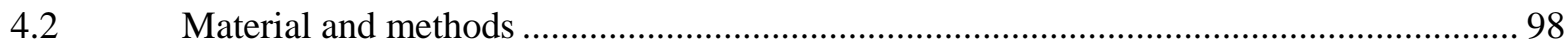

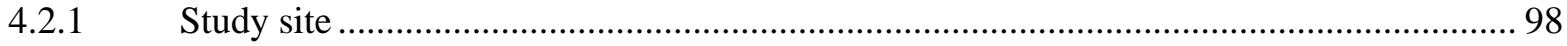

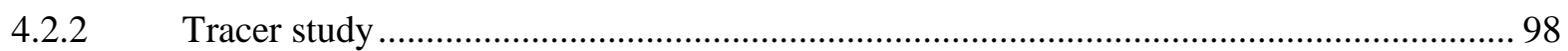

4.2.3 Soil moisture, micrometeorological and tree structural measurement ........................... 100

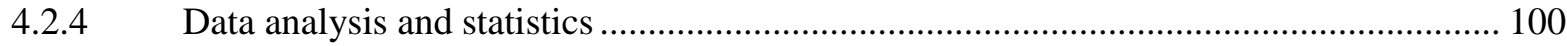

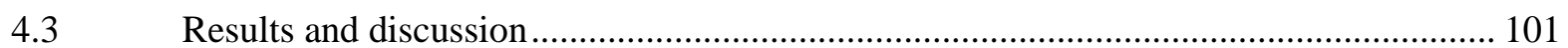

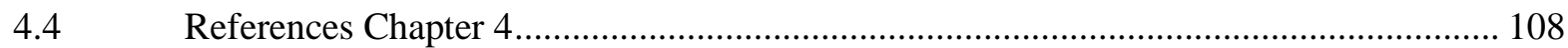

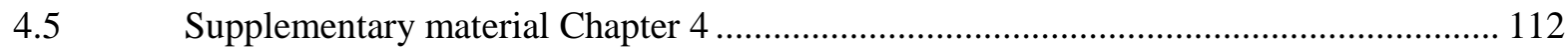

Chapter 5 Synthesizing drought coping strategies of Neotropical dry forest species............. 117

5.1 Consequences of moisture variations on phenology, stem water status and sap flux ..... 117

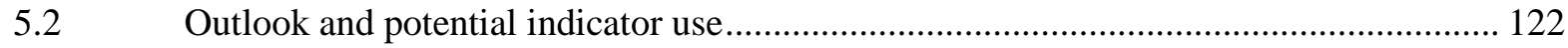

$5.3 \quad$ References Chapter 5

Index of figures ...................................................................................................................................................... 129

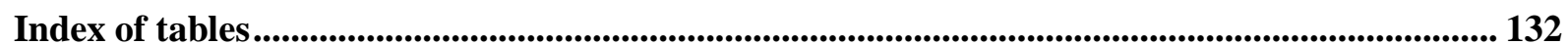

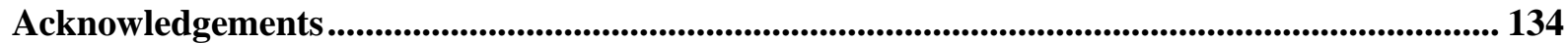

Declaration of honor ........................................................................................................................................... 136

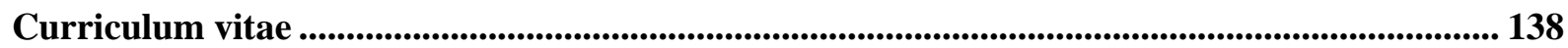




\section{Chapter 1 Introduction}

\subsection{Tropical dry forests: Extension, climatic characteristics and threats}

Approximately $17 \%\left(6.78\right.$ million $\left.\mathrm{km}^{2}\right)$ of the global forest cover $\left(38.81 \pm 1.34\right.$ million $\left.\mathrm{km}^{2}\right)$ were considered tropical and subtropical dry broadleaved forests in 2005 (Feng et al., 2016). In general estimates of the global extent of tropical dry forests (hereafter named TDF) vary between 1 and 7 million $\mathrm{km}^{2}$ depending on methods of assessment and the underlying definition of TDF (Mayaux et al., 2005; Miles et al., 2006; Hansen et al., 2013, Feng et al., 2016). Recently the percentage of forest area in dryland biomes has been found to be $40-47 \%$ higher than previously estimated, leading to an increase in global forest cover by at least 9\% (Bastin et al., 2017). These results face critical voices regarding e.g. methods (Cruz et al., 2017) and definitions (Griffith et al., 2017).

Spatial assessments of TDF depend critically on how this vegetation type is defined. This turned out to be a rather complex issue, as dry forests merge into other vegetation types such as wet forests, savannas and woodlands all over the tropical latitudes (Furley et al., 1992, Miles et al., 2006). The attempt of Mooney et al. (1995) to overcome these problems by defining TDFs as forests that develop under similar climatic conditions (e.g. pronounced seasonality in rainfall distribution), analogous structures and physiognomies, lack precise characterization of shared traits as they themselves point out (Mooney et al., 1995). Furthermore, the forest definition itself remains up for debate; definitions solely based on e.g. tree cover, like in Bastin et al. (2017), are supposed to ignore key functional differences between closedand open-canopy vegetation types (Griffith et al., 2017). Up to date, manifold forest and dry forest definitions exist, often adapted towards the particular research questions of the authors, but not yet unified.

According to Miles et al. (2006), who used a biogeographic classification based on Olson et al. (2001) in combination with a $40 \%$ forest cover, the two most extensive continuous areas of TDFs are located in South America, one in north-eastern Brazil, and the other one in south-eastern Bolivia, Paraguay and northern Argentina (Figure 1.1). Accordingly, the Neotropics hold more than half $(54.2 \%)$ of the remaining area of this vegetation type (Miles et al., 2006). Other, smaller and more isolated regions of TDF expansion occur in the dry valleys of the Andes in Ecuador, Peru and Bolivia, Coastal Ecuador and northern Peru, in Central Brazil and scattered throughout the Brazilian Cerrado biome (Pennington et al., 2000). Of the entire protected TDF area, approximately $70 \%$ is found in the Neotropics (Miles et al., 2006). 


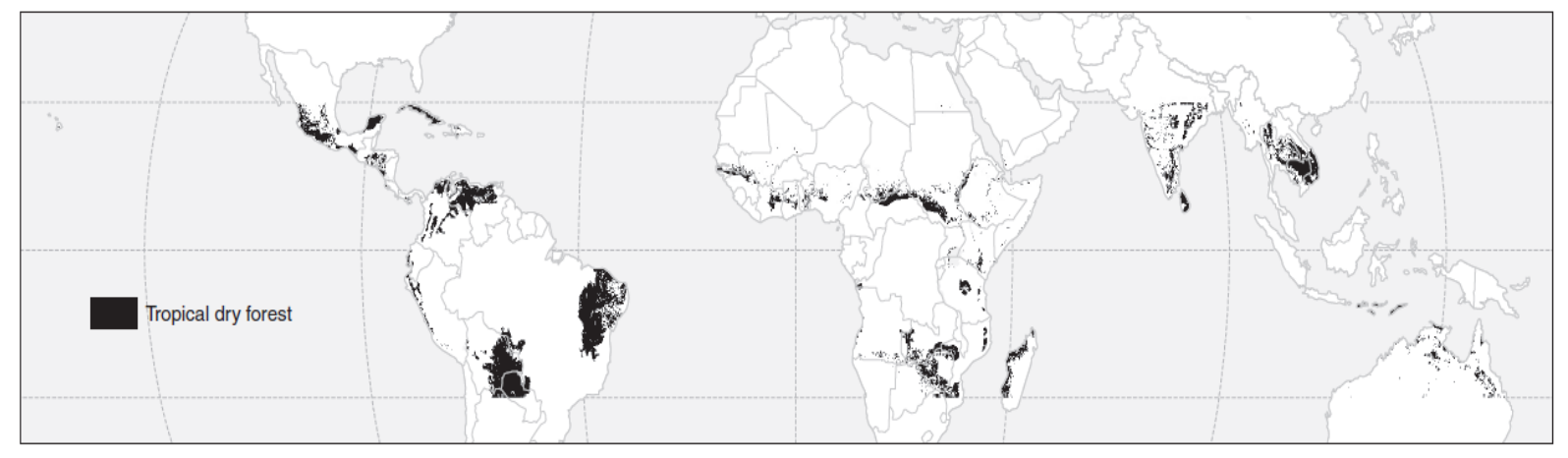

Figure 1.1 Global distribution of tropical dry forest in the year 2000, displayed as 10-km cells containing this forest type (including plantations in tropical dry forest areas) (Miles et al. 2006).

Other continuous areas of TDFs are located within the Yucatan peninsula of Mexico, northern Venezuela and Colombia, and in Central Indochina (Thailand, Vietnam, Laos and Cambodia) (Miles et al., 2006). The majority of the remaining dry forest areas appear highly scattered or fragmented, stretched over extensive geographical ranges, like the Pacific coast of Mexico, eastern India and Sri Lanka, in the island chain east of Java, and in northern Australia (Miles et al., 2006, Bastin et al., 2017). Specifically on the African Continent, TDFs are characterized by an extensive spatial distribution, without larger continuous areas. Scattered dry forests can be found in western Madagascar, and in West Africa (principally Mali), whereas the most important and connected centers of distribution are located in western Ethiopia, southern Sudan and the Central African Republic, and in Zambia, Zimbabwe and Mozambique (Miles et al., 2006).

To unify definitions for drylands a global definition-initiative came up with an aridity index (AI) based on precipitation availability over atmospheric water demand. The AI accordingly is the ratio of mean annual precipitation and mean annual potential evapotranspiration (UNEP, 1997). According to this definition, drylands are characterized by an AI < 0.65 (< 0.03 "Hyper Arid", 0.03-0.2 "Arid", 0.2-0.5 "Semi-Arid", 0.5-0.65 "Dry sub-humid", > 0.65 "Humid") (UNEP, 1997). The definitions for TDFs have to be further specified, as despite their classification as "dry" forests, they can receive large amounts of annual precipitation relative to most temperate forests (Chave et al., 2006). They occur at latitudes $23.5^{\circ}$ North to $23.5^{\circ}$ South from the Equator in areas where rainfall ranges from 500 to 1800 mm year ${ }^{-1}$ with a marked dry season of at least 5-6 month (precipitation less than $100 \mathrm{~mm} \mathrm{month}^{-1}$ ) (Murphy and Lugo, 1986, Gentry, 1995).

The latitudinal position strongly influences timing and frequency of dry periods, with the shortest and least severe dry periodes found at or within several degrees north and south of the equator (Murphy and Lugo, 1986). The amount and seasonality of rainfall strongly influence eco-hydrological processes as well as tree phenology, physiology and structure; and different drought coping strategies usually coexist in these forests (Borchert, 1994a; Schwinning and Ehleringer, 2001; Borchert et al., 2004). This considerable diversity in water relations in different functional ecotypes possibly occurs as drought- 
induced water stress is a major cause of leaf-fall (Holbrook et al., 1995) and stem rehydration is a precondition for bud break of vegetative bud (Reich et al., 2002). Changes of temperature and precipitation regimes for tropical and subtropical forest regions of the world are common, consequently these ecosystems are likely to face severe changes, which should be monitored closely (Gitay et al., 2002; Hansen et al., 2013; Seddon et al., 2016).

Generally, a key feature of the diversity in these dryland ecosystems is the high inter-annual variability in their precipitation regime (Le Houérou, 2001). While earlier climate change research mostly analyzed the impacts of changes in the major climate variables, the importance of precipitation as a key driver of ecosystem dynamics in drylands is by now largely acknowledged (D’Odorico et al., 2005, Borgogno et al., 2007). Predicted changes in climate change related plant productivity in these ecosystems (Easterling et al., 2000, NAST, 2001, Bates et al., 2008) requires understanding of physiological responses of arid and semi-arid vegetation to soil and atmospheric drought. Equally, underlying mechanisms for accurate prediction of long-term carbon, water and energy fluxes to provide a more mechanistic model of plantdrought relation need to be assessed (Naithani et al., 2012). Among the manifold drought predictions, five possible scenarios describe how future drought might influence seasonal rainfall in TDFs: 1) reduced rainfall during a given year, 2) altered dry season length, 3) altered timing of rainfall, 4) reduced rainfall coupled with altered dry season length, or 5) multi-year drought of sequential low rainfall years (Allen et al., 2017). Accordingly, the varying precipitation regimes and resulting effects remain largely unexplored and provide a vast number of scenarios to study evolution and species adaptation to extreme conditions (Maestre et al., 2012).

Global forest cover loss between 2000 and 2005, was higher in the dry tropics (2.9\%) than in the humid tropics (2.4\%) (Hansen et al., 2010). Of the remaining area of TDFs, 97\% are at risk, whereas threats differ between regions: In Eurasia influencing factors are agricultural conversions and human population density, whereas in Africa habitat fragmentation and fire were identified as key threats (Miles et al., 2006). In contrast, in the Americas climate change was determined as greatest risk (Miles et al., 2006).

South American dry forests reacted highly sensitive to precipitation variability over the past 14 years (Seddon et al., 2016). Given the ongoing global increase in the inter-annual variability of precipitation patterns and the predicted intensification of extreme events, basic research objectives should be strengthened to deepen knowledge of TDF ecosystem functioning and their possible coping strategies (Maestre et al., 2012, Greve et al., 2014, Chadwick et al., 2015).

\subsection{Trees in Neotropical dry forests: Structure, phenology and ecophysiology}

In terms of forest structure, TDFs are characterized by lower basal area as well as a lower canopy height than rain forests, and thorny and succulent species are prominent (Murphy and Lugo, 1986). In the Neotropics it includes formations as diverse as tall forest on the moister sites to cactus scrub on the most 
arid ones (Pennington et al., 2000). Leguminosae and Bignoniaceae dominate the woody floras of these forests throughout their range, but also Anacardiaceae, Capparidaceae, Euphorbiaceae, Flacourtiaceae, Myrtaceae, Rubiaceae, and Sapindaceae occur commonly (Gentry, 1995). Cactaceae are prominent in the understory and are important in the diversity of these forests (Gentry, 1995). TDFs are tree dominated with a continuous canopy, which becomes increasingly broken with an annual rainfall of 500 $\mathrm{mm}$ or less (Pennington et al., 2009). Seasonality determines ecological processes and net primary production is lower than in rain forests as growth mainly occurs during the wet season (Pennington et al., 2000).

Phenology is highly dependent on seasonal rainfall and vegetation occurs to be mostly deciduous during the dry season (Borchert, 1994b). Therefore, seasonal water deficit should modulate leaf development and senescence in TDF tree species (Mendivelso et al., 2016), accordingly the degree of deciduousness increases with declining rainfall, although the most arid forests have a marked increase in evergreen and succulent species (Mooney et al., 1995). Trees thriving in these ecosystems therefore have developed manifold drought coping strategies with respect to physiology, phenology and structure. Among the ecological adaptations of a species to a certain climate, phenology and different types of succulence (e.g. stem succulence) are the most obvious. Accordingly, Borchert (1996) classified trees growing in TDFs into four functional ecotypes which represent the species assessed in this study:

(1) Deciduous species, species that are found in the dry tropics with a distinct seasonality. They shed their leaves early in the dry season, followed by desiccation of the trunk. New foliage is flushed at the beginning of the next rainy season after first rains lead to a prior rehydration of their stems.

(2) Evergreen species are species mostly occurring in the humid tropics. They bear their foliage with a complete leaf exchange in the middle of the dry season. The new leaves flush first and then the old leaves are shed subsequently. They appear constantly foliated.

(3) Brevi-deciduous species, species that have a short leafless period persisting for some weeks during the dry season when they are flowering, afterwards they flush their new foliage.

(4) Stem-succulent species, species that appear mainly deciduous, but compared with deciduous species they shed their leaves earlier, at the end of the rainy season. The species remain leaf-less during the entire dry season, do not react to rainfall or irrigation and flush the new foliage early at the beginning of the new rainy season.

As for functional types there is a classification for drought coping strategies. Hereby deciduousness in its distinct forms serves as (1) drought avoidance whereas evergreen species aim at (2) drought tolerance, the two most commonly described drought coping strategies (Reich and Borchert, 1984; Borchert 1994a). Stem succulent species are part of the first group, avoiding drought at the cell level by using 
storage mechanisms to prevent the development of low water potentials in their photosynthetic tissue (Ogburn and Edwards, 2010).

Aside from plant available soil water, a variety of biotic factors such as structure and life span of leaves, wood density and capacity for stem water storage and rooting patterns determine the (stem) water status of a tree (Borchert, 1994a). Especially wood anatomical features regulate changes in stem water storage (Poorter et al., 2014; Rosell et al., 2014). As a result, particularly leaf phenology is tightly coupled to stem water content under changing water availability (Borchert, 1994a).

Seasonal water deficit is expected to influence leaf development and senescence in TDF tree species which translates into species specific radial-growth rates. Up to now, relatively few studies have dealt with the link between leaf phenology and radial growth at annual as well as intra-annual scales in TDF areas (e. g. Coster, 1927; Schöngart et al., 2002; Lisi et al., 2008; Worbes et al., 2013). A better knowledge of these relationships would enable us to understand long-term growth responses of TDFs to climate warming and drought (Worbes, 1995, 2002; Rozendaal and Zuidema, 2011) and could consistently be of use to develop drought related indicators.

Stem water storage has been described as another important factor to buffer the impact of seasonal drought as it enables flushing and flowering of trees in the dry season (Borchert, 1994a). It also contributes to the transpiration stream to support diurnal transpiration with sapwood-stored water (Tyree \& Yang, 1990; Goldstein et al., 1998). We learned from earlier studies, that tree trunk internal water storage contributes between 6 to $50 \%$ of the daily water budget of large trees depending on the species (Holbrook and Sinclair, 1992; Scholz et al., 2008; Carrasco et al., 2015). This led to the hypothesis that stem water storage might have evolved to enhance these capabilities and ensure water supply during short dry spells (Ogburn and Edwards, 2010). However, for stem succulent species Chapotin et al. (2006) observed that stored water in two baobab species (Adansonia spp.) was almost solely used to flush new leaves at the end of the dry season, just before the onset of the wet season. A similar phenomenon can be observed in the stem succulent Ceiba trichistandra of the present study, which flushes leaves at the end of the dry season normally one month before the onset of the wet season (Figure 1.2).

These interactions between tree transpiration, stem water storage and seasonally changing environmental factors result in species-specific patterns of phenology, growth and tree water use that have a high ecological significance in drought stressed environments (Singh and Kushwaha, 2016). 


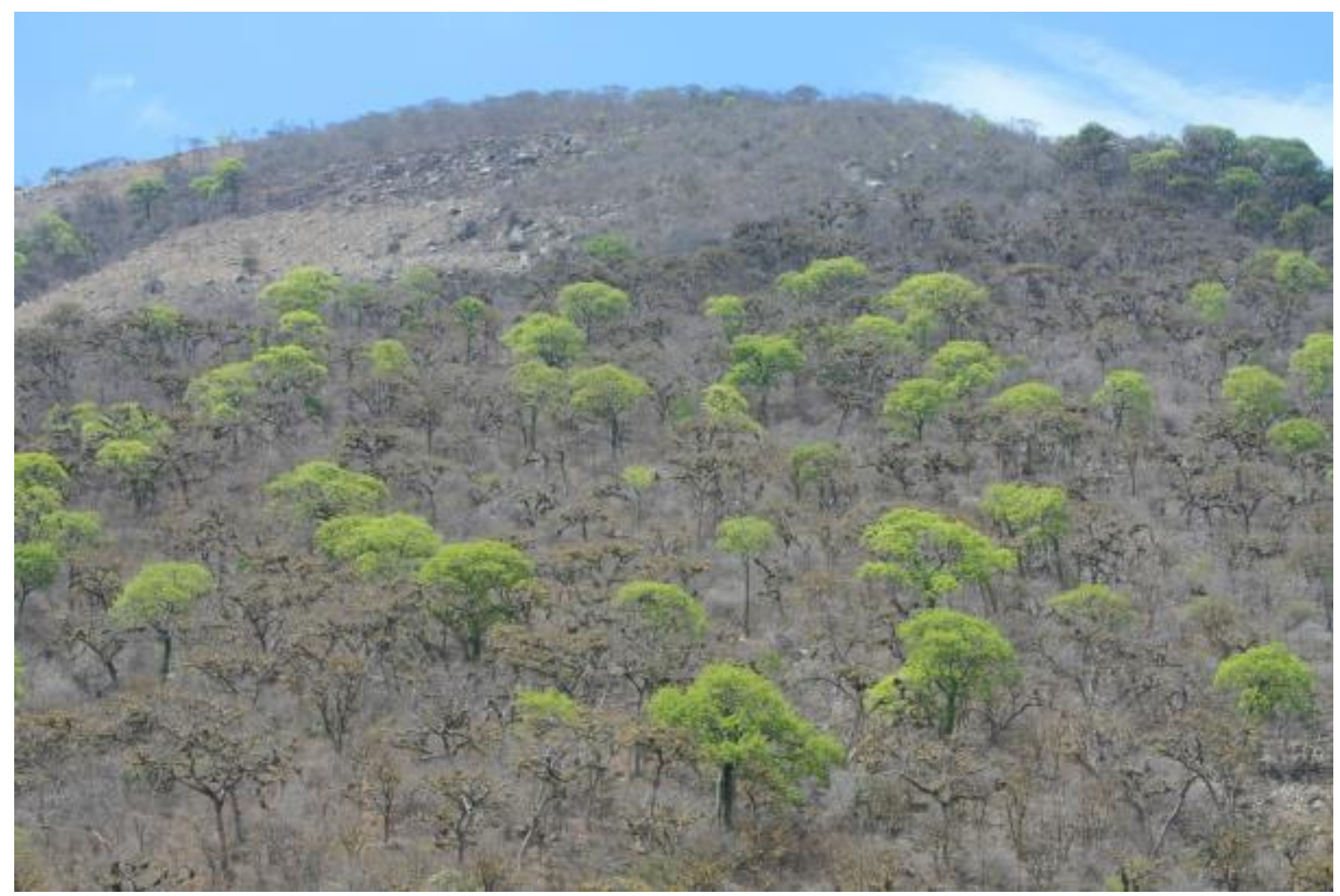

Figure 1.2 Ceiba trichistandra at the end of the dry season (December) is already flushing new foliage, while the other deciduous species remain leafless for another month.

\subsection{Objectives of the study}

This thesis is part of the DFG-funded collaborative project PAK823-825 "Platform for Biodiversity and Ecosystem Monitoring and Research in South Ecuador" (http://tropicalmountainforest.org/). The present work was implemented in the subproject C5 "Water consumption and carbon capture by trees of an evergreen and a dry forest in the Andes of South Ecuador as functional indicators of slow environmental changes".

The study aimed to assess tree water consumption, phenology, and tree diameter change by analyzing different drought coping strategies under the influence of changing moisture regimes along an elevational transect in a dry forest of Southern Ecuador. Data of the present study was combined with subproject A2 "Developing a tree-based indicator system for environmental change impacts on forest ecosystems in southern Ecuador". This allowed for additional analysis of growth patterns in combination with water use and phenology, enabling the development of tree based indicators.

The three main objectives were:

(1) To develop a functional tree based drought indicator for TDFs by combining sap flux, diameter change and phenological patterns (Chapter 2). 
(2) To analyze water use patterns of tree species in a TDF in southern Ecuador, as influenced by phenology and fluctuations in the environmental moisture regime (Chapter 3).

(3) To study tracer residence time in evergreen, deciduous non-stem succulent and deciduous stem succulent species as influenced by environmental conditions including soil moisture availability, assuming that water residence time in the deciduous stem succulent species will be larger than in the other species (Chapter 4).

The study aims to emphasize different eco-physiological drought responses among different TDF species, classified by phenology according to Borchert (1996). The results will contribute to better understanding different drought coping strategies of TDF species and might help evaluate their future growth under ongoing climate change scenarios.

This dissertation is composed of five chapters: Chapter $\mathbf{1}$ is a general introduction to the topic, including detailed information on the methodology used, Chapter 2-4 are three published manuscript and Chapter $\mathbf{5}$ is a synthesis of the former chapters.

\subsection{Study area}

The study was conducted in the Laipuna reserve, which is located in the Tumbesian dry forest ecoregion of southwestern Ecuador (Figure 1.3). In this region 272 tree species were recorded with, Leguminosae, Malvaceae, Cactaceae and Moraceae being the most species rich families (Linares-Palomino et al., 2009). The forest is mainly composed of deciduous species with co-occurring evergreens. Species richness peaked in the hills and decreased slightly towards the coastal lowlands and substantially towards higher altitudes (Homeier, pers. comm.). Generally, these forests occur on fertile soils with medium to high $\mathrm{pH}$ values, which make them suitable for agriculture especially at higher elevation due to higher moisture input (Velescu, 2016, pers. comm.). The altitude in the study area (hereafter referred to as "Laipuna Reserve") ranges from $600 \mathrm{~m}$ to $1400 \mathrm{~m}$ asl. and annual rainfall averages $540 \mathrm{~mm}$ but has a high inter annual variability (varying from 2007-2014 between 350-800 $\mathrm{mm} \mathrm{y}^{-1}$; 2007-2014, Spannl et al., 2016). Moisture availability increases with increasing elevation (Pucha-Cofrep et al., 2015; Spannl et al., 2016). The reserve has an average stem density of 410 stems ha $^{-1}$ and basal area of 28.5 $\mathrm{m}^{2} \mathrm{ha}^{-1} .39$ tree species were recorded in this forest, of which seven are evergreen and the remaining 32 deciduous (Homeier, unpublished). Soils were classified as Cambisols with a high skeleton fraction. The ecosystem is classified as premontane deciduous dry forest (Sierra, 1999; Aguirre et al., 2006). 


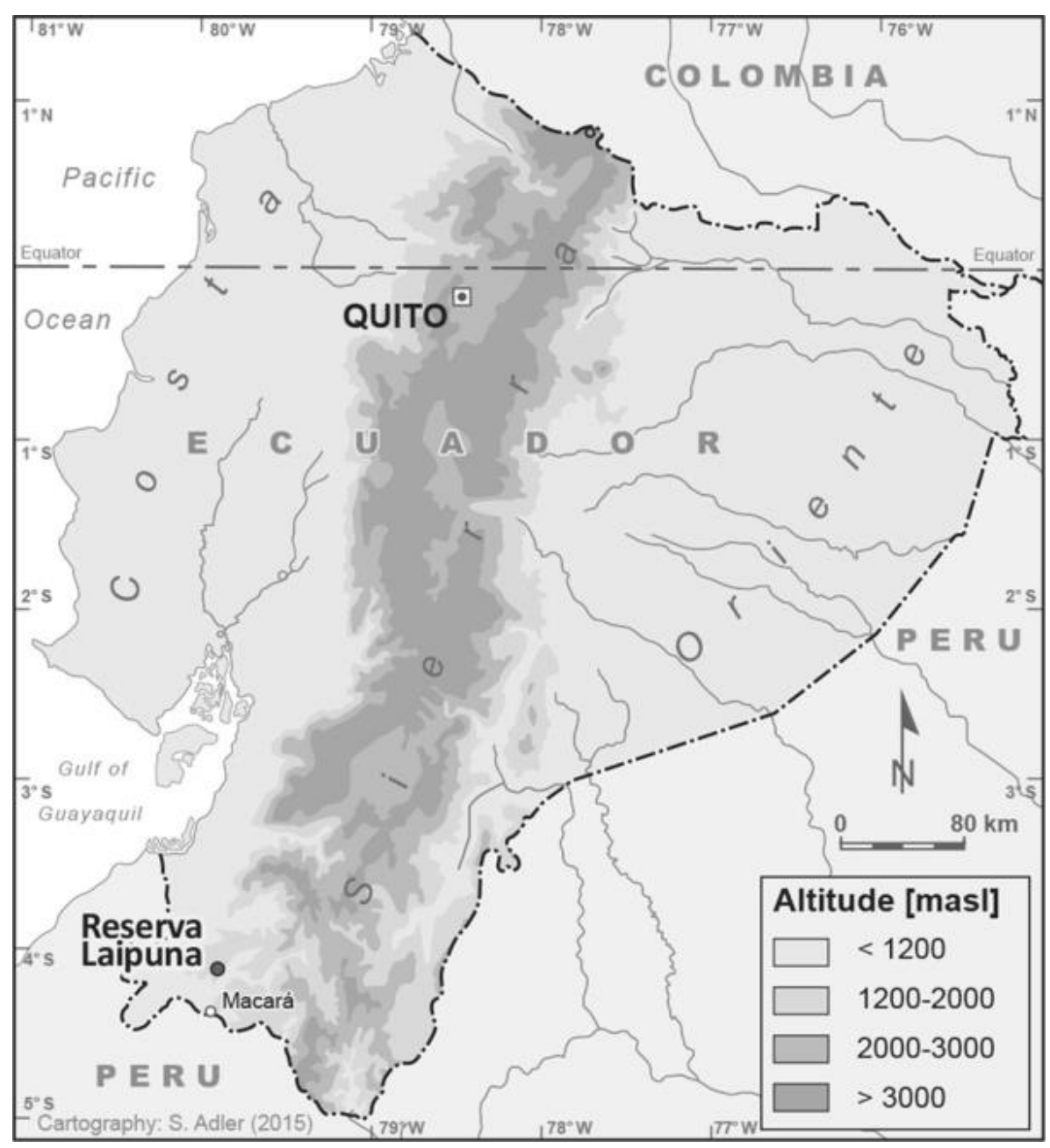

Figure 1.3 Map of Ecuador with study area shown in the south western tropical dry forest region. (adapted from Spannl et al., 2013)

\subsection{Tree species}

For this study four tree species were selected (Figure 1.4):

$>$ Eriotheca ruizii (K.Schum.) A. Robyns (Malvaceae),

$>$ Ceiba trichistandra (A. Gray) Bakh. (Malvaceae),

$>$ Erythrina velutina Willd. (Fabaceae),

Capparis scabrida Kunth (Capparaceae)

All four species are characteristic for the South Ecuadorian dry forest and have a high abundance in the study area. Importance Value Indices (IVI = relative abundance + relative dominance + relative frequency) according to Curtis and McIntosch (1951) were 37.4 for Ceiba, 48.3 for Eriotheca, 24.3 for Erythrina, and 7.86 for Capparis in this forest (Homeier, unpublished). Ceiba, Eriotheca and Erythrina are deciduous species whereas Capparis is an evergreen species. All deciduous species are canopy trees, which are abundant at all elevations, only the density of Ceiba decreases towards higher elevation. Capparis on the other hand remains a lower stature in the canopy and was not 
present at the highest altitude at $1100 \mathrm{~m}$ asl. Ceiba, Erythrina and Capparis are endemic to the region (Linares-Palomino et al., 2009), whereas Erythrina shows a wider distribution and is commonly used in reforestation projects, e.g. Brazil (Souza et al., 2016). All four species differ in their drought coping strategies, which make them interesting study objects as indicator species, i.e. Ceiba is leaf deciduous stem succulent, Eriotheca deciduous, and Capparis is evergreen. Erythrina has been found to be brevi-deciduous according to Cueva and Acarró (2011), but in our study region showed a similar leaf exchange behavior than the other deciduous species (despite its flowering during the dry season, which is a brevi-deciduous trait).

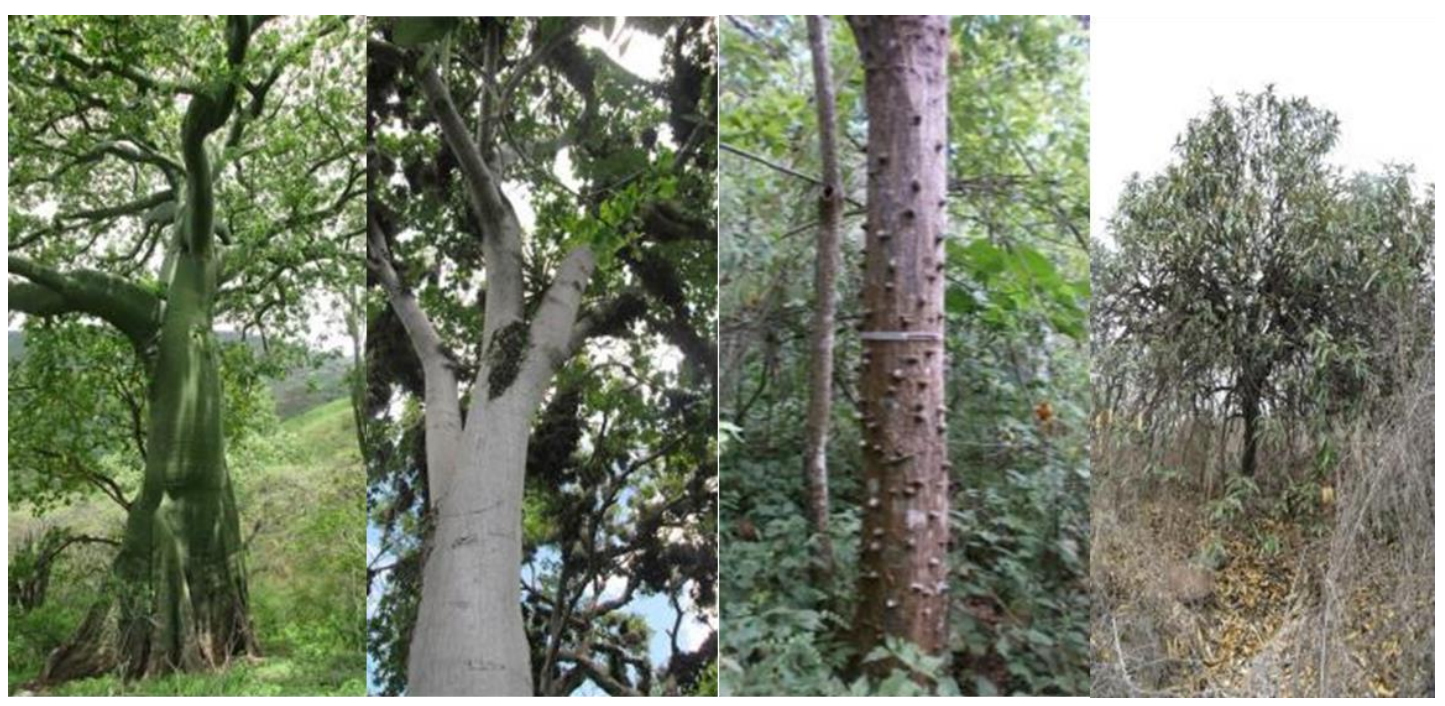

Figure 1.4 Studied tree species from left to right: Ceiba trichistandra (stem succulent deciduous), Eriotheca ruizii (deciduous), Erythrina velutina (brevi-deciduous) and Capparis scabrida (evergreen) fully leaved during the wet season.

\subsection{Sensor based sap flux measurements}

Sap flux techniques are a commonly applied tool to assess transpiration rates of trees, as they provide estimates of plant water use at high temporal resolution. Thermal dissipation probes (TDP after Granier 1985) are a frequently applied method at relatively low cost, which allow a high number of spatial replicates. The sensors consist of a pair of probes (one heated and one un-heated reference element, $250 \mathrm{~mW}, 12 \mathrm{~V}$ ), inserted with a distance of $10 \mathrm{~cm}$ between probes into pre-drilled holes in the stem (holes fitted with aluminum sleeves). Data was sampled every 30 seconds and averages stored every 30 minutes on a CR1000 data logger (Campbell Scientific Inc., Logan, UT, USA). Sensors were protected by aluminum foil covered Styrofoam boxes to minimize environmental influences. Calculation of the actual sap flux density is empirically derived following the original approach of Granier (1985). 


\subsection{Tracer based sap flux measurements}

The application of hydrogen isotope tracers (Deuterium Oxide, D2O, 99 atom\% D, Sigma-Aldrich, Germany) injected into the transpiration stream of the tree is another technique to measure plant water use (Calder, 1986). This technique has the advantage of being independent of power supply, allowing for sampling in remote areas. Additionally, the possibility to determine the tracers' residence time in the tree can reveal information on water storage patterns. Overall, tracer techniques are very useful in combination with other sap flux devices to gather additional data on tree sap flux and storage to derive a complex picture of tree water use characteristics.

\section{$1.8 \quad$ Tree growth}

Tree growth is commonly observed by means of band dendrometers, which measure the change of tree circumference. The use of modern automatic band dendrometers delivers millimeter accuracy combined with fine temporal resolution that allows for detailed daily analysis of expansions and contractions schemes of tree stems. In combination with high resolution temporal sap flux devices, the daily swelling and shrinking can be related to assess water use patterns.

Correlating daily sap flux and diameter change data associated with concomitant phenological and environmental observations over wet and dry periods, will give insight into plant physiological behavior and structural adaptations to their environment.

\subsection{Meteorological and environmental measurements}

Water content reflectometers (CS616, Campbell Scientific, Inc., Logan, USA) were used to measure volumetric soil water content (SWC, \%) continuously at the three altitudes of sap flux measurements. Four probes were installed in a square of $4 \mathrm{~m} \mathrm{x} 4 \mathrm{~m}$ vertically at a depth of 0-30 $\mathrm{cm}$. Air temperature $\left({ }^{\circ} \mathrm{C}\right)$ and relative humidity $(\%)$ were measured at open conditions near the sap flux measurements at 860 and $1100 \mathrm{~m}$ asl. (CS215, Campbell Scientific, Inc., Logan, USA) and used to calculate vapor pressure deficit of the air (VPD, hPa). Air humidity data for the lowest study altitude had to be adopted from the mid elevation, as the actual measurements at $590 \mathrm{~m}$ asl. failed. Data was recorded every 30 seconds, averaged over 30 minutes and stored in a CR1000 data logger. 


\subsection{Author contribution}

Chapter 2: Tree responses to moisture fluctuations in a Neotropical dry forest as potential climate change indicators

Philipp Butz*, Volker Raffelsbauer*, Sophie Graefe, Thorsten Peters, Eduardo Cueva, Dirk Hölscher, Achim Bräuning

VR and PB equally contributed to the article (*). The experiment was designed by VR, SG and PB. VR, SG and PB planned, and VR and PB carried out the establishment of the plots. Data collection was done by VR (change of tree circumference) and PB (sap flux, meteorological), parts of meteorological data were provided by TP. Data analysis and processing was done by VR and PB with comments from SG, $\mathrm{DH}$ and $\mathrm{AB}$. The text was written by VR and PB with comments from SG, TP, EC, DH and AB.

Chapter 3: Tree water use patterns as influenced by phenology in a dry forest of southern Ecuador Philipp Butz*, Dirk Hölscher, Eduardo Cueva, Sophie Graefe

The study was designed by DH and SG. SG and PB planned, and PB carried out the establishment of the plots. Data collection (sap flux and meteorological) was done by PB, phenological information was provided by EC. Data analyzation and processing was done by PB with support from DH and SG. The text was written by PB with comments from DH, EC and SG.

Chapter 4: Water residence times in trees of a neotropical dry forest

Sophie Graefe*, Dongming Fang, Philipp Butz

SG and PB designed the study. Data collection was carried out by PB. Data processing and analysis was done by DF. The text was written by SG with comments from DF, PB and DH. 


\subsection{Affiliation of co-authors}

Dirk Hölscher

Eduardo Cueva

Sophie Graefe

Volker Raffelsbauer

Thorsten Peters

Achim Bräuning

Dongming Fang
Tropical Silviculture and Forest Ecology, Georg-August-University Göttingen, Göttingen, Germany

Nature and Culture International (NCI) Loja, Ecuador

Tropical Silvyculture and Forest Ecology, Georg-August-University, now at University of Kassel, Organic Plant Production and Agroecosystems Research in the Tropics and Subtropics

Institute of Geography, Friedrich-Alexander-University ErlangenNürnberg, Germany

Institute of Geography, Friedrich-Alexander-University ErlangenNürnberg, Germany

Institute of Geography, Friedrich-Alexander-University ErlangenNürnberg, Germany

State Key Laboratory of Subtropical Silviculture, Zhejiang Agriculture and Forestry University, Lin'an 311300, Zhejiang, China 


\subsection{References Chapter I}

Aguirre, Z., Linares-Palomino, R., Kvist, L.P., 2006. Especies lenosas y formaciones vegetales en los bosques estacionalmente secos de Ecuador y Peru. Arnaldoa 13, 324-350.

Allen, K.J., Dupuy, M., Gei, M.G., Hulshof, C., Medvigy, D., Pizano, C., Salgado-Negret, B., Smith, C.M., Trierweiler, A., Van Bloem, S.J., Waring, B.G., Xu, X., Powers, J.S., 2017. Will seasonally dry tropical forests be sensitive or resistant to future changes in rainfall regimes? Environ. Res. Lett. 12. doi: https://doi.org/10.1088/1748-9326/aa5968

Bastin, J.F., Berrahmouni, N., Grainger, A., Maniatis, D., Mollicone, D., Moore, R., Patriarca, C., Picard, N., Sparrow, B., Abraham, E.M., Aloui, K., Atesoglu, A., Attore, F., Bassüllü, Ç., Bey, A., Garzuglia, M., García-Montero, L.G., Groot, N., Guerin, G., Laestadius, L., Lowe, A.J., Mamane, B., Marchi, G., Patterson, P., Rezende, M., Ricci, S., Salcedo, I., Sanchez-Paus Diaz, A., Stolle, F., Surappaeva, V., Castro, R., 2017. The Extent of Forest in Dryland Biomes. Science 356. doi: https ://635-638. $10.1126 /$ science.aam6527

Bates, D., Maechler, M., Bolker, B., and Walker, S. (2015). Fitting linear mixed-effects models using lme4. J. Stat. Softw. 67, 1-48. doi: 10.18637/jss. v067.i01 (doi:10.1126/science.aam6527)

Bates, B.C., Kundzewicz, Z.W., Wu, S., Palutikof, J.P., 2008. Climate Change and Water. Technical Paper of the Intergovernmental Panel on Climate Change No. IV (IPCC) Secretariat, Geneva

Borchert, R., 1994a. Soil and Stem Water Storage Determine Phenology and Distribution of Tropical Dry Forest Trees. Ecology 75(5), 1437-1449.

Borchert, R., 1994b. Water Status and Development of Tropical Trees During Seasonal Drought. Trees 8, 115124.

Borchert, R., 1996. Phenology and flowering periodicity of neotropical dry forest species: evidence from herbarium collections. J. Trop. Ecol. 12, 65-80.

Borchert, R., 1999. Climatic Periodicity, Phenology, and Cambium Activity in Tropical Dry Forest Trees. IAWA Journal 20 (3), 239-247.

Borchert, R., Meyer, S.A., Felger, R.S., Porter-Bolland, L., 2004. Environmental control of flowering periodicity in Costa Rican and Mexican tropical dry forests. Global Ecology and Biogeography, (Global Ecol. Biogeogr.) 13, 409-425.

Borgogno, F., D’Odorico, P., Laio, F., Ridolfi, L., 2007. Effect of rainfall interannual variability on the stability and resilience of dryland plant ecosystems. Water Resour. Res. 43, 1-9. doi:10.1029/2006wr005314 
Brodribb, T.J., Holbrook, N.M., Gutiérrez, M.V., 2002. Hydraulic and photosynthetic coordination in seasonally dry tropical forest trees. Plant Cell Environ. 25, 1435-1444.

Calder, I.R., Narayanswamy, M.N., Srinivasalu, N.V., Darling, W.G., Lardner, A.J., 1986. Investigation into the use of deuterium as a tracer for measuring transpiration from eucalypts. Journal of Hydrology 84, 345351. doi:10.1016/0022-1694(86)90132-0

Carrasco, O.L., Bucci, S.J., Francescantonio, D.D., Lezcano, O.A., Campanello, P.I., Scholz, F.G., Rodríguez, S., Madanes, N., Cristiano, P.M., Hao, G.-Y., Holbrook, N.M., Goldstein, G., 2015. Water Storage Dynamics in the Main Stem of Subtropical Tree Species Differing in Wood Density, Growth Rate and Life History Traits. Tree Physiology 35(4). doi:10.1093/treephys/tpu087

Cueva, E., Acarró, J., 2011. Fénologia des arbres del bosque séco, reserva Laipuna, Ecuador. NCI Loja.

Chadwick, R., Good, P., Martin, G., Rowell, D.P., 2015. Large rainfall changes consistently projected over substantial areas of tropical land. Nat. Clim. Change 6, 177-181.

Chapotin, S.M., Razanameharizaka, J.H., Holbrook, N.M., 2006. Baobab Trees (Adansonia) in Madagascar Use Stored Water to Flush New Leaves but Not to Support Stomatal Opening before the Rainy Season. New Phytologist 169(3), 549-559.

Chave, J., Muller-Landau, H., Baker, T., Easdale, T., Steege, H., Webb, C., 2006. Regional and phylogenetic variation of wood density across 2456 neotropical tree species. Ecological Applications 16, 2356-2367.

Cruz, M., Quintana-Ascencio, P.F., Cayuela, L., 2017. Comment on "The extent of forest in dryland biomes." Technical Comment, Science 358. doi:10.1126/science.aao0369

Coster, C., 1927. Zur Anatomie und Physiologie der Zuwachszonen und Jahresbildung in den Tropen. Ann. Jard. Bot. Buitenzorg 37, 49-160.

D’Odorico, P., Laio, F., Ridolfi, L., 2005. Noise induced stability in dryland plant ecosystems. Proc. Natl Acad. Sci. USA 102 (10). 819-822. doi:10.1073/pnas.0502884102

Eamus, D., Prior, L., 2001. Ecophysiology of trees of seasonally dry tropics: comparisons among phenologies. Adv. Ecol. Res. 32, 113-197. doi:10.1016/S0065-2504(01)32012-3

Easterling, D.R., Meehl, G.A., Parmesan, C., Changnon, S.A., Karl, T.R., Mearns, L.O., 2000. Climate extremes: observations, modeling, and impacts. Science 289, 2068-2074.

Feng, M., Sexton, J. O., Huang, C., Anand, A., Channan, S., Song, X., Song, D., Kima, D., Noojipady, P., Townshenda, J.R., 2016. Earth science data records of global forest cover and change: Assessment of accuracy in 1990, 2000, and 2005 epochs. Remote Sensing of Environment 184, 73-85. doi:10.1016/j.rse.2016.06.012 
Furley, P.A., Proctor, J., Ratter, J.A., (eds) 1992. Nature and dynamics of forest-savanna boundaries. Chapman and Hall, London.

Gentry, A. H., 1995. Diversity and floristic composition of neotropical dry forests. Seasonally dry tropical forests (ed. By S. H. Bullock, H. A. Mooney and E. Medina), Cambridge University Press 146-194.

Granier, A., 1985. Une Nouvelle Méthode Pour La Mesure Du Flux de Sève Brute Dans Le Tronc Des Arbres. Ann. of Sci. 42(2), 193-200.

Greve, P., Orlowsky, B., Mueller, B., Sheffield, J., Reichstein, M., Seneviratne, S.I., 2014. Global assessment of trends in wetting and drying over land. Nat. Geosci. 7, 716-721.

Griffith, D.M., Lehmann, C.E.R., Strömberg, C.A.E., Parr, C.L., Pennington, R.T., Sankaran, M., Ratnam, J., Still, C.J., Powell, R.L., Hanan, N. P., Nippert, J.B., Osborne, C.P., Good, S.P., Anderson, T.M., Holdo, R.M., Veldman, J.W., Durigan, G., Tomlinson, K.W., Hoffmann, W.A., Archibald, S., Bond, W.J., 2017. Comment on "The extent of forest in dryland biomes." Technical Comment, Sciences 358. doi:10.1126/science.aao1309

Gitay, H., A. Suárez, and R. Watson, 2002. Climate Change and Biodiversity IPCC. IPCC report 24, 77.

Goldstein, G., Andrade, J.L., Meinzer, F.C., Holbrook, N.M., Cavelier, J., Jackson, P., 1998. Stem Water Storage and Diurnal Patterns of Water Use in Tropical Forest Canopy Trees. Environment 397-406. doi:10.1046/j.1365-3040.1998.00273.x

Hansen, M.C., Stehman, S.V., Potapov, P.V., 2010. Quantification of global gross forest cover loss. PNAS 107 (19). doi:10.1073/pnas.0912668107

Hansen, M.C., Potapov, P.V., Moore, R., Hancher, M., Turubanova, S.A., Tyukavina, A., Thau, D., Stehman, S.V., Goetz, S.J., Loveland, T.R., Kommareddy, A., Egorov, A., Chini, L., Justice, C.O., Townshend, J.R.G., 2013. High-Resolution Global Maps of 21st-Century Forest Cover Change. Science 342, 850854. http://www.ncbi.nlm.nih.gov/pubmed/24233722

Holbrook, N.M., Sinclair, T.R., 1992. Water Balance in the Arborescent Palm, Sabal Palmetto. I. Stem Structure, Tissue Water Release Properties and Leaf Epidermal Conductance. Plant, Cell \& Environment 15(4), 393-399.

Holbrook, N.M., Whitbeck, J.L., Mooney, H.A., 1995. Drought responses of neotropical dry forest trees. In Seasonally Dry Tropical Forests (eds Bullock, S. H., Mooney, H. A. and Medina, E.), Cambridge University Press, Cambridge, pp. 243-276.

Le Houérou, H.N., 2001. Biogeography of the arid steppeland north of the Sahara. Journal of Arid Environments 48 (2), 103-28. doi:10.1006/jare.2000.0679 
Linares-Palomino, R., Kvist, L.P., Aguirre-Mendoza, Z., Gonzales-Inca, C., 2009. Diversity and Endemism of Woody Plant Species in the Equatorial Pacific Seasonally Dry Forests. Biodiversity and Conservation 19(1), 169-185.

Lisi, C.S., Fo, M.T., Botosso, P.C., Roig, F.A., Maria, V.R., Ferreira-Fedele, L., Voigt, A.R., 2008. Tree-ring formation, radial increment periodicity, and phenology of tree species from a seasonal semi-deciduous forest in southeast Brazil. IAWA J. 29, 189-207.

Maestre, F.T., Salguero-Gomez, R., Quero, J.L., 2012. It is getting hotter in here: determining and projecting the impacts of global environmental change on drylands. Phil. Trans. R. Soc. B 367, 3062-3075. doi:10.1098/rstb.2011.0323

Mayaux, P., Holmgren, P., Achard, F., Eva, H., Stibig, H.J., Branthomme, A., 2005. Tropical forest cover change in the 1990s and options for future monitoring. Philosophical Transactions of the Royal Society B 360, 373-384.

Miles, L., Newton, A.C., DeFries, R.S., Ravilious, C., May, I., Blyth, S., Kapos V., Gordon, J.E., 2006. A Global Overview of the Conservation Status of Tropical Dry Forests. Journal of Biogeography 33(3), 491-505.

Mooney, H.A., Bullock S.H., Medina, E., 1995. Introduction: Seasonally dry tropical forests (ed. by S. H. Bullock, H. A. Mooney and E. Medina), Cambridge University Press, Cambridge 1-8.

Murphy, P.G., Lugo, A.E., 1986. Ecology of Tropical Dry Forest. Annual Review of Ecoloyg and Systematics $17,67-88$.

NAST, 2001. Climate Change Impacts on the United States: Potential Consequences of Climate Variability and Change (Foundation Report), (National Assessment Synthesis Team) Report for the US Global Change Research Program. Cambridge University Press, Cambridge, UK.

Naithani, K.J., Ewers, B.E., Pendall, E., 2012. Sap flux-scaled transpiration and stomatal conductance response to soil and atmospheric drought in a semi-arid sagebrush ecosystem. Journal of Hydrology 464-465, 176-185. doi:10.1016/j.jhydrol.2012.07.008

Ogburn, R.M., Edwards, E.J., 2010. 55 Advances in Botanical Research. The Ecological Water-Use Strategies of Succulent Plants. 1st ed. Elsevier Ltd. doi:10.1016/B978-0-12-380868-4.00004-1

Pennington, R.T, Prado, D.E., Pendry, C.A., 2000. Neotropical Seasonally Dry Forests and Quaternary Vegetation Changes. Journal of Ecology 27, 261-273.

Pennington, R.T., Lavin M., Oliveira, A., 2009. Woody Plant Diversity, Evolution, and Ecology in the Tropics: Perspectives from Seasonally Dry Tropical Forests. Annual Review of Ecology Evolution and Systematics 40, 437-457. 
Poorter, L., McNeil, A., Hurtado, V.H., Prins H.H.T., Putz, F.E., 2014. Bark traits and life-history strategies of tropical dry- and moist forest trees. Funct. Ecol. 28, 232-242. doi:10.1111/1365-2435.12158

Pucha-Cofrep, D., Peters, T., Bräuning, A., 2015. Wet season precipitation during the past 120 years reconstructed from tree rings of a tropical dry forest in Southern Ecuador. Global and Planetary Change $133,65-78$.

Reich, P.B., Borchert, R., 1984. Water Stress and Tree Phenology in a Tropical Dry Forest in the Lowlands of Costa Rica. Journal of Ecology 72(1), 61-74.

Rivera, G., Elliott, S., Caldas, L.S., Nicolossi, G., Coradin, V. T. R., Borchert, R., 2002. Increasing day-length induces spring flushing of tropical dry forest trees in the absence of rain. Trees, 16, 445-456.

Rosell, J.A., Gleason, S., Méndez-Alonzo, R., Chang Y., Westoby, M., 2014. Bark functional ecology: evidence for tradeoffs, functional coordination, and environment producing bark diversity. New Phytol. 201, 486497. doi:10.1111/nph.12541

Rozendaal, D.M.A., Zuidema, P.A., 2011. Dendroecology in the tropics: a review. Trees 25, 3-16. doi:10.1007/s00468-010-0480-3

Scholz, F.C. Bucci, S.J., Goldstein, G., Meinzer, F.C., Franco A.C., Miralles-Wilhelm, F., 2008. Temporal Dynamics of Stem Expansion and Contraction in Savanna Trees: Withdrawal and Recharge of Stored Water. Tree Physiology 28(3), 469-480.

Schöngart, J., Piedade, M.T.F., Ludwigshausen, S., Horna V., Worbes, M., 2002. Phenology and stem-growth periodicity of tree species in Amazonian floodplain forests. J. Trop. Ecol. 18, 581-597. doi:10.1017/ S0266467402002389

Schwinning, S., Ehleringer, J.R., 2001. Water use trade-offs and optimal adaptations to pusle driven ecosystems. J. Ecol. 89, 464-480. doi:10.1046/j.1365-2745.2001.00576.x

Seddon, A.W., Macias-Fauria, M., Long, P.R., Benz D., Willis, K.J., 2016. Sensitivity of Global Terrestrial $\begin{array}{llll}\text { Ecosystems to } & \text { Climate }\end{array}$ http://www.ncbi.nlm.nih.gov/pubmed/26886790

Sierra, R. 1999. Propuesta Preliminar de un Sistema de Clasificacion de Vegetacion para el Ecuador Continental. Proyecto INEFAN, GEFBIRG y EcoCiencia, Quito, Ecuador.

Singh, K.P. Kushwaha, C.P., 2016. Deciduousness in tropical trees and its potential as indicator of climate change: a review. Ecol. Indic. 69, 699-706. 
Spannl, S., Ganzhi, O., Peters, T., Bräuning, A., 2013. Tree growth under climatic and trophic forcing - A nutrient manipulation experiment in Southern Ecuador. Conference: TRACE (Vol. 11) - Tree Rings in Archaeology, Climatology and Ecology.

Spannl, S., Volland, F., Pucha, D., Peters, T., Bräuning, A., 2016. Climate variability, tree increment patterns and ENSO-related carbon sequestration reduction of the tropical dry forest species Loxopterygium huasango of Southern Ecuador. Trees 30, 1245-1258.

Tyree, M.T. Yang, S., 1990. Water-Storage Capacity of Thuja, Tsuga and Acer Stems Measured by Dehydration Isotherms - The Contribution of Capillary Water and Cavitation. Planta 182(3), 420-426.

UNEP (United Nations Environment Programme), 1997. World atlas of desertification. 2ED. UNEP, London.

Worbes, M., 1995. How to measure growth dynamics in tropical trees: a review. IAWA J. 16, 337-351.

Worbes, M., 2002. One hundred years of tree-ring research in the tropics - a brief history and an outlook to future challenges. Dendrochronologia 20, 217-231. doi:10.1078/1125-7865-00018

Worbes, M., Blanchart, S., Fichtler, E., 2013. Relations between water balance, wood traits and phenological behavior of tree species from a tropical dry forest in Costa Rica - a multifactorial study. Tree Physiol. 33, 527-536. doi:10.1093/treephys/tpt028 


\section{Chapter 2}

\section{Tree responses to moisture fluctuations in a neotropical dry forest as potential climate change indicators}

Philipp Butz ${ }^{1 *}$, Volker Raffelsbauer ${ }^{2 * \dagger}{ }^{\dagger}$, Sophie Graefe ${ }^{1}$, Thorsten Peters ${ }^{2}$, Eduardo Cueva ${ }^{3}$, Dirk Hölscher ${ }^{1}$, Achim Bräuning ${ }^{2}$

* The authors contributed equally to this work

${ }^{1}$ Tropical Silviculture and Forest Ecology, Georg-August-University Göttingen, Germany

${ }^{2}$ Institute of Geography, Friedrich-Alexander-University Erlangen-Nürnberg, Germany

${ }^{3}$ Nature and Culture International, Loja, Ecuador

${ }^{\dagger}$ Correspondence to: Volker Raffelsbauer, Institute of Geography, Friedrich-Alexander-University Erlangen-Nürnberg, Germany, Email address: volker.raffelsbauer@fau.de

Published in: Ecological Indicators, December 2017| Volume 83 | Pages 559-571

doi:10.1016/j.ecolind.2016.11.021

Chapter version: as published in Ecological Indicators 


\section{Abstract Chapter 2}

Trees in tropical dry forests (TDFs) have manifold drought coping strategies including succulence of different plant organs, wood anatomical traits and leaf phenology. As water availability to plants is the limiting factor for physiological activity, changes in precipitation patterns are assumed to have strong influences on tree phenology, growth and water turnover. Our objectives were to assess patterns in leaf phenology, radial stem circumference changes and sap flux responses to fluctuating moisture regimes of selected species. Based on these findings we evaluated the potential suitability as indicator species for climate change effects. The study was implemented at different elevational positions in a submontane dry forest of southern Ecuador. Annual rainfall is $600 \mathrm{~mm}$ with an eight months' dry period; moisture availability slightly increases with altitude because of moist air coming from the Pacific. At three altitudes, we studied the tree species Ceiba trichistandra (leaf deciduous, stem succulent), Eriotheca ruizii (leaf deciduous, root succulent) and Erythrina velutina (leaf deciduous). Reversible stem swelling and shrinking was observed for all three species during the whole study period and at all positions at the altitudinal gradient. However, it was most pronounced and sensitive in the stem succulent $C$. trichistandra and at the lowest (driest) position. C. trichistandra flushed leaves at dry season intermittent rain events, and from dry to wet season leaf out was earlier, and in this period sap flux was high while stem circumference decreased. Length of the leaved periods of all species increased with altitude. Thus, clear differences among species, topographic positions, radial growth and tree water use patterns are revealed; especially $C$. trichistandra responded very sensitive to fluctuating moisture regimes with leaf phenology, sap flux and stem diameter variations, and can be regarded as a sensitive indicator for assessing climatic variations.

Keywords: Ecuador, elevation gradient, phenology, sap flux, seasonality, tree indicator 


\subsection{Introduction}

Tropical drylands and seasonally dry forests host around $20 \%$ of the number of major centers of plant biodiversity and endemism (Maestre et al., 2012; Estrada-Medina et al., 2013). Tropical dry forests (TDFs) are composed of trees exhibiting different drought coping mechanisms, with a majority of deciduous tree species and a small number of evergreens (Bullock et al., 1995). A distinct seasonality in rainfall with the occurrence of a prominent dry season of at least six months duration and monthly mean precipitation below $100 \mathrm{~mm}$ is the decisive factor controlling phenological phases, seasonal tree growth rhythms and water consumption of trees (Sayer and Newbery, 2003; Mayle, 2004; Krepkowski et al., 2011; Spannl et al., 2016). However, trees' responses to the seasonality of climatic factors vary considerably between regions and tree species across the tropics (Wagner et al., 2014, 2016). Besides regional climate, local site conditions related to topography (e.g. slope angle, exposition, altitude) have an influence on moisture availability for trees. In tropical South America, the Tumbesian dry forests cover a vast territory of approx. $87,000 \mathrm{~km}^{2}$ of the equatorial Pacific region of Ecuador and Peru; however, they have thus far received little scientific attention (Espinosa et al., 2011). Previous research in TDFs mainly focused on tree growth dynamics (e.g. Volland-Voigt et al., 2009, 2011) or succession dynamics and conservation aspects (Dupuy et al., 2012; Pineda-Garcia et al., 2013; Buzzard et al., 2015). Detailed knowledge on relations between climatic conditions and tree water-use is scarce (Mendivelso et al., 2016), the same holds true for drought coping mechanisms of co-existing tree species with distinct physiological and phenological traits and resulting tree growth patterns. Such information however is needed to derive better knowledge on the provisioning of ecosystem services, possible climate changerelated threats for dry forest ecosystems, and to choose best options for sustainable land use management (Knoke et al., 2014).

Trees growing in drought-stressed environments developed different strategies to cope with seasonal water shortage, like e.g. drought avoiders and drought tolerant species (Gebrekirstos et al., 2006). Tree physiological and wood anatomical traits and phenological behavior determine the degree of water stress experienced by different tree species. Several studies conducted in dry forests examined leaf traits like stomatal conductance, turgor, and water potential (Brodribb and Holbrook, 2003; Brodribb et al., 2003; Bucci et al., 2005; Fu et al., 2012), indicating that plant water use is usually controlled by a combination of plant physiological and architectural traits. Wood saturated water content, which is inversely related to wood density, buffers the impact of seasonal drought, and enables flowering and flushing during the dry season (Borchert, 1994; Stratton et al., 2000). Seasonal changes in stem diameter can thus be used as an in-direct measure of changes in tree water status (Borchert, 1994). Interactions between transpiration, stem water storage and environmental factors result in species-specific patterns of phenology and tree water use (Singh and Kushwaha, 2016), and have a high ecological significance in drought stressed environments. We studied tree responses to seasonal changes and inter-seasonal fluctuating moisture conditions in a dry tropical forest in southern Ecuador. Our objectives were to 
assess response patterns in leaf phenology, stem diameter variations, tree growth dynamics, and sap flux to fluctuating moisture conditions for different tree species and at different sites. The main aim of our study was to identify tree species that are sensitive indicators for climatic variations throughout the seasons, and which could be used to monitor climate change effects in TDFs.

\subsection{Material and Methods}

\subsubsection{Study area and tree species}

The study was conducted in the Laipuna Forest Reserve in southern Ecuador, which belongs to the Tumbesian dry forest ecoregion. The region is characterized by hilly terrain and altitudes of 600-1450 $\mathrm{m}$ asl. Annual precipitation strongly varies inter-annually and ranges between 350 and $800 \mathrm{~mm}$ (Figure 2.1). Moisture availability increases with elevation due to an increase in precipitation and a decrease of temperature and related atmospheric vapor pressure deficit (VPD). Annual precipitation distribution shows a distinctive dry season from June to December, but even during the wet season which lasts from January to May, shorter drought periods are common (Pucha-Cofrep et al., 2015). Moisture bringing air masses during the wet season originate mainly from the Pacific Ocean, and precipitation events mostly occur during night times (Spannl et al., 2016). Annual mean temperature is $23.7{ }^{\circ} \mathrm{C}$ and shows little variability throughout the year (Figure 2.1). To study tree responses to climatic and site conditions along an elevation gradient, three study plots were established at altitudes of 670, 860 and $1100 \mathrm{~m}$ asl. We selected three tree species (Eriotheca ruizii (K. Schum.) A. Robyns (Malvaceae), Ceiba trichistandra (A. Gray) Bakh. (Malvaceae), Erythrina velutina Willd. (Fabaceae)) that are characteristic for the South Ecuadorian dry forest and belong to the most abundant species. Importance Value Indices (IVI = relative abundance + relative dominance + relative frequency) according to Curtis and McIntosh (1951) were 48.3 for E. ruizii, 37.4 for C. trichistandra, and 24.3 for E. velutina in this forest (Homeier, unpublished). All three species are canopy trees with a large ecological amplitude, only the abundance of $C$. trichistandra decreases towards higher elevation. C. trichistandra and E. ruizii are endemic to the region, whereas E. velutina shows a wider distribution and is commonly used in reforestation projects, e.g. Brazil (Souza et al., 2016). All three species are deciduous but might differ in their drought coping strategies, which makes them excellent study objects as indicator species, i.e. E. ruizii is a root succulent, C. trichistandra is a stem succulent, and E. velutina shows a corked bark. C. trichistandra starts to flush leaves in the late dry season before the onset of the wet season; the other two species start bud break after the first pronounced rain events during the early wet season. Tree behavior during four distinct climatic periods (dry season, early wet season, middle of wet season and late wet season), which are distinguished by different levels of precipitation, vapor pressure deficit and soil moisture, was examined from March 2014 to June 2015. Leaf phenology was assessed through hemispherical photography during transition phases from wet to dry in April-June 2014 and from dry to wet in December-February 2015 
on all plots. Therefore, a 1 ha systematic sampling grid $(30 \times 30 \mathrm{~m})$ was laid over the center of each plot using ArcGIS, resulting in nine sampling points per altitude. Photos were taken every four days during the early morning $(6: 00-9: 00 \mathrm{am})$ or late afternoon $(4: 00-6: 00 \mathrm{pm})$ in order to avoid strong direct sunlight in the camera. All sampled individuals were covered by the hemispherical photographs. The images were processed with CAN EYE version 5.0 (INRA, France). Canopy coverage was estimated every 15 days by visual assessment from November 2013 until October 2015 and categorized into groups from 0 to $25 \%, 26-50 \%, 51-75 \%, 76-100 \%$ and fully leafed according to Fournier (1974).

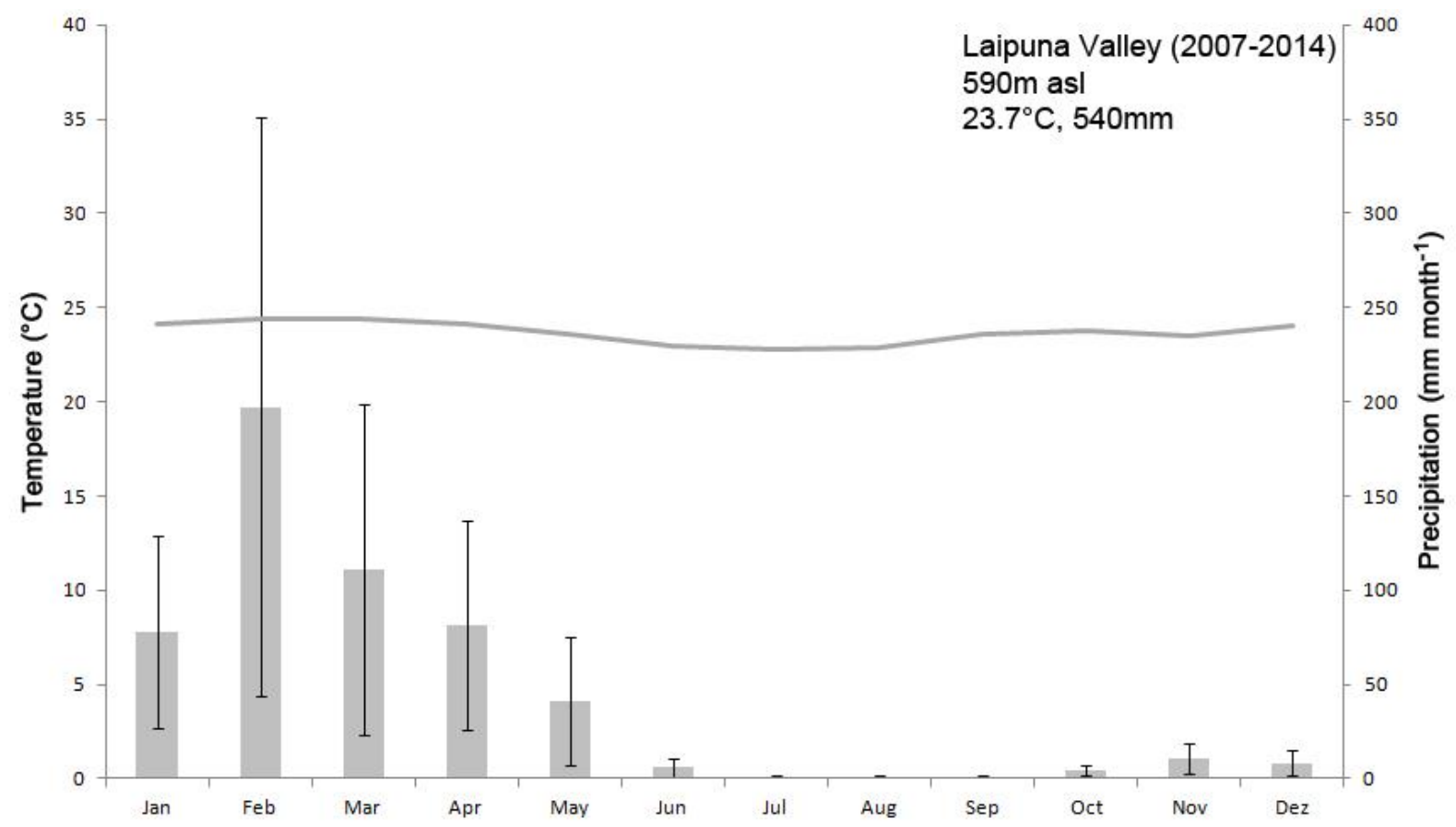

Figure 2.1 Climate diagram of the study area, error bars show SD.

\subsubsection{Soil moisture and meteorological measurements}

Volumetric soil water content (hereafter referred to as soil water content, SWC, \%) was continuously measured at all three plots using TDR (time domain reflectometry) probes (CS616, Campbell Scientific, Inc., Logan, UT, USA). At the center of each plot four probes were installed in a rectangular spacing by $4 \times 4 \mathrm{~m}$ at a depth of $30 \mathrm{~cm}$. Air temperature and relative humidity (CS215, Campbell Scientific, Inc., Logan, UT, USA) were measured $2 \mathrm{~m}$ above the ground at the study sites at 860 and $1100 \mathrm{~m}$ asl. Data were recorded every $30 \mathrm{~s}$, averaged over $30 \mathrm{~min}$ and stored in a CR1000 data logger (Campbell Scientific). Meteorological data for the lowest study site was taken from the nearby climate station (THIES Climate, Germany), located $700 \mathrm{~m}$ to the SSE at $590 \mathrm{~m}$ asl. in open field. 


\subsubsection{Sap flux measurements,}

Sap flux density was continuously measured from April 2014 to June 2015 on four tree individuals of each species at each altitude. The selected tree individuals had to be within a range of $20 \mathrm{~m}$ from the plot centers to assure sufficient signal power for the sap flux measurements. Apart from these restrictions, individuals were chosen randomly.

Thermal dissipation probes after Granier (1987) were used, which consisted of a pair of probes with a diameter of $2 \mathrm{~mm}$ and a length of $20 \mathrm{~mm}$. Every tree was equipped with two sensors (one facing north, one facing south) at a height of $1.3 \mathrm{~m}$ above ground in the outermost xylem. Sensors were covered by Styrofoam boxes and reflective foil to protect against physical impacts, solar radiation and water. The upper probe of the sensor pair was continuously heated through a heating wire that was supplied with a constant power source of $120 \mathrm{~mA}$. The temperature difference between the two probes was measured every $30 \mathrm{~s}$ and averages were stored every $30 \mathrm{~min}$ (CR1000 data logger and AM 16/32 Multiplexer, Campbell Scientific, Inc, Logan, UT, USA). Temperature differences were further converted to sap flux density $\left(\mathrm{J}_{\mathrm{s}}\right.$ in $\left.\mathrm{g} \mathrm{cm}^{-2} \mathrm{~h}^{-1}\right)$ according to the empirically derived equation of Granier (1987). If sap flux data for single sensors were incomplete during a day due to power shortage or maintenance, the specific sensor did not enter the analysis on the respective day. Installations at the lowest plot were under maintenance in the beginning of February 2015 for two weeks; hence no data was available during that time. Short power shortages occurred randomly during the measurement period.

\subsubsection{Dendrological measurements}

Circumferential change was measured with logging band dendrometers with a built-in thermometer (DRL26, EMS Brno) on the same trees that were equipped with thermal dissipation probes. In the case of $E$. ruizii and E. velutina dendrometers were attached at breast height on the stems. However, stems of $C$. trichistandra form characteristic buttress-roots; hence we mounted the dendrometers at approximately two meters stem height to ensure that the bands enclose the complete stem circumference. In some cases it was necessary to carefully smooth the bark before installation.

\subsubsection{Wood and bark traits}

All studied species show a diffuse porous wood anatomy. Average wood density of E. ruizii $(0.47 \mathrm{~g}$ $\left.\mathrm{cm}^{-3}\right)$ was higher than that of $C$. trichistandra $\left(0.26 \mathrm{~g} \mathrm{~cm}^{-3}\right)$ and E. velutina $\left(0.2 \mathrm{~g} \mathrm{~cm}^{-3}\right)$ (Zanne et al., 2009) (Table 2.1). To determine bark thickness, 30 wood cores per species were collected with Mora increment borers ( $5 \mathrm{~mm}$ wide, 150-600 mm long). Bark thickness differed significantly between species ( $\mathrm{p}<0,001$, Welch) and showed means of $1.0 \pm 0.2 \mathrm{~mm}$ for C. trichistandra, $3.9 \pm 0.8 \mathrm{~mm}$ for E. velutina, and $22.3 \pm 3.9 \mathrm{~mm}$ for E. ruizii, respectively. While bark of the first two species showed no shrinkage 
after drying, bark of E. ruizii contracted strongly during drying. Increment cores of $C$. trichistandra exhibited strong shrinkage and deformation after desiccation.

\subsubsection{Statistical analysis}

The relationships between sap flux density, change in stem circumference and environmental variables (SWC, VPD and precipitation) were tested with linear correlations. All assumptions for linear correlations were tested and fulfilled. All statistical analyses were conducted with RStudio version 3.2.2 (R Development Core Team, 2015).

Table 2.1 Characteristics of tree species and trees studied (mean \pm SE), wood density taken from Zanne et al., 2009.

\begin{tabular}{|c|c|c|c|c|c|c|c|}
\hline Species & $\begin{array}{l}\text { Drought } \\
\text { coping }\end{array}$ & $\begin{array}{l}\text { Wood } \\
\text { porosity }\end{array}$ & $\begin{array}{l}\text { Wood density } \\
\left(\mathrm{g} \mathrm{cm}^{-3}\right)\end{array}$ & $\begin{array}{l}\text { Crown } \\
\text { position }\end{array}$ & $\begin{array}{l}\text { Diameter } \\
(\mathrm{cm})\end{array}$ & $\begin{array}{l}\text { Height } \\
\text { (m) }\end{array}$ & $\mathrm{n}$ \\
\hline $\begin{array}{l}\text { Ceiba } \\
\text { trichistandra }\end{array}$ & $\begin{array}{l}\text { Stem } \\
\text { succulent, } \\
\text { deciduous }\end{array}$ & $\begin{array}{l}\text { Diffuse } \\
\text { porous }\end{array}$ & 0.26 & $\begin{array}{l}\text { Canopy, } \\
\text { emergent }\end{array}$ & $77.9 \pm 7.7$ & $15.5 \pm 1.3$ & 12 \\
\hline $\begin{array}{l}\text { Eriotheca } \\
\text { ruizii }\end{array}$ & $\begin{array}{l}\text { Root } \\
\text { succulent, } \\
\text { deciduous }\end{array}$ & $\begin{array}{l}\text { Diffuse } \\
\text { porous }\end{array}$ & 0.47 & Canopy & $39.3 \pm 2.4$ & $13.4 \pm 0.9$ & 12 \\
\hline $\begin{array}{l}\text { Erythrina } \\
\text { velutina }\end{array}$ & $\begin{array}{l}\text { Deciduou } \\
\mathrm{s}\end{array}$ & $\begin{array}{l}\text { Diffuse } \\
\text { porous }\end{array}$ & 0.2 & Canopy & $27.8 \pm 3.6$ & $9.9 \pm 0.9$ & 12 \\
\hline
\end{tabular}

\subsection{Results}

\subsubsection{Seasonality of leaf phenology and changes in stem circumference}

At the beginning of the study period (April 2014) leaf shedding started in the early dry season due to low rainfall in the previous month. Stem circumference of $C$. trichistandra and E. ruizii decreased during this period of declining SWC, until an unusual rain event occurred at the beginning of May, which lasted for several days. This led to stem-rehydration of the completely defoliated trees (Figure 2.2). With the advancing dry season marked differences between the studied tree species became evident. Whereas $C$. trichistandra and E. ruizii showed a continuous decrease in stem circumference, E. velutina maintained a stable circumference (Figure 2.2). Bud break in C. trichistandra occurred in mid-December, which is 
about four weeks before the onset of the wet season. Its leaves were fully flushed 2-3 weeks after bud break. During this time stem circumference decreased sharply until the first strong rain events took place (end of January 2015; Figure 2.2). In E. ruizii and E. velutina bud break occurred at the beginning of the first heavy rains in mid-January 2015, and leaves were fully flushed 2-3 weeks later (Figure 2.3). During the wet season, when all species showed maximum foliage, C. trichistandra and E. ruizii displayed several alternating periods of strong diel stem circumference variations from January to April 2015, which was strongly related to precipitation patterns. E. velutina generally showed minor amplitudes of stem circumference variations in the first half of the wet season, but a sharp increase in stem circumference in the second half of the wet season. E. velutina and C. trichistandra flowered in the middle and at the very end of the wet season, respectively. Leaf shedding of all species started in the early dry season in mid-June. For C. trichistandra and E. ruizii, defoliation was followed by an increase in circumference caused by rehydration of the stems. This process of rehydration was visible in both study years, as well as the early bud break of $C$. trichistandra before the occurrence of the first rains. 


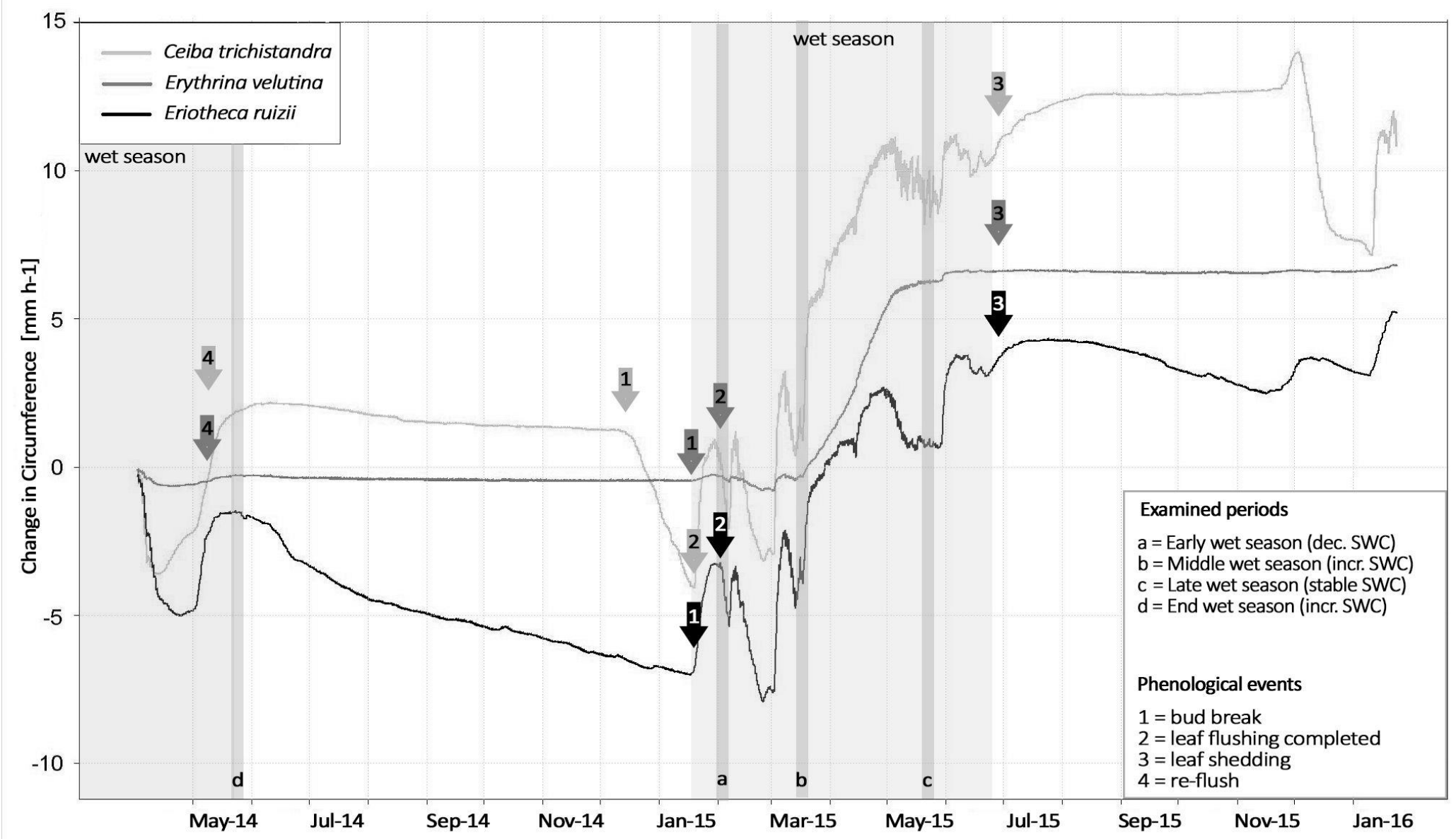

Figure 2.2 Mean cumulative stem diameter for E. ruizii, C. trichistandra and E. velutina calculated from 12 individuals each during the study period from April 2014 to January 2016. Numbered arrows indicate bud break, leaf flushing, leaf shedding and re-flushing after a rain event. Light grey bars indicate the length of the wet season, small dark grey bars indicate the examined periods characterized by distinct soil water conditions 


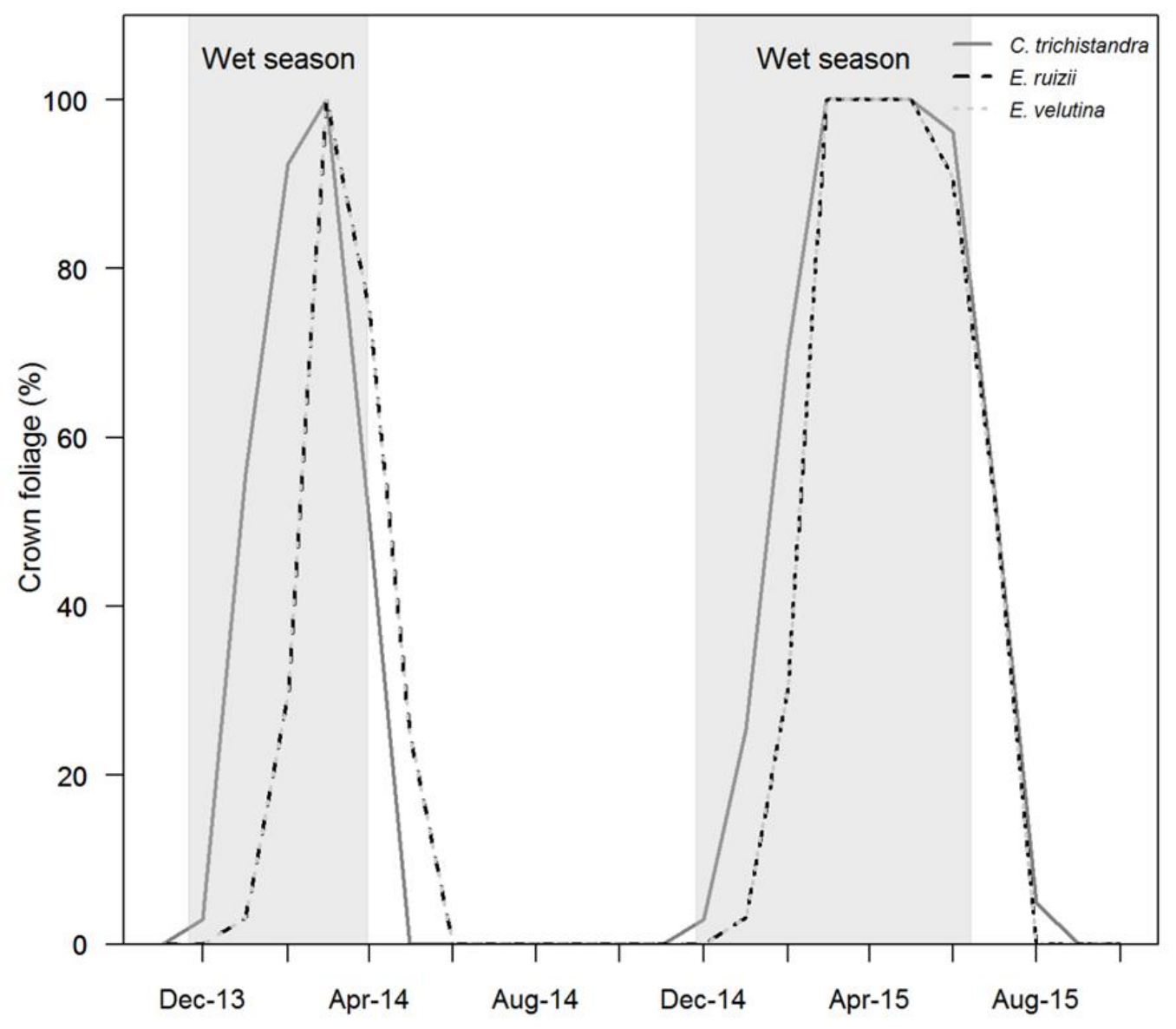

Figure 2.3 Change of foliation for C. trichistandra, E. ruizii and E. velutina during two consecutive years within the study period. The course of foliation for E. ruizii and E. velutina was observed to be the same over the course of the study. 


\subsubsection{Influence of different climatic periods on tree behavior along the elevational gradient}

During the early wet season, sap flux densities of $C$. trichistandra were low at the lowest study site, and followed daily variations in VPD $\left(\mathrm{R}^{2}=0.75 ; \mathrm{p}<0.001\right.$, Table 2.2), whereas diel changes in stem circumference were pronounced and maximum values followed the gradual decline in SWC (Figure 2.4) $\left(R^{2}=0.82, p<0.001\right.$, Table 2.2). By that time the other two species were still in the leaf flushing process, and mean canopy coverage of $30 \%$ was recorded. Changes in stem circumference followed SWC in both species $\left(R^{2}=0.93, p<0.001\right.$, Table 2.2). The partly increasing error bars for $\Delta$ Circumference result from the fact that the individual stem sizes do not have an everyday common baseline like the sap flux data and hence stem circumferences may diverge during consecutive days.

At the highest altitude, a similar leaf development pattern was observed. Daily variations in stem circumference showed minimum values during daytime, but increased during nighttime; no long-term decrease in circumference was detected. SWC was high with a slight decrease over the displayed period (Figure 2.4). Sap flux density of $C$. trichistandra was higher than at the lowest elevation and followed diurnal courses of $\operatorname{VPD}\left(\mathrm{R}^{2}=0.72 ; \mathrm{p}<0.001\right.$, Table 2.2). The displayed sap flux patterns of $E$. velutina and $E$. ruizii were comparable to fully leafed trees and mainly driven by $\operatorname{VPD}\left(\mathrm{R}^{2}=0.57\right.$ and $\mathrm{R}^{2}=0.52$, $\mathrm{p}<0.001$ respectively, Table 2.2). 


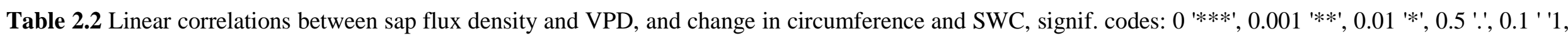
degrees of freedom $>200$.

\begin{tabular}{|c|c|c|c|c|c|c|c|c|c|}
\hline & \multicolumn{3}{|c|}{ C. trichistandra } & \multicolumn{3}{|c|}{ E. ruizii } & \multicolumn{3}{|c|}{ E. velutina } \\
\hline & $670 \mathrm{~m}$ & $860 \mathrm{~m}$ & $1100 \mathrm{~m}$ & $670 \mathrm{~m}$ & $860 \mathrm{~m}$ & $1100 \mathrm{~m}$ & $670 \mathrm{~m}$ & $860 \mathrm{~m}$ & $1100 \mathrm{~m}$ \\
\hline $\begin{array}{l}\mathbf{J}_{\mathbf{s}} \sim \mathbf{V P D} \\
\text { Start wet season (9.2.) }\end{array}$ & $0.75 * * *$ & $0.69 * * *$ & $0.72 * * *$ & n.a. & $0.58 * * *$ & $0.52 * * *$ & n.a. & $0.60 * * *$ & $0.57 * * *$ \\
\hline Middle wet season (6.3.) & $0.57 * * *$ & $0.58 * * *$ & $0.68 * * *$ & $0(0)$ & $0.37 * * *$ & $0.59 * * *$ & $0.50 * * *$ & $0.55 * * *$ & $0.67 * * *$ \\
\hline Middle wet season (16.3) & $0.26 * * *$ & $0.73 * * *$ & $0.66^{* * *}$ & $0.24 * * *$ & $0.39 * * *$ & $0.60 * * *$ & $0.20 * * *$ & $0.43 * * *$ & $0.34 * * *$ \\
\hline End of wet season (20.5.) & $0.68 * * *$ & $0.89 * * *$ & $0.91 * * *$ & $0.60 * * *$ & $0.86 * * *$ & $0.77 * * *$ & $0.66 * * *$ & $0.93 * * *$ & $0.75^{* *}$ \\
\hline \multicolumn{10}{|l|}{$\Delta$ Circ. $\sim$ SWC } \\
\hline Start wet season (9.2.) & $0.82 * * *$ & $0.83 * * *$ & $0.31 * * *$ & $0.93 * * *$ & $0.61 * * *$ & $0.13 * * *$ & $0.93 * * *$ & $0.83 * * *$ & $0.69 * * *$ \\
\hline Middle wet season (6.3.) & $0.56 * * *$ & $0.33 * * *$ & 0.04 & 0.02 & 0.04 & $0.18 * * *$ & $0.52 * * *$ & $0.36 * * *$ & $0.17 * * *$ \\
\hline Middle wet season (16.3) & $0.86 * * *$ & $0.82 * *$ & $0.77 * * *$ & $0.81 * * *$ & $0.81 * * *$ & $0.78 * * *$ & $0.77 * * *$ & $0.83 * * *$ & $0.85 * * *$ \\
\hline End of wet season (20.5.) & $0.70 * * *$ & $0.21 * * *$ & 0.05 & $0.62 * * *$ & $0.61 * * *$ & 0.05 & $0.18 * * *$ & 0 & 0.1 \\
\hline
\end{tabular}


In the middle of the wet season with decreasing SWC (Figure 2.5), C. trichistandra and E. ruizii responded quickly to short (two weeks) dry periods. From wet season maximum values, stem circumference strongly decreased during daytimes when sap flux was high. During nights, stem circumferences increased until sunrise. The magnitude of the described effects was influenced by soil water availability and therefore most pronounced at $670 \mathrm{~m}$ asl. and diminished with increasing altitude. However, while $C$. trichistandra responded within two days after the last rain event, E. ruizii responded with a delay of five days. For E. velutina sap flux only slightly decreased, and stem circumference remained constant. When such dry spells were interrupted by rain events (Figure 2.6, middle of wet season, increasing SWC), C. trichistandra and E. ruizii responded with pronounced stem diameter increase caused by rehydration, especially at the two lowest elevations. Here we found an increase in the relation between SWC and stem diameter variation (for both species $\mathrm{R}^{2}>0.8, \mathrm{p}<0.001$, Table 2.2). The time-lag between rain-event and rehydration of the trunk was approximately $4 \mathrm{~h}$. The increase in stem circumference was highest during night times when sap flux density was low. During daytimes, stem circumferences of $C$. trichistandra and $E$. ruizii remained stable or even declined, as sap flux density was high (Figure 2.7). In contrast, E. velutina was not affected by the short dry period and maintained a stable circumference. $C$. trichistandra and E. ruizii showed high correlations for sap flux density and VPD at $1100 \mathrm{~m}$ asl. $\left(\mathrm{R}^{2}=0.66\right.$, and $\mathrm{R} 2=0.60, \mathrm{p}<0.001$, respectively, Table 2.2). When rainfall considerably declined at the end of the wet season (Figure 2.7), all species showed reduced sap flux rates at the lowest site. The most pronounced decrease in sap flux density was observed at $670 \mathrm{~m}$ asl. for all species (E. velutina $50 \%$, E. ruizii $40 \%$ and C. trichistandra 20\%). At all elevations sap flux density and VPD were highly correlated in all species $\left(\mathrm{R}^{2}>0.60, \mathrm{p}<0.001\right.$, Table 2.2). Changes in circumference for $C$. trichistandra as well as for $E$. ruizii were influenced by $\mathrm{SWC}\left(\mathrm{R}^{2}=0.70, \mathrm{p}<0.001\right.$ and $R^{2}=0.61, p<0.001$, respectively, Table 2.2). At the highest elevation a higher SWC was observed, and sap flux was not reduced for any species (Figure 2.7). 


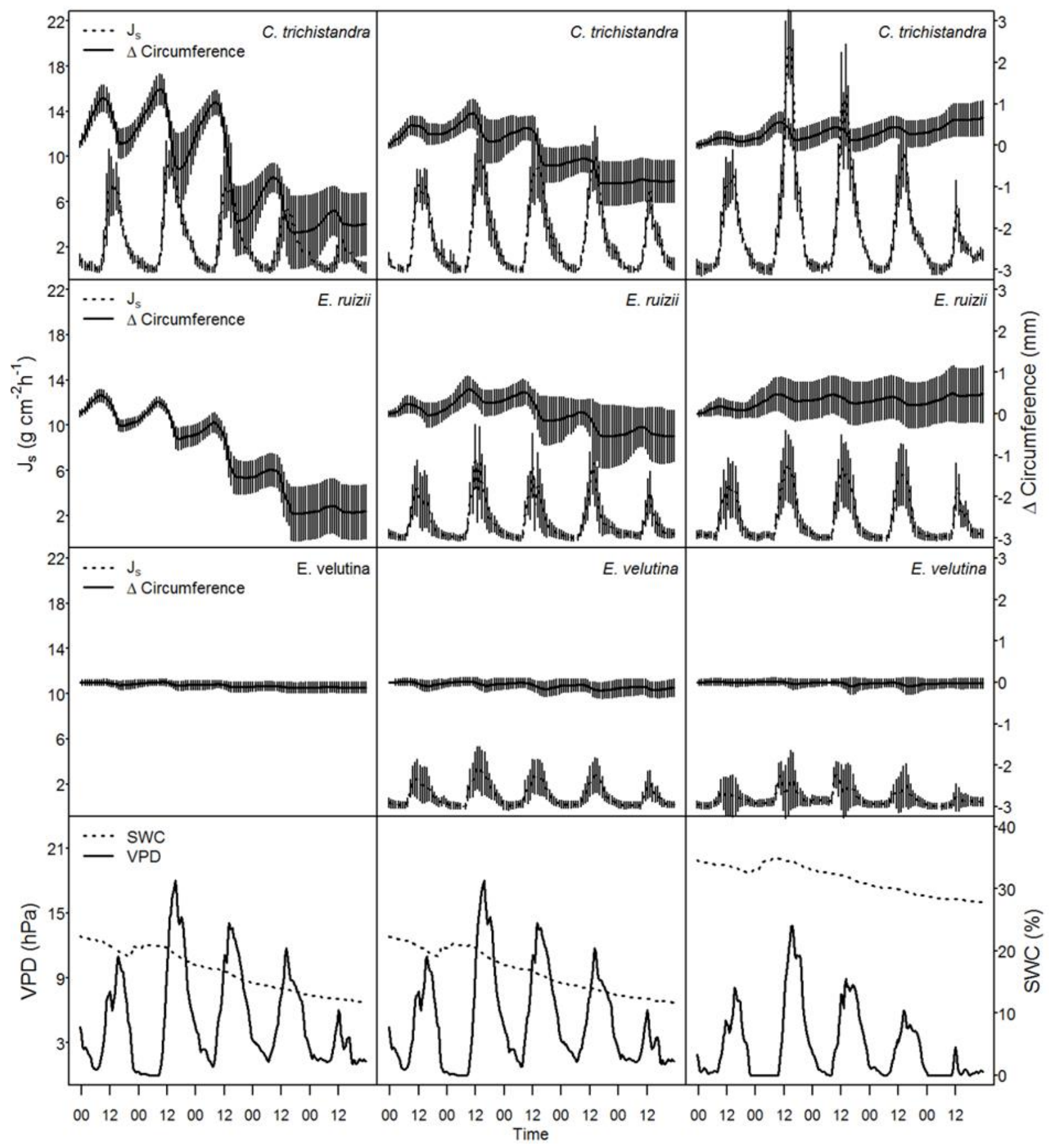

Figure 2.4 Start of wet season, course over five consecutive days (9.2.-13.2.2015) of diel change in stem circumference ( $\Delta$ Circumference measurements, solid line) and sap flux density $\left(\mathrm{J}_{\mathrm{s}}\right.$ measurements, dashed line) for $\mathrm{n}=4$ individuals per species and plot. Vapor pressure deficit (VPD, solid line) and volumetric soil water content (SWC, dashed line) is shown for all three elevations, medium precipitation $(30 \mathrm{~mm})$ was recorded earlier on Feb.7th, $2 \mathrm{~mm}$ precipitation on Feb. 9th, followed by dry conditions. Missing data for E. ruizii and E. velutina at $670 \mathrm{~m}$ asl. due to maintenance during this observation period. Error bars represent standard deviation. 


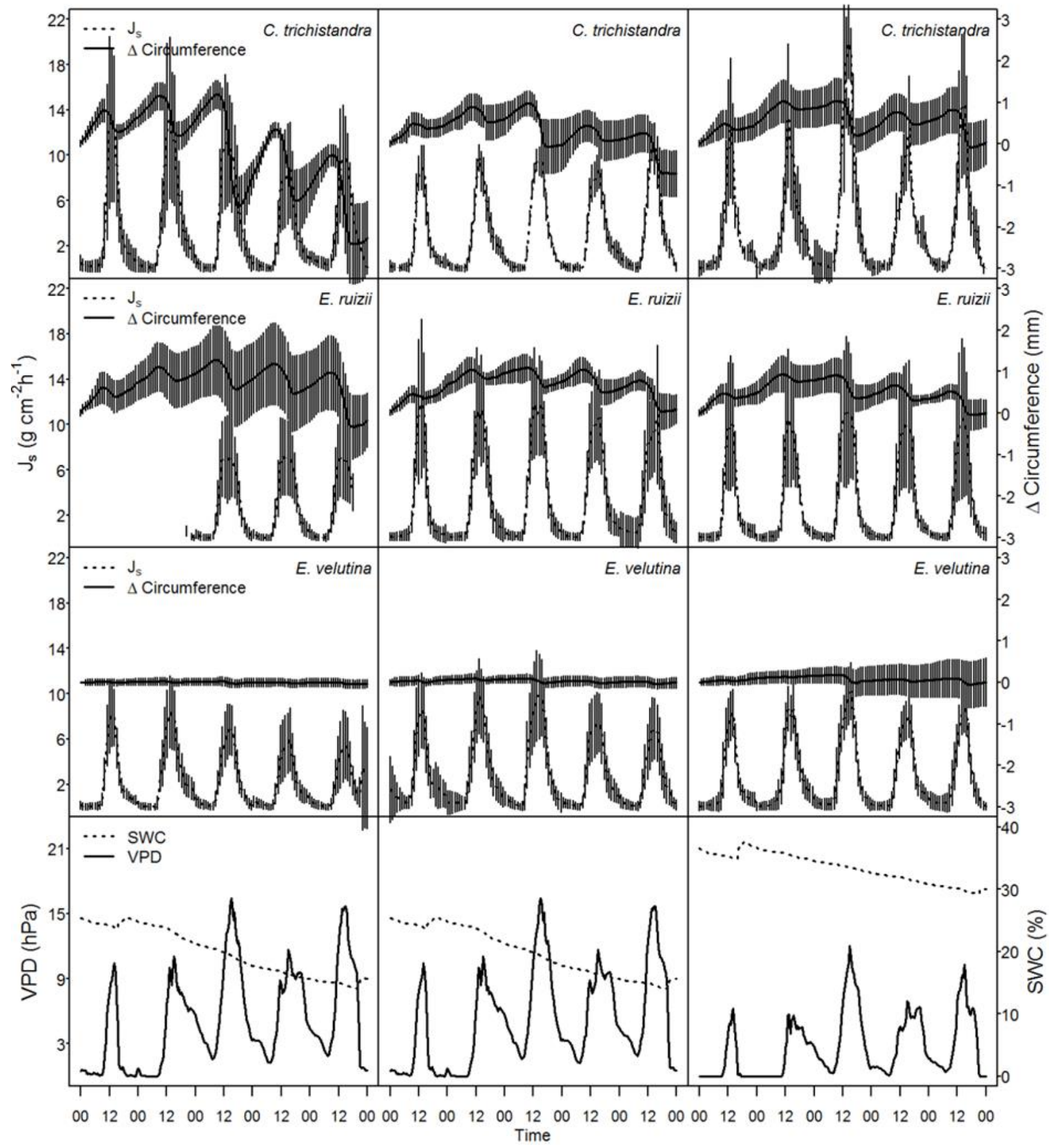

Figure 2.5 Middle of wet season (decreasing soil water level), course over five consecutive days (6.3.10.3. 2015) of diel change in stem circumference ( $\Delta$ Circumference measurements, solid line) and sap flux density $\left(\mathrm{J}_{\mathrm{s}}\right.$ measurements, dashed line) for $\mathrm{n}=4$ individuals per species and plot. Vapor pressure deficit (VPD, solid line) and volumetric soil water content (SWC, dashed line) is shown for all three elevations, little precipitation $(15 \mathrm{~mm})$ was recorded earlier, followed by two weeks of dry conditions. Missing sap flux data due to power shortages. Error bars represent standard deviation. 


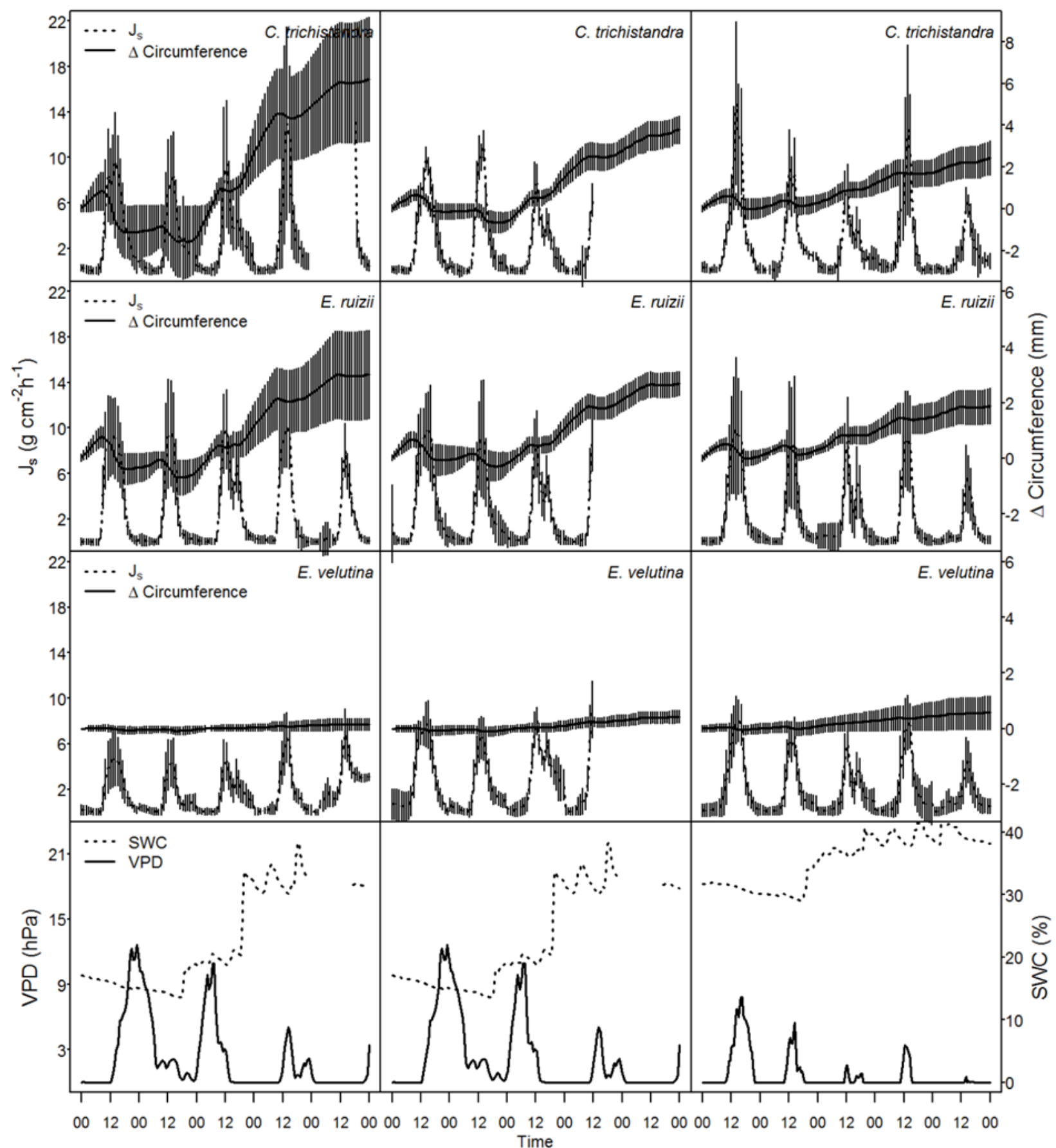

Figure 2.6 Middle of wet season (increasing soil water level), course over five consecutive days (16.3.20.3. 2015) of diel change in stem circumference ( $\Delta$ Circumference measurements, solid line) and sap flux density $\left(\mathrm{J}_{\mathrm{S}}\right.$ measurements, dashed line) for $\mathrm{n}=4$ individuals per species and plot. Vapor pressure deficit (VPD, solid line) and volumetric soil water content (SWC, dashed line) is shown for all three elevations, earlier no precipitation was recorded, it rained on 18th of March during the displayed period and continued raining. Missing sap flux data due to power shortages. Error bars represent standard deviation. 


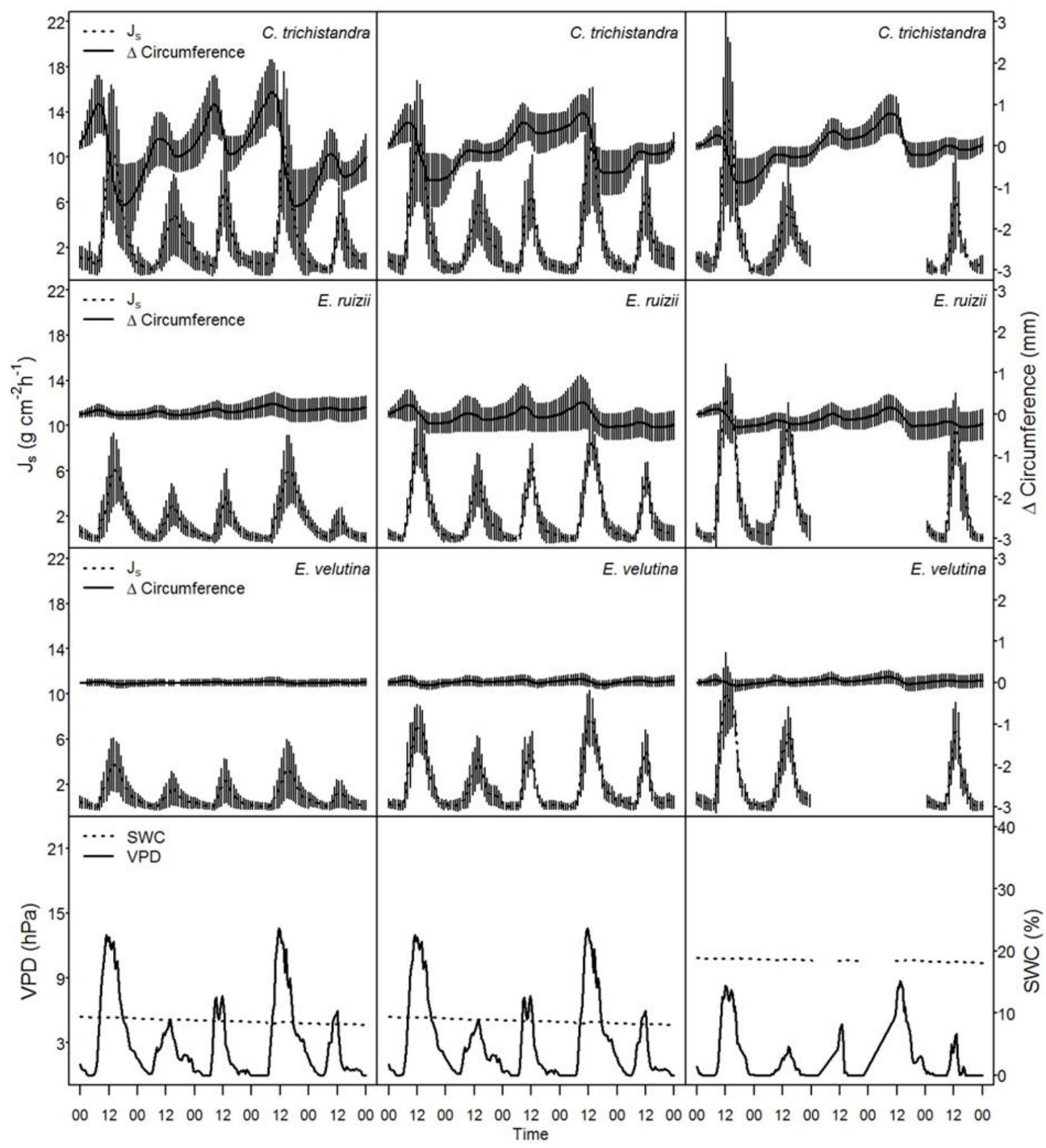

Figure 2.7 End of wet season, course over five consecutive days (20.5.-25.5.2015) of diel change in stem circumference ( $\Delta$ Circumference measurements, solid line) and sap flux density $\left(\mathrm{J}_{\mathrm{s}}\right.$ measurements, dashed line) for $\mathrm{n}=4$ individuals per species and plot. Vapor pressure deficit (VPD, solid line) and volumetric soil water content (SWC, dashed line) is shown for all three elevations, no precipitation was recorded earlier nor during the displayed period. Missing sap flux data due to power shortages. Error bars represent standard deviation. 


\subsubsection{Tree response to intermittent rain fall events in the dry season}

The first wet season and transition-phase from wet to dry (April-May 2014) was characterized by the occurrence of single precipitation events that brought low amounts of rainfall in April, but $70 \mathrm{~mm}$ precipitation in the first half of May, which is normally a rather dry month (Figure 2.1). This precipitation pattern induced early shedding of leaves and by the end of April all species were defoliated (Figure 2.3). The extended rainfall in the first half of May caused a short re-flushing of leaves in some individuals of $C$. trichistandra at 670 and $860 \mathrm{~m}$ asl. at the end of May, as indicated by increased sap flux rates (Figure 2.8). The same re-flushing was also observed for E. velutina, but no sap flux data were available due to power shortages during that time. E. ruizii did not respond to this rain event. A clear response to the precipitation in beginning of May is visible for C. trichistandra and E. ruizii as a pronounced stem circumference increase in the dendrometer data (Figure 2.2). By the time, $C$. trichistandra was re-flushing and increasing sap flux rates, the effect of the intermittent rain event on change in circumference disappeared (Figure 2.8).

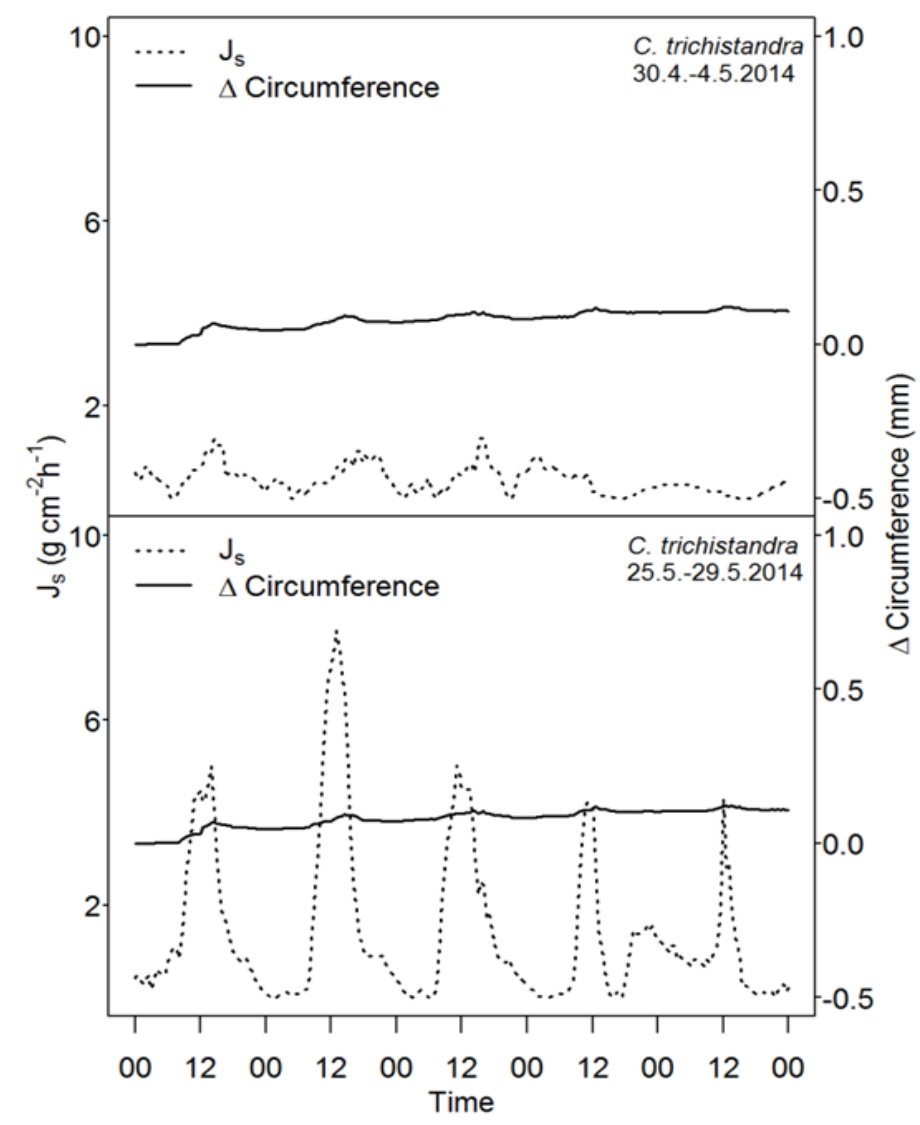

Figure 2.8 Course over five consecutive days of diel change in stem circumference (dendrometer measurements, solid line) and sap flux density (TDP measurements, dashed line) at 670m asl., after $5 \mathrm{~mm}$ of precipitation during April 2014 (upper panel, 30.4.-4.5.2014) C. trichistandra was completely defoliated and displayed no sap flux patterns, and after 70mm of precipitation during May 2014 (lower panel, 25.5.-29.5.2014) C. trichistandra was able to re-flush some leaves which led to increased sap flux rates. 


\subsubsection{Diurnal stem variations}

The diel stem shrinking and swelling processes can be divided into three distinct phases (stem increment, stem contraction, and stem recovery; Deslauriers et al., 2007) that are related to water loss during the day, stem refilling during the night, and cambial growth processes. Active tree growth is assumed when stem diameters exceed the previous maximum diameter of the stems (Deslauriers et al., 2007; Krepkowski et al., 2011; Spannl et al., 2016). Although air temperature is not a direct driver of plant water use, it affects environmental parameters like VPD, SWC, and transpiration rates strongly. Hence, stem diameter variations follow the diurnal course of environmental conditions that are related to air temperature (Figure 2.9). In case of $C$. trichistandra and E. ruizii, stem recovery started during the late afternoon and lasted until the early morning when it changed into growth. Stem recovery in E. velutina was prevalent until midnight; from then on constant growth was recorded lasting for approximately $7 \mathrm{~h}$ before the contraction phase restarted (Figure 2.9). These recovery and increment processes were not clearly distinguishable in C. trichistandra and E. ruizii. Those two species showed reversible stem shrinkage at hourly and seasonal scales, which can lead to negative increment rates. On the other hand, only little stem shrinkage was recorded for E. velutina during the dry season. Nevertheless, the growth habit of this species was characterized by strong seasonality (Figure 2.2). During the dry season a different effect was visible and E. velutina and E. ruizii started to recover during the day, while $C$. trichistandra showed similar reactions, but started contracting when a temperature threshold of $32{ }^{\circ} \mathrm{C}$ was exceeded (Figure 2.9). The absolute change in circumference was low during the dry season. 

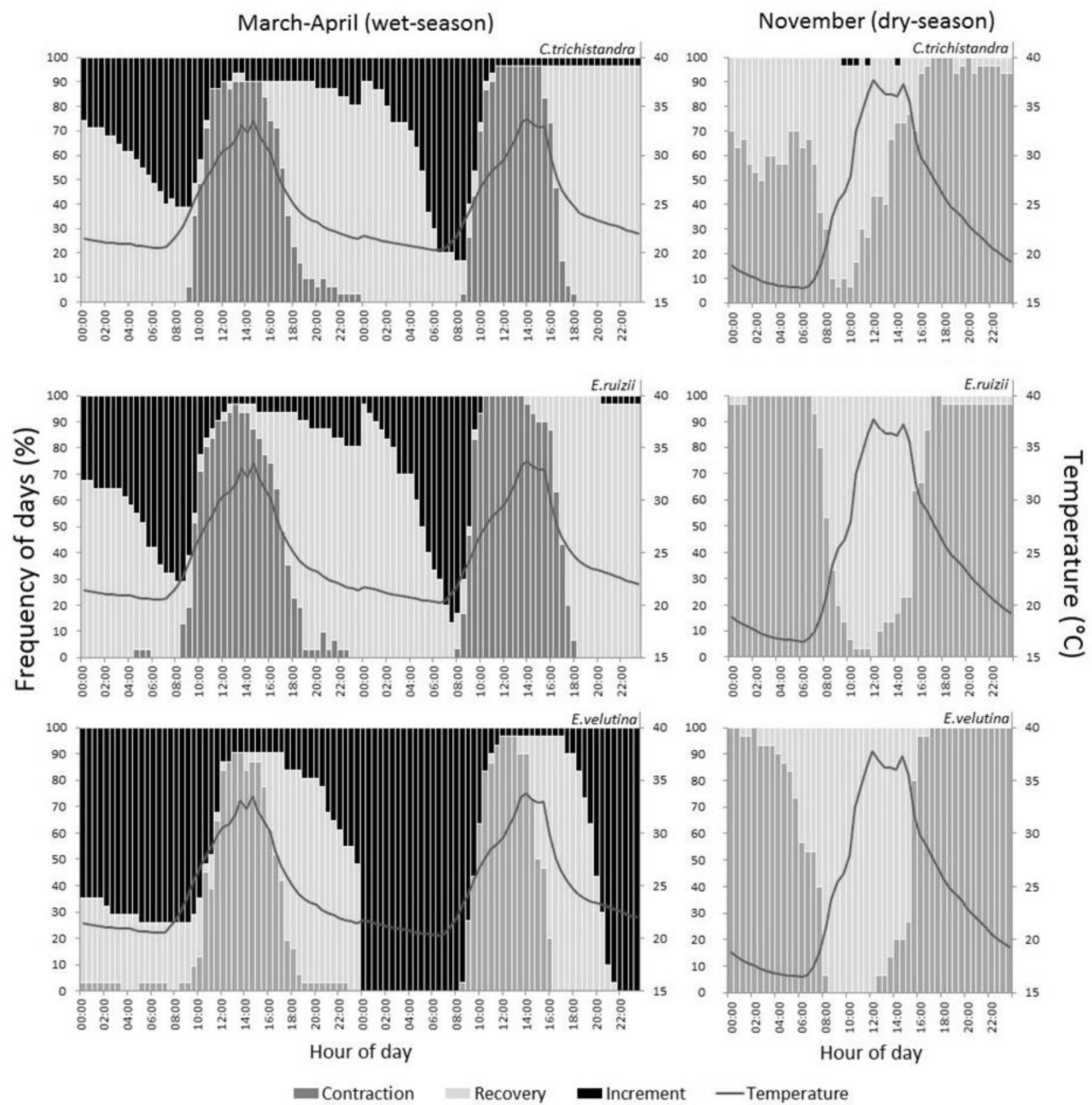

Figure 2.9 Changes in stem circumference during parts of the wet (March-April) and dry season (November), grey shading indicates the different phases of stem variation (increment, recovery, and contraction) for the indicated time for each day of the month, grey line displays diurnal changes of air temperature $\left({ }^{\circ} \mathrm{C}\right)$. Data are derived from band dendrometer recordings.

\subsubsection{Main drivers of stem variations, sap flux density and leaf phenology}

During the dry season all species shed their leaves, hence no foliage and no sap flux was observed (Table 2.3). Radial stem variations indicate moderate contraction for C. trichistandra and pronounced contraction for E. ruizii; E. velutina remained its circumference throughout the dry season. These observations are representative for the whole studied elevation gradient. In the early to middle wet season, VPD was the main driver for radial variations for $C$. trichistandra and E. velutina at the two 
lower elevations and for E. ruizii at the highest elevation. SWC influencing radial variation became important in the late wet season for all species, especially at the two lower study sites. Sap flux density showed a clear linkage to VPD throughout the early to middle wet season for all species in all elevations. During this time, the influence of SWC on sap flux density did not follow a clear pattern, but in the late wet season we observed a strong influence at the highest elevation for all three species. For the two lower plots VPD was identified as the main driver for sap flux density during the late wet season.

C. trichistandra reacted most sensitive to all driving variables. The main changes in circumference of C. trichistandra were influenced by VPD and SWC with respect to different climatic periods. The distinct phases, leaf flushing, leaf shedding and the ability to re-flush were clearly visible (Figure 2.2, Figure 2.4, Figure 2.8). The concordance of daily circumference changes of $C$. trichistandra and precipitation during the rainy season was investigated statistically. Highest correlations were found for daily circumference changes and precipitation amount of the preceding day $\left(\mathrm{R}^{2}\right.$ adj. $\left.=0.31 ; \mathrm{p}<0.01\right)$. The same effect was found for E. ruizii $\left(\mathrm{R}^{2} \mathrm{adj} .=0.27 \mathrm{p}<0.05\right)$, but not for E. velutina. 


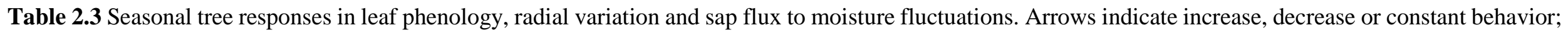
n.a.-data not available due to maintenance of sap flux installations.

\begin{tabular}{|c|c|c|c|c|c|c|c|c|c|c|c|c|}
\hline & \multicolumn{3}{|c|}{ Dry season } & \multicolumn{3}{|c|}{ Early wet season } & \multicolumn{3}{|c|}{ Middle wet season } & \multicolumn{3}{|c|}{ Late wet season } \\
\hline & $\begin{array}{l}\text { Canopy } \\
\text { foliage }\end{array}$ & $\begin{array}{l}\text { Sap } \\
\text { flux }\end{array}$ & $\begin{array}{l}\text { Radial } \\
\text { variation }\end{array}$ & $\begin{array}{l}\text { Canopy } \\
\text { foliage }\end{array}$ & $\begin{array}{l}\text { Sap } \\
\text { flux }\end{array}$ & $\begin{array}{l}\text { Radial } \\
\text { variation }\end{array}$ & $\begin{array}{l}\text { Canopy } \\
\text { foliage }\end{array}$ & $\begin{array}{l}\text { Sap } \\
\text { flux }\end{array}$ & $\begin{array}{l}\text { Radial } \\
\text { variation }\end{array}$ & $\begin{array}{l}\text { Canopy } \\
\text { foliage }\end{array}$ & $\begin{array}{l}\text { Sap } \\
\text { flux }\end{array}$ & $\begin{array}{l}\text { Radial } \\
\text { variation }\end{array}$ \\
\hline \multicolumn{13}{|c|}{ Lower slope $(670 \mathrm{~m})$} \\
\hline C.trichistandra & none & none & $\downarrow$ & $\uparrow$ & $\uparrow$ & $\uparrow$ & $\rightarrow$ & $\rightarrow$ & $\uparrow$ & $\downarrow$ & $\downarrow$ & $\uparrow$ \\
\hline E.ruizii & none & none & $\downarrow$ & $\uparrow$ & n.a. & $\uparrow$ & $\rightarrow$ & $\rightarrow$ & $\uparrow$ & $\downarrow$ & $\downarrow$ & $\rightarrow$ \\
\hline E.velutina & none & none & $\rightarrow$ & $\uparrow$ & n.a. & $\rightarrow$ & $\rightarrow$ & $\rightarrow$ & $\uparrow$ & $\downarrow$ & $\downarrow$ & $\rightarrow$ \\
\hline \multicolumn{13}{|c|}{ Middle slope $(860 \mathrm{~m})$} \\
\hline C.trichistandra & none & none & $\downarrow$ & $\uparrow$ & $\uparrow$ & $\uparrow$ & $\rightarrow$ & $\rightarrow$ & $\uparrow$ & $\downarrow$ & $\downarrow$ & $\uparrow$ \\
\hline E.ruizii & none & none & $\downarrow$ & $\uparrow$ & $\uparrow$ & $\uparrow$ & $\rightarrow$ & $\rightarrow$ & $\uparrow$ & $\downarrow$ & $\downarrow$ & $\uparrow$ \\
\hline E.velutina & none & none & $\rightarrow$ & $\uparrow$ & $\uparrow$ & $\rightarrow$ & $\rightarrow$ & $\rightarrow$ & $\uparrow$ & $\downarrow$ & $\downarrow$ & $\rightarrow$ \\
\hline \multicolumn{13}{|c|}{ Upper slope (1100 m) } \\
\hline C.trichistandra & none & none & $\downarrow$ & $\uparrow$ & $\uparrow$ & $\uparrow$ & $\rightarrow$ & $\rightarrow$ & $\uparrow$ & $\downarrow$ & $\rightarrow$ & $\uparrow$ \\
\hline E.ruizii & none & none & $\downarrow$ & $\uparrow$ & $\uparrow$ & $\uparrow$ & $\rightarrow$ & $\rightarrow$ & $\uparrow$ & $\downarrow$ & $\rightarrow$ & $\uparrow$ \\
\hline E.velutina & none & none & $\rightarrow$ & $\uparrow$ & $\uparrow$ & $\rightarrow$ & $\rightarrow$ & $\rightarrow$ & $\uparrow$ & $\downarrow$ & $\downarrow$ & $\rightarrow$ \\
\hline
\end{tabular}




\subsection{Discussion}

The studied trees responded sensitive to fluctuating moisture regimes with leaf phenology, sap flux and stem diameter variations. We found differences among species and along an altitudinal gradient and want to clarify which species or physiological trait is most suitable as indicator. To evaluate and interpret the differences we applied linear regressions, however it was not possible to address spatial autocorrelation due to our plot design. So far only a limited number of sap flux studies along environmental gradients exist, that explicitly address the problem of spatial autocorrelation (Adelman et al., 2008; Loranty et al., 2008). Our approach followed other ecological studies facing similar problems (e.g. Nilsen et al., 1990; Malhi et al., 2004; Kubota et al., 2005; Kume et al., 2006; Mendivelso et al., 2016). Regarding future studies this issue should be addressed more carefully in the study design.

\subsubsection{Response of diurnal stem diameter variations to fluctuating moisture regimes and climate}

Main drivers for stem water status in tropical dry forests are precipitation, SWC and temperature (Singh and Kushwaha, 2016). Stem water status depends on the balance of absorption of water by the roots and water loss through leaf transpiration (Borchert, 1999). Contraction and swelling phases recorded during the rainy season therefore can be related to tree water relations, which in turn are connected to environmental variables (Steppe et al., 2015). The first water transpired during the early day is the water stored in the branches near the crown (Goldstein et al., 1998). In our study, on a bright day, these reserves were rapidly depleted through increasing transpiration rates, driven by increasing VPD, leading to further depletion of the stem water storage over midday and to stem contraction (Figure 2.9). This relation of stem contraction and air temperature indicates that transpiration and water loss through the crown are responsible for stem shrinkage for all our studied species during the rainy season. During the dry season when water is the principal limiting factor for tree physiological activity, the main part of stored stem water is located in the sapwood (Singh and Kushwaha, 2016). The quantity of stored water negatively correlates with wood density and increases with the amount of living parenchyma cells. In addition, the link between hydraulic properties (i.e. stem water storage capacity, xylem water transport, regulation of leaf water status and avoidance of turgor loss) and wood density should be taken into account, since tree physiological efficiency is dependent on these factors (Singh and Kushwaha, 2016). Our findings for the dry season (Figure 2.9) indicated stem swelling throughout the day in the absence of sap flux and foliation, this could refer to thermal expansion of stored water in the wood and is comparable to results obtained in Bolivia on Cedrela fissilis and Centrolobium microchaete (Mendivelso et al., 2016). As a result, the observed seasonality and different phenological responses may be related to the differences in wood density and anatomy (hydraulic properties of the stem) as well as the seasonal fluctuations in stem water status caused by SWC and VPD. 


\subsubsection{Differences among species along the gradient}

Stem diameter variations of $C$. trichistandra responded to SWC by swelling and shrinking during the whole wet season. This species reacted very fast to rain-events with water uptake and related stem rehydration and growth. The increase of stem circumference was only interrupted when SWC decreased. At the end of the wet season, changes in circumference declined within two weeks with little or no rain. During the following dry season, a slight decrease of circumference was recorded in 2014, whereas in 2015 circumference remained stable. Trees from tropical dry forests normally show reduced or even absent cambial activity after the start of the dry season, regardless of their leaf phenology (Worbes et al., 2013). Sap flux density of $C$. trichistandra correlated with VPD if SWC levels were high. This was especially due at $1100 \mathrm{~m}$ asl., where SWC was not limiting. As a stem succulent, $C$. trichistandra has a low wood density and a high proportion of parenchyma cells, which can take up high amounts of water in short time. This leads to a gain of wood stability due to hydraulic support (Romberger et al., 1993). Our findings indicate a limited use of stem water despite of early flushing, which was also described for Adansonia spp. trees of the same family (Chapotin et al., 2006).

E. ruizii was sensitive to soil moisture variations during the whole growing season, showing pronounced shrinking and swelling of water conducting tissue of the bark, which contributes to the stem's total capacitance (Díaz-Espejo et al., 2013; Rosell and Olson, 2014). This species is a root succulent with water storage organs below ground. Hence, E. ruizii did not respond to daily changes in VPD, leading to less pronounced diel stem diameter amplitudes compared to C. trichistandra.

E. velutina showed most pronounced stem diameter variations at the end of the wet season. In contrast to the other two species, E. velutina did not exhibit a pronounced diurnal shrinking and swelling, which indicates that it has only sparse internal water reserves even though it has very low wood density. Therefore E. velutina might be able to cope with short drought events by immediate leaf shedding and when conditions have recovered, with re-flushing of leaves (Díaz and Granadillo, 2003). The ability of fast leaf shedding is considered an adaptation to avoid vessel cavitation due to water stress, which is common in pioneer species with low wood density (Méndez-Alonzo et al., 2013). Sap flux showed its strongest correlation to VPD at the highest site and during the early to middle wet season, but correlation vanished during periods of decreasing SWC at the end of the wet season. We observed a uniform and synchronous bud break of $C$. trichistandra approximately one month before the first rains in the late dry season. This phenomenon was observed at different elevations in the study area, as well as surrounding parts, and may indicate a changing length of the photoperiod as controlling factor for bud break in $C$. trichistandra. Borchert et al. (2002) found this especially to be the case for trees in equatorial forests. The other two species showed a direct response to the onset of the first rains in the early wet season. Due to the undulating terrain of the study area and a resulting high spatial variation in micro-climatic conditions, these first rain-events occurred unevenly distributed and therefore an asynchronous bud break can be expected. Due to the high inter-annual variations in the amount and distribution of rains 
and thus the length of the growing season we could clearly observe an effect on leaf phenology, like early shedding of leafs or re-flushing events. The response to moisture fluctuations revealed intraspecies variations in phenology, guided by changes in SWC. We found a prolonged foliation at the highest elevation during the late wet season, when trees at lower elevations already started leaf shedding and decreased sap flux rates. The flexibility in leaf fall timing broadens the ecological range of different species within the tropical dry forest ecosystem.

Tropical dry forests are often composed of trees belonging to different functional types, in which bud break, flushing and shedding of leaves occur at varying times during and after the dry season (Borchert, 1996; Borchert et al., 2002). Vegetative bud break can be triggered for example by the length of the photoperiod or first rains at the beginning of the wet season (Rivera et al., 2002). The elevation gradient is manifested in an increasing length of the leaved periods of all species, which is most likely related to differences in moisture regime. The factor responsible for the initiation of certain phenological events may be determined by careful observation of tree behavior over consecutive study years.

\subsubsection{Tree indicators of climate change in a dry forest}

Clear differences among species, topographic positions, radial growth and tree water use patterns were revealed. Our results indicate a strong sensitivity of $C$. trichistandra to changes in moisture regime regarding radial stem variations and leaf phenology, especially at the lowest elevation. E. ruizii is equally sensitive, but only in its response in radial stem variations. E. velutina shows indicator potential due to its phenology, i.e. the ability to re-flush. These responses make the species suitable as indicator species at different scales. Sap flux density measurements were also indicative, but are very costly in terms of equipment and maintenance. Leaf phenology can be easily observed from the ground or by remote sensing. Radial stem variation data is more expensive to collect but shows a high level of detail and needs low maintenance.

\subsubsection{Conclusion}

During the rainy season, stem circumference of $C$. trichistandra and E. ruizii responded very sensitive to even small amounts of precipitation or changes in SWC. In contrast, E. velutina did not respond to short-term variations in water availability, but reacted on a seasonal scale. During the dry season minor stem contraction occurred in C. trichistandra, and major contraction in E. ruizii, whereas E. velutina was able to retain its stem circumference. The immediate visible change in circumference allowed detailed comparison between different phases considering SWC. Sap flow showed a more complex seasonal course influenced by a couple of determinants, and is therefore well suited for physiological research, but not as a straightforward indicator. C. trichistandra showed a clear response to subtle changes in moisture availability, which was reflected in its leaf phenology and radial stem variations. $E$. 
ruizii shows an equally sensitive response regarding radial stem variation, but would not be of use considering leaf phenological observations. E. velutina would only be viable for a phenological approach, but a clear visible reaction in radial stem circumference could indicate extreme climatic events. This could be useful in the context of the large distributional area of this species. C. trichistandra can be thus regarded as the most valuable indicator tree for changes in seasonality and rainfall regimes, and may contribute as an indicator towards monitoring ecosystem functions of the South Ecuadorian dry forest ecosystem.

The link between physiological characteristics (i.e. stem succulence of $C$. trichistandra and water storage in bark for E. ruizii) and indicator species based on radial stem variation needs further investigation.

\section{Acknowledgements}

The financial support granted by the German Science Foundation (DFG) through PAK823-825 'Platform for Biodiversity and Ecosystem Monitoring and Research in South Ecuador' (BR1895/23-1, GR 4293/2-1, HO 2119/7-1) is gratefully acknowledged. We thank the Ecuadorian Ministry of the Environment (MAE) for the research permission and Nature and Culture International (NCI) for logistic support. We also express our gratitude to Hannah Luise Bettac and Maria Cabrera who took the hemispherical photographs. 


\subsection{References Chapter 2}

Adelman, J.A., Ewers, B.E., Mackay, D.S., 2008. Using temporal patterns in vapor pressure deficit to explain spatial autocorrelation dynamics in tree transpiration. Tree Physiol. 28, 647-658.

Borchert, R., Rivera, G., Hagnauer, W., 2002. Modification of vegetative phenology in a tropical semi-deciduous forest by abnormal drought and rain. Biotropica 34, 27-39.

Borchert, R., 1994. Soil and stem water storage determine phenology and distributionof tropical dry forest trees. Ecology 75, 1437-1449.

Borchert, R., 1999. Climatic periodicity, phenology, and cambium activity in tropicaldry forest trees. IAWA J. 20, 239-247.

Brodribb, T., Holbrook, N., 2003. Changes in leaf hydraulic conductance during leaf shedding in seasonally dry tropical forest. New Phytol. 158, 295-303.

Brodribb, T.J., Holbrook, N.M., Edwards, E.J., Gutiérrez, M.V., 2003. Relations between stomatal closure, leaf turgor and xylem vulnerability in eight tropical dry forest trees. Plant Cell Environ. 26, 443-450.

Bucci, S.J., Goldstein, G., Meinzer, F.C., Franco, A.C., Campanello, P., Scholz, F.C., 2005. Mechanisms contributing to seasonal homeostasis of minimum leaf water potential and predawn disequilibrium between soil and plant water potential in Neotropical savanna trees. Trees 19, 296-304.

Bullock, S.H., Mooney, H.A., Medina, E., 1995. Seasonally dry tropical forests. 1st ed. Cambridge.

Buzzard, V., Hulshof, C.M., Birt, T., Violle, C., Enquist, B.J., 2015. Re-growing a tropical forest: functional plant trait composition and community assembly during succession. Funct. Ecol. 30, 1006-1013.

Chapotin, S.M., Razanameharizaka, J.H., Holbrook, N.M., 2006. Water relations of baobab trees (Adansonia spp. L.) during the rainy season: does stem water buffer daily water deficits?. Plant Cell Environ. 29, $1021-1032$.

Curtis, J.T., McIntosh, R.P., 1951. An upland forest continuum in the prairie-forest border region of Wisconsin. Ecology 32, 476-496.

Díaz, M., Granadillo, E., 2003. The significance of episodic rains for reproductive phenology and productivity of trees in semiarid regions of northwestern Venezuela. Trees 19, 336-348.

Díaz-Espejo, A., Nicolás, E., Nortes, P., Rodriguez-Dominguez, C.M., Cuevas, M.V., Perez-Martin, A., TorresRuiz, J., 2013. Xylem functioning and water relations of the elastic living tissue of the bark: new insights about their coordination. Acta Hortic. 991, 163-169. 
Deslauriers, A., Rossi, S., Anfodillo, T., 2007. Dendrometer and intraannual tree growth: what kind of information can be inferred?. Dendrochronologia 25, 113-124.

Dupuy, J.M., Hernández Stefanoni, J.L., Hernández Juárez, R.A., Tetetla-Rangel, E., López-Martínez, J.O., Leyequién-Abarca, E., TunDzul, F., May-Pat, M., 2012. Patterns and correlates of tropical dry forest structure and composition in a highly replicated chronosequence in Yucatan, Mexico. Biotropica 44, $151-162$.

Espinosa, C.I., Cabrera, O., Luzurlaga, A.L., Escudero, A., 2011. What factors affect diversity and species composition of endangered Tumbesian dry forests in Southern Ecuador?. Biotropica 43 (1), 15-22.

Estrada-Medina, H., Santiago, L.S., Graham, R.C., Allan, M.F., Jimenez-Osornio, J.J., 2013. Source water, phenology and growth of two tropical dry forest tree species growing on shallow karst soils. Trees 27, $1297-1307$.

Fournier, L.A., 1974. Un método cuantitativo para la medición decaracterísticas fenológicas en árboles. Turrialba 24, 422-423.

Fu, P.L., Jiang, Y.J., Wang, A.Y., Brodribb, T.J., Zhang, J.L., Zhu, S.D., Cao, K.F., 2012. Stem hydraulic traits and leaf water-stress tolerance are co-ordinated with the leaf phenology of angiosperm trees in an Asian tropical dry karst forest. Ann. Bot. 110, 189-199.

Gebrekirstos, A., Teketay, D., Fetene, M., Mitlöhner, R., 2006. Adaptation of five co-occurring tree and shrub species to water stress and its implication in restoration of degraded lands. For. Ecol. Manage. 229, 259267.

Goldstein, G., Andrade, J.L., Meinzer, F.C., Holbrook, N.M., Cavelier, J., Jackson, P., Celis, A., 1998. Stem water storage and diurnal patterns of water use in tropical forest canopy trees. Plant Cell Environ. 21, $397-406$.

Granier, A., 1987. Evaluation of transpiration in a Douglas-fir stand by means of sap flow measurements. Tree Physiol. 3, 309-320.

Knoke, T., Bendix, J., Pohle, P., Hamer, U., Hildebrandt, P., Roos, K., Gerique, A., Sandoval, M.L., Breuer, L., Tischer, A., Silva, B., Calvas, B., Aguirre, N., Castro, L.M., Windhorst, D., Weber, M., Stimm, B., Günter, S., Palomeque, X., Mora, J., Mosandl, R., Beck, E., 2014. Afforestation or intense pasturing improve the ecological and economic value of abandoned tropical farmlands. Nat. Commun. 5, 5612.

Krepkowski, J., Bräuning, A., Gebrekirstos, A., Strobl, S., 2011. Seasonal growth dynamics and climatic control of different tree life forms in Munessa Forest (Ethiopia). Trees 25, 59-70. 
Kubota, M., Tenhunen, J., Zimmermann, R., Schmidt, M., Adiku, S., Kakubari, Y., 2005. Influences of environmental factors on the radial profile of sap flux density in Fagus crenata growing at different elevations in the Naeba Mountains, Japan. Tree Physiol. 25, 545-556.

Kume, T., Takizawa, H., Yoshifuji, N., Tanaka, K., Tantasirin, C., Tanaka, N., Suzuki, M., 2006. Impact of soil drought on sap flow and water status of evergreen trees in a tropical monsoon forest in northern Thailand. For. Ecol. Manage. 238 (2007), 220-230.

Loranty, M.M., Mackay, D.S., Ewers, B.E., Adelman, J.D., Kruger, E.L., 2008. Environmental drivers of spatial variation in whole-tree transpiration in an aspen-dominated upland-to-wetland forest gradient. Water Resour. Res. 44, W02441.

Méndez-Alonzo, R., Pineda-García, F., Paz, H., Rosell, J.A., Olson, M.E., 2013. Leaf phenology is associated with soil water availability and xylem traits in a tropical dry forest. Tree 27, 745-754.

Maestre, F., Quero, J., Gotelli, N., Escudero, A., Ochoa, V., Delgado-Baquerizo, M., García Gómez, M., Bowker, M., Soliveres, S., Escolar, C., García-Palacios, P., Berdugo, M., Valencia, E., Gozalo, B., Gallardo, A., Aguilera, L., Arredondo, T., Blones, J., Boeken, B., Bran, D., Conceição, A., Cabrera, O., Chaieb, M., Derak, M., Eldridge, D., Espinosa, C., Florentino, A., Gaitán, J., Gatica, G., Ghiloufi, W., Gómez-González, S., Gutiérrez, R., Hernández, R., Huang, X., Huber-Sannwald, E., Jankju, M., Miriti, M., Monerris, J., Mau, R., Morici, E., Naseri, K., Ospina, A., Polo, V., Prina, A., Pucheta, E., RamírezCollantes, D., Romão, R., Tighe, M., Torres-Díaz, C., Val, J., Veiga, J., Wang, D., Zaady, E., 2012. Plant species richness and ecosystem multifunctionality in global drylands. Science 335, 214-218.

Malhi, Y., Baker, T.R., Phillips, O.L., Almeida, S., Alvarez, E., Arroyo, L., Chave, J., Czimczik, C.I., Di Fiore, A., Higuchi, N., Killeen, T.J., Laurance, S.G., Laurance, W.F., Lewis, S.L., Mercado, L.M., Monteagudo, A., Neill, D.A., Nunez, P., Patino, S., Pitman, N.C.A., Quesada, C.A., Salomao, R., Silva, J.N.M., Torres, A., Vasquez, R., Terborgh, J., Vinceti, B., Lloyd, J., 2004. The above-ground coarse wood productivity of 104 Neotropical forest plots. Global Change Biol. 10, 563-591.

Mayle, F.E., 2004. Assessment of the Neotropical dry forest refugia hypothesis in the light of palaeoecological data and vegetation model simulations. J. Quat. Sci. 19, 713-720.

Mendivelso, H.A., Camarero, J.J., Gutiérrez, E., 2016. Climatic influences on leaf phenology, xylogenesis and radial stem changes at hourly to monthly scales in two tropical dry forests. Agric. For. Meteorol. 216, $20-36$.

Nilsen, E.T., Sharifi, M.R., Rundel, P.W., Forseth, I.N., Ehleringer, J.R., 1990. Water relations of stem succulent trees in north-central Baja California. Oecologia 82, 299-303. 
Pineda-Garcia, F., Paz, H., Meinzer, F.C., 2013. Drought resistance in early and late secondary successional species from a tropical dry forest: the interplay between xylem resistance to embolism sapwood water storage and leaf shedding. Plant Cell Environ. 36, 405-418.

Pucha Cofrep, D., Peters, T., Bräuning, A., 2015. Wet season precipitation during the past 120 years reconstructed from tree rings of a tropical dry forest in Southern Ecuador. Global Planet. Change 133, $65-78$.

R Development Core Team, 2015. R: A Language and Environment for Statistical Computing. R Foundation for Statistical Computing, Vienna, Austria, ISBN 3-900051-07-0.

Rivera, G., Elliott, H., Caldas, L.S., Nicolossi, G., Coradin, V.T., Borchert, R., 2002. Increasing day-length induces spring flushing of tropical dry forest trees in the absence of rain. Trees 16, 445-456.

Romberger, A., Hejnowicz, Z., Hill, J., 1993. Plant Structure: Function and Development. Springer, Berlin, Germany.

Rosell, J., Olson, M., 2014. The evolution of bark mechanics and storage across habitats in a clade of tropical trees. Am. J. Bot. 101 (5), 764-777.

Sayer, E.J., Newbery, D.M., 2003. The role of tree size in the leafing phenology of seasonally dry tropical forest in Belize, Central America. J. Trop. Ecol. 19, 539-548.

Singh, K.P., Kushwaha, C.P., 2016. Deciduousness in tropical trees and its potential as indicator of climate change: a review. Ecol. Indic. 69, 699-706.

Souza, E.M.S., Pereira, G.S., Silva-Mann, R., Álvares-Carvalho, S.V., Ferreira, R.A., 2016. A comparative framework of the Erythrina velutina tree species in reforested land and native populations. Genet. Mol. Res. 15 (2).

Spannl, S., Volland, F., Pucha, D., Peters, T., Bräuning, A., 2016. Climate variability, tree increment patterns and ENSO-related carbon sequestration reduction of the tropical dry forest species Loxopterygium huasango of Southern Ecuador. Trees 30, 1245-1258.

Steppe, K., Sterck, F., Deslauriers, A., 2015. Diel growth dynamics in tree stems: linking anatomy and ecophysiology. Trends Plant Sci. http://dx.doi.org/10.1016/j.tplants.2015.03.015.

Stratton, L., Goldstein, G., Meinzer, F.C., 2000. Stem water storage capacity and efficiency of water transport: their functional significance in Hawaiian dry forest. Plant Cell Environ. 23, 99-106.

Volland-Voigt, F., Bräuning, A., Ganzhi, O., 2009. High-resolution dendrometer measurements in a tropical lower montane forest and a dry forest in South Ecuador. Tree Rings Archaeol. Climatol. Ecol. 7, 85-88. 
Volland-Voigt, F., Bräuing, A., Ganzhi, O., Peters, T., Maza, H., 2011. Radial stem variations of Tabebuia chrysantha (Bignoniaceae) in different tropical forest ecosystems of southern Ecuador. Trees 25, 39-48.

Wagner, F., Rossi, V., Aubry-Kientz, M., Bonal, D., Dalitz, H., 2014. Pan-tropical analysis of climate effects on seasonal tree growth. PLoS One 9 (3), e92337.

Wagner, F.H., et al., 2016. Climate seasonality limits carbon assimilation and storage in tropical forests. Biogeosciences 13, 2537-2562.

Worbes, M., Blanchart, S., Fichtler, E., 2013. Relations between water balance, wood traits and phenological behavior of tree species from a tropical dry forest in Costa Rica - a multifactorial study. Tree Physiol. $33,527-536$.

Zanne, A.E., Lopez-Gonzalez, G., Coomes, D.A., Ilic, J., Jansen, S., Lewis, S.L., Miller, R.B., Swenson, N.G., Wiemann, M.C., Chave, J., 2009. Data from: towards a worldwide wood economics spectrum. Dryad Digit. Reposit. http://dx.doi.org/10.5061/dryad.234 


\section{Chapter 3}

\section{Tree Water Use Patterns as Influenced by Phenology in a Dry Forest of Southern Ecuador}

Philipp Butz ${ }^{1 * \dagger}$, Dirk Hölscher ${ }^{1}$, Eduardo Cueva $^{2}$, Sophie Graefe ${ }^{1}$

${ }^{1}$ Tropical Silviculture and Forest Ecology, Georg-August-University Göttingen, Germany

${ }^{2}$ Nature and Culture International, Loja, Ecuador

${ }^{\dagger}$ Correspondence to: Philipp Butz, Tropical Silviculture and Forest Ecology, Georg-August-University Göttingen, Germany, Email address: butzens@gmail.com

Published in: Frontiers in Plant Science, July 2018| Volume 9| Article 945

doi: 10.3389/fpls.2018.00945

Chapter version: as published in Frontiers in Plant Science 


\section{Abstract Chapter 3}

Tropical dry forests are composed of tree species with different drought coping strategies and encompass heterogeneous site conditions. Actual water use will be controlled by soil moisture availability. In a premontane dry forest of southern Ecuador, tree water use patterns of four tree species of different phenologies were studied along an elevational gradient, in which soil moisture availability increases with altitude. Main interest was the influence of variation in soil moisture, vapor pressure deficit, species (representing phenology), elevation, and tree diameter on water use. Special emphasis was put on the stem succulent, deciduous Ceiba trichistandra, as high water use rates and drought coping involving stem succulence was to be expected. Tree water use rates increased linearly with diameter across species at high soil water content. However, when soil moisture declined, sap flux densities of the species responded differently. The stem succulent, deciduous Ceiba and other deciduous tree species reduced sap flux sensitively, whereas sap flux densities of the evergreen (broad leaved) Capparis scabrida were increasing. This was also reflected in diurnal hysteresis loops of sap flux vs. vapor pressure deficit (VPD) of the air. Under dry soil conditions, Ceiba and other deciduous tree species had much smaller areas in the hysteresis loop, whereas the area of Capparis was largely enhanced compared to wet conditions. The evergreen Capparis potentially had access to deeper soil water resources as water use patterns suggest that top soil drought was tolerated. The deciduous species followed a drought avoidance strategy by being leafless in the dry season. The stem succulent deciduous Ceiba flushed leaves at the end of the dry season before the rainy season began and also re-flushed early in the dry season after a rain event; however, water use rates at this occasion remained low. Ceiba was also ready for fast and strong response in water use when conditions were most favorable during the wet season. The study thus indicates a strong influence of species' drought coping strategy on water use patterns in tropical dry forests.

Keywords: drought, leaf phenology, sap flux, soil moisture, stem succulence 


\subsection{Introduction}

Drylands cover approximately $42 \%$ of the global land surface (Sorensen, 2009). They receive low annual rainfall volumes with a pronounced seasonal distribution, and according to climate change scenarios they may further expand (Huang et al., 2016). The forest area in dryland biomes has recently been found to be significantly larger than previously estimated (Bastin et al., 2017). 48\% Of all dryland forest is located in the tropics and $63 \%$ of the tropical dry forest area has a tree canopy cover of $40 \%$ and are thus according to FAO (2001) definition considered as closed forest (Bastin et al., 2017). Due to their vast occurrence and resulting high diversity the variety of mechanisms through which species in tropical dry forests avoid or tolerate drought are partly unknown (Delzon, 2015).

In tropical dry forests and other regions with seasonal water limitation, tree species with different drought coping strategies often co-occur. Mainly based on leaf phenology they are classified as (i) deciduous species that shed their leaves at the beginning of the dry season and re-flush at the beginning of the wet season; (ii) deciduous, stem succulent species, which mainly differ from the former category by their big trunks and early leaf flush at the end of the dry season; (iii) brevi-deciduous tree species with a short leafless period of a couple of weeks during the dry season, during which all leaves are shed and replaced by new ones; and (iv) evergreen species (Borchert, 1996). Deciduousness is interpreted as drought avoidance, whereas evergreen species are considered drought tolerant (Borchert, 1994b, 1998; Allen et al., 2017). Likewise, the approach of Schwinning and Ehleringer (2001) for plants in water limited biomes distinguishes drought avoidance and drought tolerance based on the phenology of evergreen, drought deciduous, and stem succulent deciduous species. In general, stomata of droughtdeciduous species are more sensitive to changes in soil water availability than those of evergreen species, with deciduous species exhibiting greater declines in stomatal conductance than co-existing evergreen species during dry periods (Myers et al., 1997; Eamus and Prior, 2001). For the latter, water use during the dry season is explained by deep reaching roots with access to deep water reservoirs (Elliott et al., 2006).

Among trees of a given forest and irrespective of species identity, tree water use rates and tree diameter underlie a typical scaling relationship (Meinzer et al., 2004, 2005; McJannet et al., 2007), at least under favorable conditions. Tropical dry forest trees may show similar relationships but conditions will often be non-favorable, and drought response in water use among such species remains little studied. Of particular interest are stem succulent species which occur in several taxa, often reaching extraordinary diameter classes, exceeding by far co-existing species and suggesting high water use capacities. In general, stem water dynamics are known to play an important role as an intermediate source of water for transpiration (Goldstein et al., 1998; Meinzer et al., 2001); in tropical as well as temperate regions, their contribution to total transpiration (in soft- and hardwood species) ranges from 10 to $50 \%$ (Carrasco et al., 2014). In dry forests, stem water storage so far has been linked with water demands for 
reproduction and leaf flushing during the dry season (Reich and Borchert, 1984; Borchert, 1994a). Studies in the stem succulent, deciduous baobab trees (Adansonia spp.) showed that leaf flush at the end of the dry season almost entirely depended on stem water storage; which was also important for conduit safety and turgor maintenance during the wet season, but apparently was not used for maximizing stomatal opening (Chapotin et al., 2006a,b). Astonishingly, despite tree sizes and very large diameters, the water use rates were not extraordinarily high. This indicates a rather limited role of stored stem water in baobabs for daily transpiration in the wet season; instead it enables leaf flush in the late dry season under arid conditions (Chapotin et al., 2006a,b). If this phenomenon is uniquely found in the stem succulent Baobabs of Madagascar, or as well in other species in similar biomes, remains unknown.

The present study was conducted in southern Ecuador at the western fringes of the Andes in a relatively well-preserved remnant of the Tumbesian dry forest. In this premontane tropical dry forest four tree species were studied along an elevational gradient, in which soil moisture availability increases with altitude due to higher influence of wet air coming from the Pacific. The overall objective was to analyze the importance of soil moisture changes for tree water use with respect to drought coping strategies among four phenologically different tree species (deciduous stem succulent, deciduous, brevideciduous, and evergreen). Next to soil water content and species, we also examined the influence of vapor pressure deficit, elevation, and tree diameter to assess particular influences of these factors in this tropical dry forest area. Of special interest was the scaling relationship of water use-diameter and phenology of the stem succulent Ceiba trichistandra due to its outstanding diameter and obvious water storing capacities.

\subsection{Materials and methods}

\subsubsection{Study area}

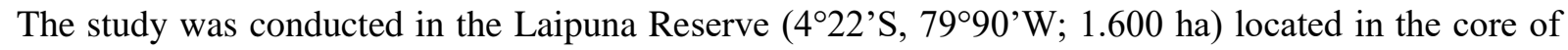
UNESCO "Bosque Seco" Biosphere Reserve in the Catamayo River canyon in southern Ecuador, which consists of a protected forest at altitudes between 600 and $1450 \mathrm{~m}$ asl. At low altitude, annual rainfall averages $540 \mathrm{~mm}$ with a considerable year-to-year variability (350-800 $\mathrm{mm} \mathrm{y}^{-1}$ between 2007 and 2014) (Suppl. Figure 3.1). The dry season lasts from mid-May to end of December. Also in the wet season dry spells are frequent. Higher altitudes receive an enhanced moisture input, partly from fog, due to moist air masses coming from the Pacific, and thus soil moisture increases with altitude. Annual mean temperature (at low altitude) is $23.7^{\circ} \mathrm{C}$ with little monthly variation (Pucha-Cofrep et al., 2015). Soils were classified as Cambisols with a high skeleton fraction (55\%). Mean slope angle is $18^{\circ}$ and aspect is north. The forest of the Laipuna Reserve is a closed forest (tree canopy cover $>40 \%$ ), has an average stem density of 410 stems $\mathrm{ha}^{-1}$ and basal area of $28.5 \mathrm{~m}^{2} \mathrm{ha}^{-1}$. At the lowest altitude stem density (320 stems $\mathrm{ha}^{-1}$ ) was lower than at the two higher altitudes (400 and 600 stems ha $^{-1}$ at 860 and $1100 \mathrm{~m}$ asl, 
respectively). Thirty-nine tree species were found in this forest, of which seven are evergreen and the remaining deciduous. The percentage of evergreen trees increased with altitude (Homeier, unpublished). The forest was described as premontane deciduous dry forest (Sierra, 1999; Aguirre et al., 2006).

\subsubsection{Studied tree species}

Four tree species were selected for this study: Ceiba trichistandra, Eriotheca ruizii, Erythrina velutina, and Capparis scabrida (Table 3.1). Ceiba is a leaf deciduous stem succulent species, Eriotheca is deciduous, and Capparis is an evergreen species. Erythrina has been found to be brevi-deciduous according to Cueva and Acarró (2011), but in our study region showed a similar leaf exchange behavior than the other deciduous species (despite its flowering during the dry season, which is a brevi-deciduous trait). Of the total stem density, Ceiba had a share of 4\%, Eriotheca of $13 \%$, Erythrina of $10 \%$, and Capparis of 2\% (Homeier, unpublished). Eriotheca and Erythrina were observed to flush leaves with the onset of the wet season at the end of January, Ceiba approximately one month earlier (Suppl. Figure 3.2). Leaf shedding in the three deciduous species usually occurs simultaneously at the end of the wet season, most frequently beginning of June. All four species have diffuse porous wood, with wood densities ranging from 0.27 (Ceiba, deciduous stem succulent) to $0.77 \mathrm{~g} \mathrm{~cm}^{-3}$ (Capparis, evergreen) (Zanne et al., 2009; Table 3.1). 
Table 3.1 Characteristics of the four studied tree species (mean $\pm \mathrm{SD}, \mathrm{n}=4$ trees per elevation), wood density taken from Zanne et al. 2009 .

\begin{tabular}{|c|c|c|c|c|c|c|c|c|c|c|}
\hline \multirow[t]{2}{*}{ Species } & \multirow[t]{2}{*}{ Family } & \multirow{2}{*}{$\begin{array}{l}\text { Leaf phenology/ } \\
\text { succulence }\end{array}$} & \multirow{2}{*}{$\begin{array}{l}\text { Foliation during } \\
\text { study period }\end{array}$} & \multirow[t]{2}{*}{ Wood density $\left(\mathrm{g} \mathrm{cm}^{-3}\right)$} & \multicolumn{3}{|c|}{$\mathrm{DBH}(\mathrm{cm})$} & \multicolumn{3}{|c|}{ Tree height (m) } \\
\hline & & & & & $670 \mathrm{~m}$ & $860 \mathrm{~m}$ & $1100 \mathrm{~m}$ & $670 \mathrm{~m}$ & $860 \mathrm{~m}$ & $1100 \mathrm{~m}$ \\
\hline Ceiba trichistandra & Malvaceae & $\begin{array}{l}\text { Deciduous/stem } \\
\text { succulent }\end{array}$ & Dec-Jun & 0.26 & $65.3 \pm 2.3$ & $69.9 \pm 3.1$ & $99.6 \pm 4.3$ & $16.9 \pm 3.3$ & $17.7 \pm 3.1$ & $18.9 \pm 4.3$ \\
\hline Eriotheca ruizii & Malvaceae & Deciduous & Jan-Jun & 0.47 & $39.4 \pm 2.1$ & $34 \pm 2.6$ & $44.4 \pm 3.3$ & $13.4 \pm 2.3$ & $10.7 \pm 2.4$ & $16.1 \pm 4.6$ \\
\hline Erythrina velutina & Leguminosae & Brevi-deciduous & Jan-Jun & 0.2 & $32.5 \pm 3.1$ & $28.6 \pm 3.7$ & $23.5 \pm 2.1$ & $13.2 \pm 1.9$ & $8.7 \pm 2$ & $7.8 \pm 1.3$ \\
\hline Capparis scabrida & Capparaceae & Evergreen & All year & 0.77 & $21.5 \pm 2.6$ & $18.7 \pm 2.3$ & n.a. & $8.9 \pm 1.6$ & $8.4 \pm 2.1$ & n.a. \\
\hline
\end{tabular}




\subsubsection{Sap flux}

Sap flux density was measured between April 2014 and June 2015 on 44 trees in total. Four trees of three species (Ceiba, Eriotheca, and Erythrina) were assessed at an elevation of 670 m, 860 m, and 1100 $\mathrm{m}$ asl. Capparis, however, was not found within reach and in sufficient number at the highest altitude, and was therefore only assessed at the low and mid elevation. Crowns of all study trees were exposed to full sunlight; stems were bigger than $15 \mathrm{~cm}$ in diameter (Table 3.1). At each altitude, the study trees were located at a maximum distance of $20 \mathrm{~m}$ from a central logger box. Thermal dissipation probes (TDP) after Granier (1987) were used, which consisted of a pair of probes with a diameter of $2 \mathrm{~mm}$ and a length of $20 \mathrm{~mm}$. Every tree was equipped with two sensors (one facing north, one facing south) at a height of $1.3 \mathrm{~m}$ above ground in the outermost xylem. Sensors were covered by Styrofoam boxes and reflective foil for protection. The upper probe of the sensor pair was continuously heated through a heating wire that was supplied with a constant power source of $120 \mathrm{~mA}$. The temperature difference between the two probes was measured every $30 \mathrm{~s}$ and averages were stored every $30 \mathrm{~min}$ (CR1000 data logger and AM 16/32 Multiplexer, Campbell Scientific, Inc., Logan, UT, United States). Temperature differences were converted to sap flux density $\left(\mathrm{J}_{\mathrm{s}} ; \mathrm{g} \mathrm{cm}^{-2} \mathrm{~h}^{-1}\right)$ per unit sap wood according to the original equation of Granier (1987). To assure the sap flux probes were installed fully within the high conducting sap wood (to avoid underestimation of flux according to Clearwater et al., 1999), radial sap flux profiles using heat field deformation (HFD) sensors were created.

\subsubsection{Radial sap flux profiles and whole tree water use}

Heat field deformation sensors (ICT International, Australia) were used to assess radial variation in sap flux density. An HFD sensor consisted of three needles each with eight measurement points spaced 1 $\mathrm{cm}$ apart from each other and one continuous heating element. The first needle was installed above (axial direction), the second besides (tangential direction), and the third underneath (axial direction) the heating element. A styrofoam spacer of $1 \mathrm{~cm}$ thickness was installed between the sensor needles and the tree, to assure that the first measurement point of the sensor's needle was directly located underneath the bark. Data was recorded every $30 \mathrm{~s}$ and averages stored every $30 \mathrm{~min}$. Six devices were used on the three species Ceiba, Eriotheca, and Erythrina at all altitudes and were shifted every three weeks, allowing each tree with TDP sensors to be monitored. Measurements were running during the whole wet season. HFD measurements failed in Capparis, for which, as a simple approximation Erythrina profiles were adopted (due to closest resemblances in crown structure, $\mathrm{DBH}$, and height). The profile data of mean daily sap flux density from the wet season was normalized to the depth of one centimeter to make it comparable to the data of the TDP method. These normalized values were fitted to a Gaussian function as this showed the best correlation to later calculate the volume of a rotated geometric solid (Oishi et al., 2008). Following this approach, radial changes in sap flux density were considered. The 
daily water use $\left(\mathrm{kg} \mathrm{day}^{-1}\right)$ of the sample trees was calculated by multiplying the TDP-derived daily sums of sap flux densities with the sap conducting area. The water conductive area for each tree was derived from tree diameter and the effective area of highly conducting sap wood recorded by HFD sensors. To derive individual tree water use rates, the respective water conducting areas were multiplied by the summed daily sap flux densities.

\subsubsection{Soil water content and air humidity}

Water content reflectometers (CS616, Campbell Scientific, Inc., Logan, UT, United States) were used to measure volumetric soil water content (SWC, \%) continuously at the three altitudes of sap flux measurements. Four probes were installed in a square of $4 \mathrm{~m} \times 4 \mathrm{~m}$ vertically at a depth of $0-30 \mathrm{~cm}$. Air temperature $\left({ }^{\circ} \mathrm{C}\right)$ and relative humidity $(\%)$ were measured at open conditions near the sap flux measurements at 860 and 1100 m asl (CS215, Campbell Scientific, Inc., Logan, UT, United States) and used to calculate vapor pressure deficit of the air (VPD, hPa). Air humidity data for the lowest study altitude had to be adopted from the mid elevation, as the actual measurements at $590 \mathrm{~m}$ asl. failed. Data was recorded every $30 \mathrm{~s}$, averaged over $30 \mathrm{~min}$, and stored in a CR1000 data logger.

\subsubsection{Data analysis and statistics}

Interactions of daily sap flux density with SWC, VPD, species, and altitude as fixed factors, tree size (DBH) as covariate, and individual tree ID (ID) as random effect were assessed by a mixed linear model (Model 1). The following two way interactions were included in the model: SWC:VPD, SWC:species, SWC:elevation, VPD:species, VPD:elevation and species:elevation. Assumption of normal distribution and homoscedasticity were tested and fulfilled. Relationships between sap flux density, diameter, and SWC were analyzed with linear regression, the relationship of sap flux density and VPD by logarithmic regression. For analyzing tree responses during dry and wet spells within the wet season (Figure 3.4, Figure 3.6), the respective period was split: a two week dry period was defined with soil water content $<15 \%$, and a two week wet period with soil water content $>25 \%$. Testing of significant differences between altitudes for monthly means of SWC was done by ANOVA with Tukey test in Table 3.2, likewise for maximum sap flux densities in Table 3.3. Diurnal hysteresis loops were used to display the relationship between sap flux density and VPD under wet and dry soil conditions. All statistical analyses were conducted with RStudio version 3.4.0 (R Development Core Team, 2008). For the analysis of the mixed linear models, the lme4 R package, version 1.15 by Bates et al. (2015) was used, for visualization of least square means of SWC and VPD trends the lsmeans R package, version 2.27-61 and for the fitted responses the sjPlot $\mathrm{R}$ package, version 2.4.1. The $\mathrm{R}^{2}$ for the mixed effect model was calculated according to Nakagawa and Schielzeth (2012) with the MuMln R package, version 1.40.4. 


\subsection{Results}

\subsubsection{Soil water content}

Soil water content varied with season and altitude. At the mid elevation (860 m asl.) lowest SWC was recorded in December 2014 at the end of the dry season (monthly mean 5.7\%), and highest during the wet season in April 2015 (monthly mean 25.9\%, p < 0.05) (Table 3.2). Along the altitudinal gradient SWC increased with increasing elevation; e.g., in March 2015 the monthly mean SWC was 19.1\% at the lowest, $24.7 \%$ at the middle, and $33.9 \%$ at the highest altitude ( $p<0.05$, respectively). Also within the wet season, SWC was variable over time (Figure 3.1). 
Table 3.2 Soil water content (SWC, \%) in the study period at three altitudes ( $\mathrm{n}=4$ reflectometer probes at 0-30 $\mathrm{cm}$ depth, mean $\pm \mathrm{SD}$ ), monthly means were tested across altitudes and across month with ANOVA followed by Tukey test. The lower case letters indicate statistical differences $(p<0.05)$ between altitudes, the upper case letters between months.

\begin{tabular}{lccccccccc}
\hline Month & \multicolumn{3}{c}{$670 \mathrm{~m}$ asl. } & \multicolumn{3}{c}{$860 \mathrm{~m}$ asl. } & & \multicolumn{2}{c}{$1100 \mathrm{~m}$ asl. } \\
\hline & Min & Mean & Max & Min & Mean & Max & Min & Mean & Max \\
\cline { 2 - 8 } Dec-14 & $5.1 \pm .9$ & $5.5 \pm 2.2^{\mathrm{aA}}$ & $5.9 \pm 1.1$ & $4.5 \pm 1.9$ & $5.7 \pm 2.1^{\mathrm{aA}}$ & $6.1 \pm 1.5$ & $8.5 \pm 2.1$ & $9.5 \pm 2.2^{\mathrm{bA}}$ & $12.3 \pm 3$ \\
Jan-15 & $5.4 \pm 1.2$ & $6.2 \pm 3.4^{\mathrm{aA}}$ & $15.7 \pm 1.4$ & $7.6 \pm 1$ & $9.2 \pm 3.9^{\mathrm{aB}}$ & $18.9 \pm 2.6$ & $14.5 \pm 2$ & $18 \pm 4.5^{\mathrm{bB}}$ & $30.8 \pm 4.5$ \\
Feb-15 & $5.2 \pm 2$ & $8.8 \pm 3.9^{\mathrm{aA}}$ & $18.6 \pm 5.5$ & $7.3 \pm 1.9$ & $14.1 \pm 4.9^{\mathrm{abB}}$ & $22.7 \pm 5$ & $14.4 \pm 2.7$ & $23.9 \pm 5.9^{\mathrm{bB}}$ & $34.1 \pm 5.6$ \\
Mar-15 & $5.9 \pm .7$ & $19.1 \pm 4.6^{\mathrm{aB}}$ & $31.9 \pm 4.9$ & $8.6 \pm 1.2$ & $24.7 \pm 5.6^{\mathrm{bC}}$ & $36.1 \pm 4.3$ & $14.3 \pm 3.1$ & $33.9 \pm 5.9^{\mathrm{cC}}$ & $40.2 \pm 5.8$ \\
Apr-15 & $16.4 \pm 2.5$ & $23.9 \pm 4.7^{\mathrm{aB}}$ & $30.5 \pm 4.2$ & $20.1 \pm 3$ & $25.9 \pm 5.3^{\mathrm{abC}}$ & $35.4 \pm 4.9$ & $25.9 \pm 4.2$ & $33.7 \pm 3.9^{\mathrm{bC}}$ & $40.3 \pm 6$ \\
May-15 & $6.1 \pm 1.1$ & $9.8 \pm 3.7^{\mathrm{aAB}}$ & $23.8 \pm 2.9$ & $10.4 \pm 1.1$ & $12.3 \pm 4.4^{\mathrm{aBC}}$ & $28.6 \pm 3.7$ & $14.6 \pm 2.3$ & $20.3 \pm 3.9^{\mathrm{bB}}$ & $32.3 \pm 4.5$ \\
Jun-15 & $9.3 \pm 1.5$ & $12.1 \pm 3.2^{\mathrm{aAB}}$ & $18.5 \pm 2.8$ & $14.3 \pm 2$ & $15.1 \pm 3.8^{\mathrm{aB}}$ & $22.9 \pm 3.4$ & $25 \pm 4.7$ & $27.52 \pm 2.3^{\mathrm{bB}}$ & $32.5 \pm 5.8$ \\
\hline
\end{tabular}




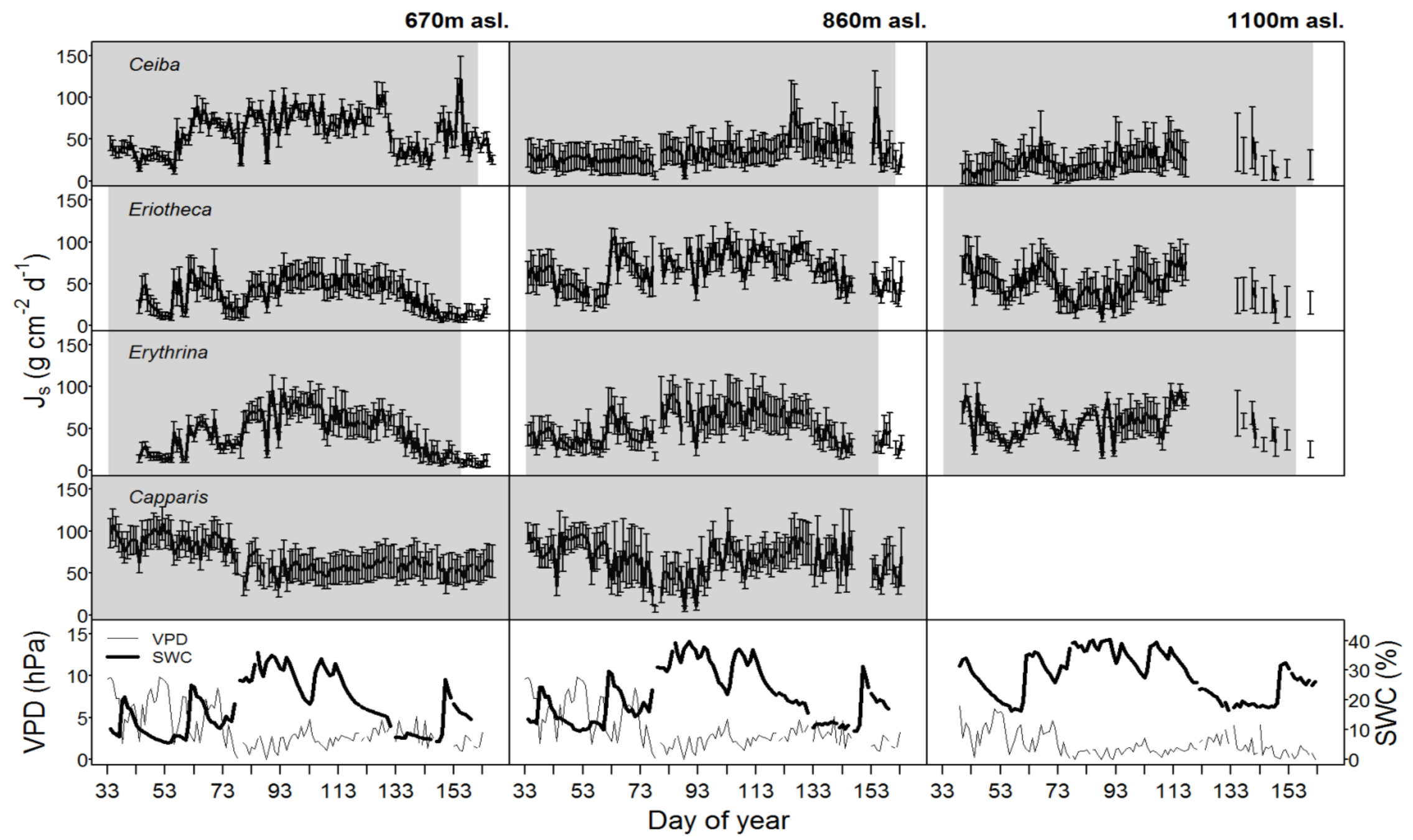

Figure 3.1 Daily sap flux densities $\left(\mathrm{J}_{\mathrm{s}}\right)(\mathrm{n}=4$ trees per elevation) of the four study species as well as vapor pressure deficit (VPD, values at $670 \mathrm{~m}$ were adopted from $860 \mathrm{~m}$ asl.) and soil water content (SWC) over the whole study period in the year 2015, grey shaded area indicates foliated period, error bars indicate standard $\checkmark$ deviation. 


\subsubsection{Sap flux in the rainy season}

Species, altitude, tree water use

Maximal sap flux densities $\left(\mathbf{J}_{\text {smax }}\right)$ in the outer xylem varied from $3.1 \mathrm{~g} \mathrm{~cm}^{-2} \mathrm{~h}^{-1}$ (Erythrina at low altitude and dry soil) to $15.9 \mathrm{~g} \mathrm{~cm}^{-2} \mathrm{~h}^{-1}$ (Eriotheca at middle altitude and moist soil) (Table 3.3). Characteristic sap flux patterns under moist soil conditions on sunny days were similar between species and differed solely in magnitude (Suppl. Figure 3.4, Suppl. Figure 3.3). At the same altitude and between dry and wet soil, $\mathrm{J}_{\text {smax }}$ of Ceiba, Eriotheca, and Erythrina tended to be enhanced, whereas Capparis showed little difference. Seasonal sap flux density of all species followed fluctuations of the two main environmental drivers SWC and VPD (Figure 3.1). Radial variation in sap flux density of Ceiba displayed a humpedshaped curve with maximum flux densities at $1-3 \mathrm{~cm}$ beneath cambium and lower values at the outermost xylem (Suppl. Figure 3.4). Eriotheca in contrast had highest flux densities directly underneath the bark in the outer most xylem, whereas for Erythrina highest flux densities were recorded at a depth of $1 \mathrm{~cm}$. On sunny days at high soil moisture, whole-tree water use increased linearly with increasing tree diameter $\left(\mathrm{R}^{2}=0.67, \mathrm{p}<0.001\right)$ (Figure 3.2), displaying a clear scaling relationship for all species. Highest water use of $140 \mathrm{~kg} \mathrm{day}^{-1}$ was estimated for a Ceiba tree with a diameter at breast height of $133 \mathrm{~cm}$.

Table 3.3 Maximum sap flux densities under dry and wet soil conditions. Two weeks' period in the 2015 rain period with low $(<15 \%)$ and high $(>25 \%)$ soil water content $($ SWC). $\mathrm{n}=4$ trees per species, mean \pm SD. Maximum sap flux densities were tested using ANOVA followed by Tukey test. Letters indicate significant difference $(\mathrm{p}<0.05)$ between SWC, altitude and species.

\begin{tabular}{lllllll}
\hline \multicolumn{7}{c}{$\mathrm{J}_{\text {smax }}\left(\mathrm{g} \mathrm{cm}^{-2} \mathrm{~h}^{-1}\right)$} \\
\hline Species & \multicolumn{2}{c}{$670 \mathrm{~m}$ asl } & \multicolumn{2}{c}{$860 \mathrm{~m}$ asl } & \multicolumn{2}{c}{$1100 \mathrm{~m}$ asl } \\
& SWC $<15$ & $\mathrm{SWC}>25$ & $\mathrm{SWC}<15$ & $\mathrm{SWC}>25$ & $\mathrm{SWC}<15$ & $\mathrm{SWC}>25$ \\
\hline Ceiba & $5.8 \pm 2.3^{\mathrm{a}}$ & $15 \pm 4.5^{\mathrm{b}}$ & $5.5 \pm 1.5^{\mathrm{a}}$ & $10.7 \pm 3.8^{\mathrm{b}}$ & $12.7 \pm 5^{\mathrm{b}}$ & $14.8 \pm 6.1^{\mathrm{b}}$ \\
Eriotheca & $5.8 \pm 3^{\mathrm{a}}$ & $7.8 \pm 4.1^{\mathrm{a}}$ & $4.8 \pm 1.6^{\mathrm{a}}$ & $15.9 \pm 5.2^{\mathrm{b}}$ & $7.3 \pm 2.9^{\mathrm{a}}$ & $9.9 \pm 4.8^{\mathrm{b}}$ \\
Erythrina & $3.1 \pm 2^{\mathrm{a}}$ & $12 \pm 3.7^{\mathrm{b}}$ & $3.8 \pm 1.8$ & $15 \pm 5.6^{\mathrm{b}}$ & $6.3 \pm 2.1^{\mathrm{a}}$ & $12.2 \pm 5.7^{\mathrm{b}}$ \\
Capparis & $15.3 \pm 4.8^{\mathrm{b}}$ & $13.3 \pm 5.7^{\mathrm{b}}$ & $12.2 \pm 2.6^{\mathrm{b}}$ & $10.1 \pm 3^{\mathrm{b}}$ & n.a. & n.a. \\
\hline
\end{tabular}




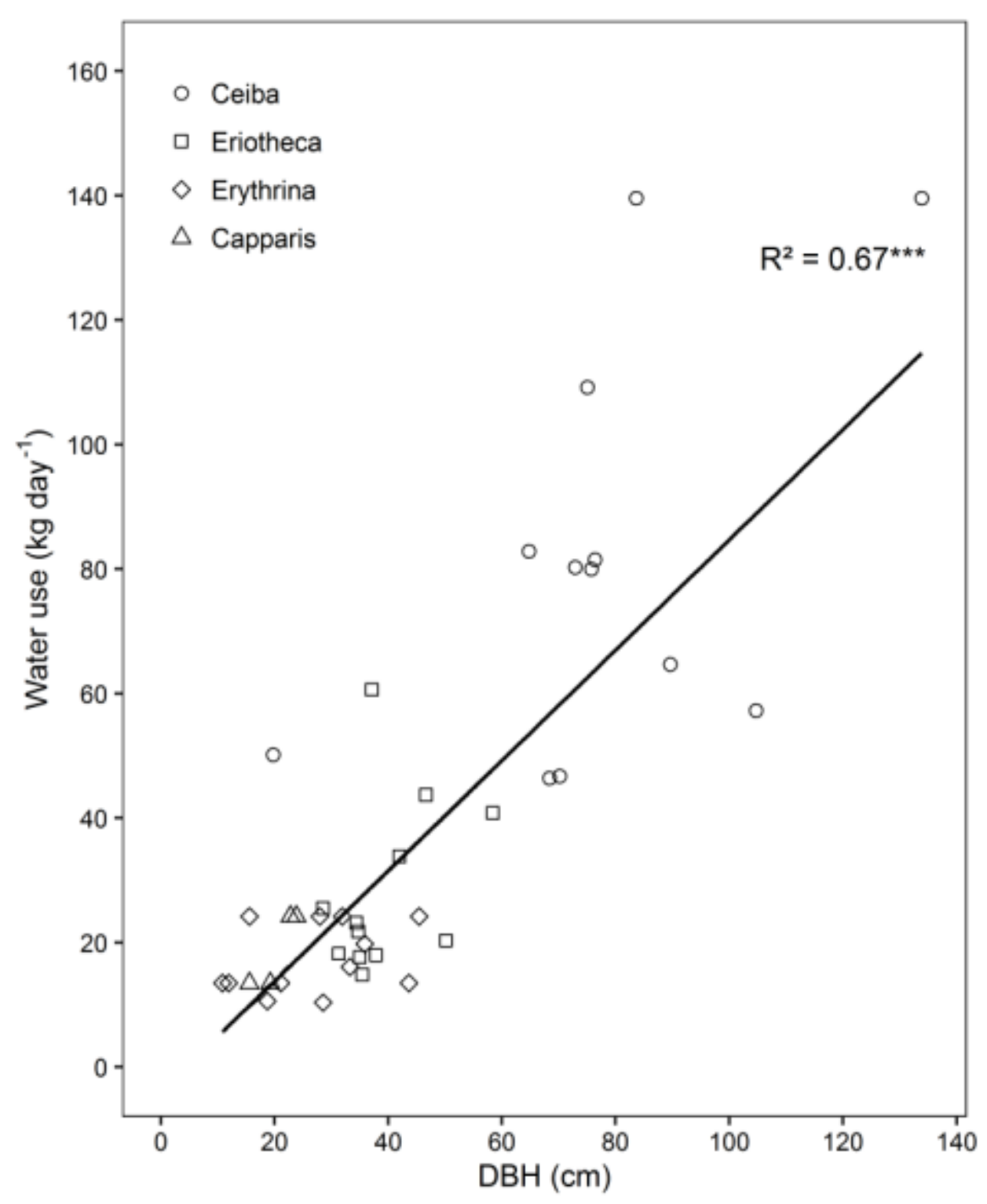

Figure 3.2 Relationship between mean daily tree water use and tree diameter (DBH), $n=40, p<0.001$.

The results of the ANOVA from Model 1 (interactions of the response variable sap flux density with the independent variables SWC, VPD, species, altitude, and DBH) showed significant relationships for daily sap flux density and VPD ( $<<0.0001)$, species ( $<<0.05)$, elevation $(\mathrm{p}<0.0001)$, and DBH $(\mathrm{p}<$ 0.05) (Table 3.4). Significance was also found for the following two-way interactions: SWC:VPD (p < 0.0001), SWC:species ( $<<0.0001)$, SWC:elevation ( $<<0.0001)$, VPD:elevation $(\mathrm{p}<0.001)$ and VPD:species $(\mathrm{p}<0.0001)$. Overall the model explained $39 \%$ of the marginal variance $\left(\mathrm{R}^{2}=0.39\right.$, fixed effects only), and $56 \%$ of the conditional variance $\left(\mathrm{R}^{2}=0.56\right.$, including the random effect). The visualization of the fitted responses of the fixed effects from Model 1 proved the strong influence of the environmental drivers (SWC and VPD) on sap flux density (Suppl. Figure 3.5). The impact differed between species and altitude. Capparis showed low sap flux sensitivity to SWC, but the highest sensitivity to VPD (Figure 3.3). This was reflected in decreasing sap flux density with increasing SWC in contrast to a more intense VPD response (Suppl. Figure 3.5). The two deciduous species (Eriotheca, 
Erythrina) showed the contrary reaction patterns, indicating a stronger control of SWC than VPD. Stem succulent Ceiba showed for both, SWC and VPD similar sensitivity, making it the most moderate species in the setup (Figure 3.3). Under generally higher SWC at the highest plot, Ceiba and Eriotheca were able to increase sap flux density with increasing VPD (Suppl. Figure 3.5). 
Table 3.4 Anova table from mixed linear Model 1 (mixed effects model) with main effects of soil water content (SWC), vapor pressure deficit (VPD), species, elevation as fixed effects, tree size (DBH) as covariate and species identity as random effect on daily sap flux density for the whole study period. The following two way interactions: SWC:species, SWC:elevation, species:elevation, VPD:species, VPD:elevation and SWC:VPD were included. Significance codes: $\mathrm{p}<0.0001$ '***', $\mathrm{p}<0.001^{\prime * * ',} \mathrm{p}<0.01^{\prime *}, \mathrm{p}<0.5^{\prime} . ', \mathrm{p}<0.1^{\prime \prime}$.

\begin{tabular}{|c|c|c|c|c|c|c|c|}
\hline & Sum Sq & Mean Sq & NumDF & DenDF & F.value & $\operatorname{Pr}(>\mathrm{F})$ & \\
\hline SWC & 0.7747 & 0.7747 & 1 & 985.89 & 3.289 & 0.070039 & \\
\hline VPD & 6.2923 & 6.2923 & 1 & 984.39 & 26.715 & $2.86 \mathrm{E}-07$ & $* * *$ \\
\hline Elevation & 6.949 & 3.4745 & 2 & 248.78 & 14.751 & 8.83E-07 & $* * *$ \\
\hline DBH & 1.637 & 1.637 & 1 & 27.06 & 6.95 & 0.013712 & $*$ \\
\hline species:elevation & 1.9887 & 0.3977 & 5 & 27.23 & 1.689 & 0.17104 & \\
\hline VPD:species & 6.4311 & 2.1437 & 3 & 984.12 & 9.101 & $6.04 \mathrm{E}-06$ & $* * *$ \\
\hline VPD:elevation & 3.0612 & 1.5306 & 2 & 983.91 & 6.498 & 0.001571 & $* *$ \\
\hline SWC:VPD & 14.4382 & 14.4382 & 1 & 984.96 & 61.299 & $1.27 \mathrm{E}-14$ & $* * *$ \\
\hline
\end{tabular}



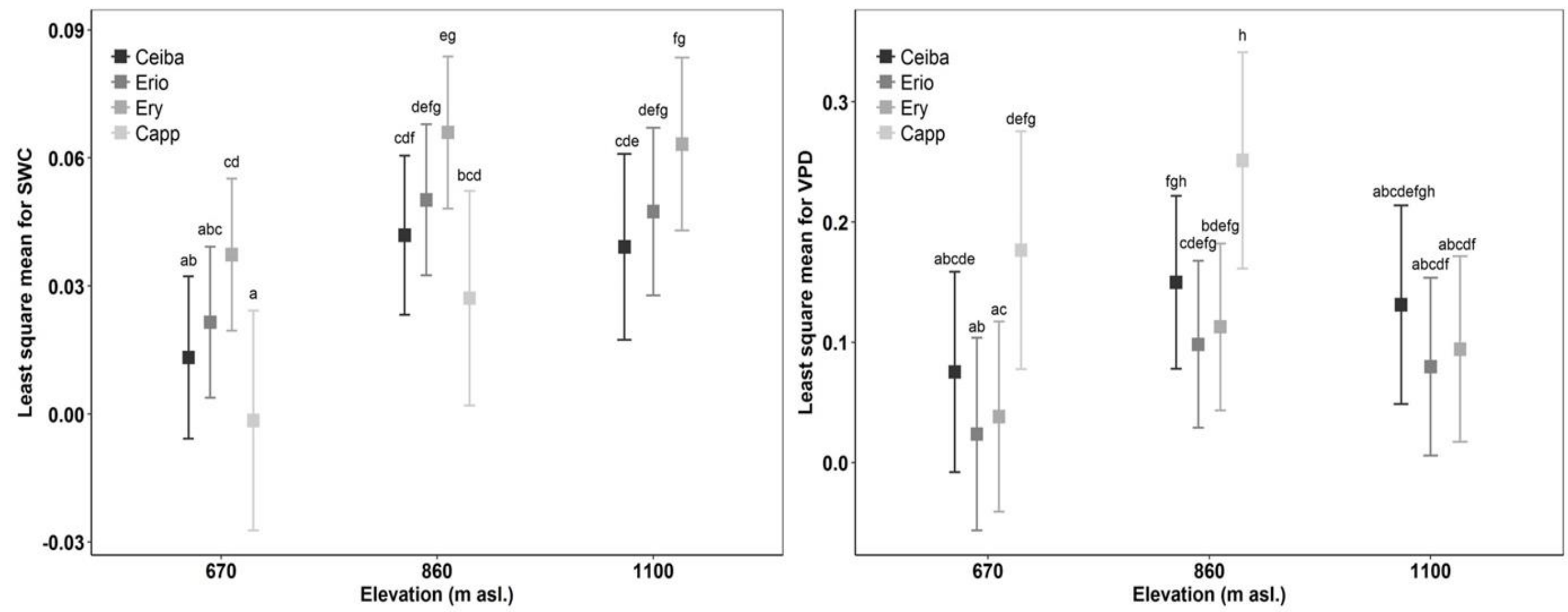

Figure 3.3 Comparison of sap flux density response to SWC and VPD for species over elevation to measure sap flux sensitivity in accordance with environmental drivers, boxes indicate least-squares means, error bars indicate 95\% confidence interval of the least square means. Means sharing a letter are not significantly different (Tukey-adjusted comparison). 


\subsubsection{Day to day responses to soil moisture variations}

Sap flux density increased linearly with increasing soil moisture in the deciduous species Ceiba, Eriotheca, and Erythrina. This trend was most pronounced at the lowest elevation (Ceiba $\mathrm{R}^{2}=0.28, \mathrm{p}$ $<0.001$, Eriotheca $\mathrm{R}^{2}=0.2, \mathrm{p}<0.001$ and Erythrina $\mathrm{R}^{2}=0.43, \mathrm{p}<0.001$, Figure 3.4), and partly vanished at higher altitudes. The evergreen Capparis in contrast showed a linear decrease of sap flux density with increasing soil moisture at 670 and $860 \mathrm{~m}$ asl., this was also found for Eriotheca at $1100 \mathrm{~m}$ asl for high SWC values (> 30\%). To further verify these findings, the least-squares means for SWC, species, altitude, and sap flux density (Model 1) were analyzed (Figure 3.3). Significant differences between deciduous and evergreen species in sap flux density were found for Erythrina and Capparis (p $<0.05)$ at $670 \mathrm{~m}$ and $860 \mathrm{~m}$ asl. with a similar trend for the other species. Erythrina showed at all altitudes the highest sensitivity towards SWC. Further significant differences in sap flux density among species across altitudes were found for the study site at $670 \mathrm{~m}$ asl. (significantly different for all species from 860 and $1100 \mathrm{~m}$ asl., p < 0.05) (Figure 3.3). This indicated a higher sensitivity of sap flux towards SWC for the deciduous species. 
$670 \mathrm{~m}$ asl.

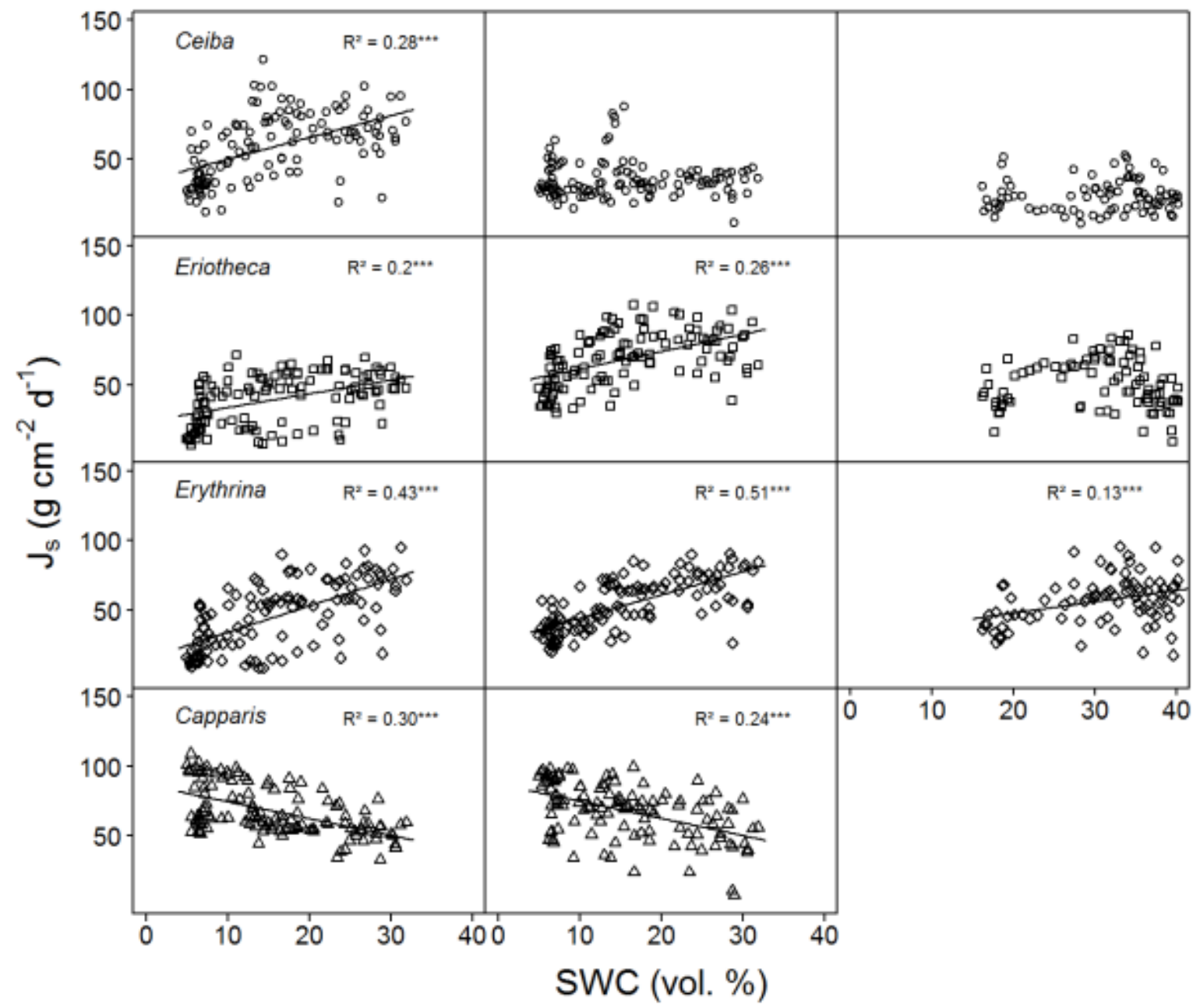

Figure 3.4 Daily sap flux densities $\left(\mathrm{J}_{\mathrm{s}}\right)$ of the four study species versus daily soil water content (SWC).

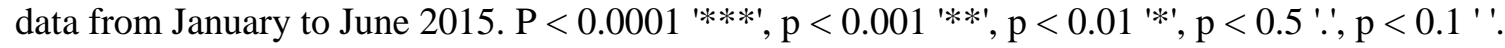

For two contrasting soil moisture levels $(<15 \%,>25 \%)$, all deciduous species showed a decrease of sap flux density under dry conditions. Capparis in contrast increased sap flux density (Table 3.3). The three deciduous species increased sap flux densities with increasing VPD at moist soil conditions (Figure 3.5). Under dry conditions the increase was much less pronounced (resulting in lower $\mathrm{R}^{2}$ and $\mathrm{p}$ values) or even turned into a slight decrease. At higher elevation and under dry conditions the correlations of sap flux density and VPD for Eriotheca and Erythrina disappeared, whereas for the stem succulent Ceiba a strong correlation was detected. As a general trend, the deciduous species displayed increasing sap flux densities with increasing VPD under wet conditions, whereas under dry conditions sap flux densities remained at low levels even with increasing VPD. However, this pattern lessened with increasing altitude. Especially under dry soil moisture levels sap flux densities of the evergreen Capparis showed strong positive correlations to VPD (adj. $\mathrm{R}^{2}=0.75$ and $0.8, \mathrm{p}<0.001$, respectively at 670 and $860 \mathrm{~m}$ asl.). Plotting the least squares means for VPD against species and altitude for sap flux density (Model 1) over the whole study period showed a significant difference of Eriotheca and Erythrina (low 
sensitivity towards VPD) from Capparis (high sensitivity) $(\mathrm{p}<0.05)$ at 670 and at $860 \mathrm{~m}$ asl. (Figure 3.3). Significant difference in sap flux density within species was also recorded for all species between the altitudes of 670 and $860 \mathrm{~m}$ asl. $(\mathrm{p}<0.05)$ (Figure 3.3).

$670 \mathrm{~m}$ asl. $\quad 860 \mathrm{~m}$ asl.

$1100 \mathrm{~m}$ asl.

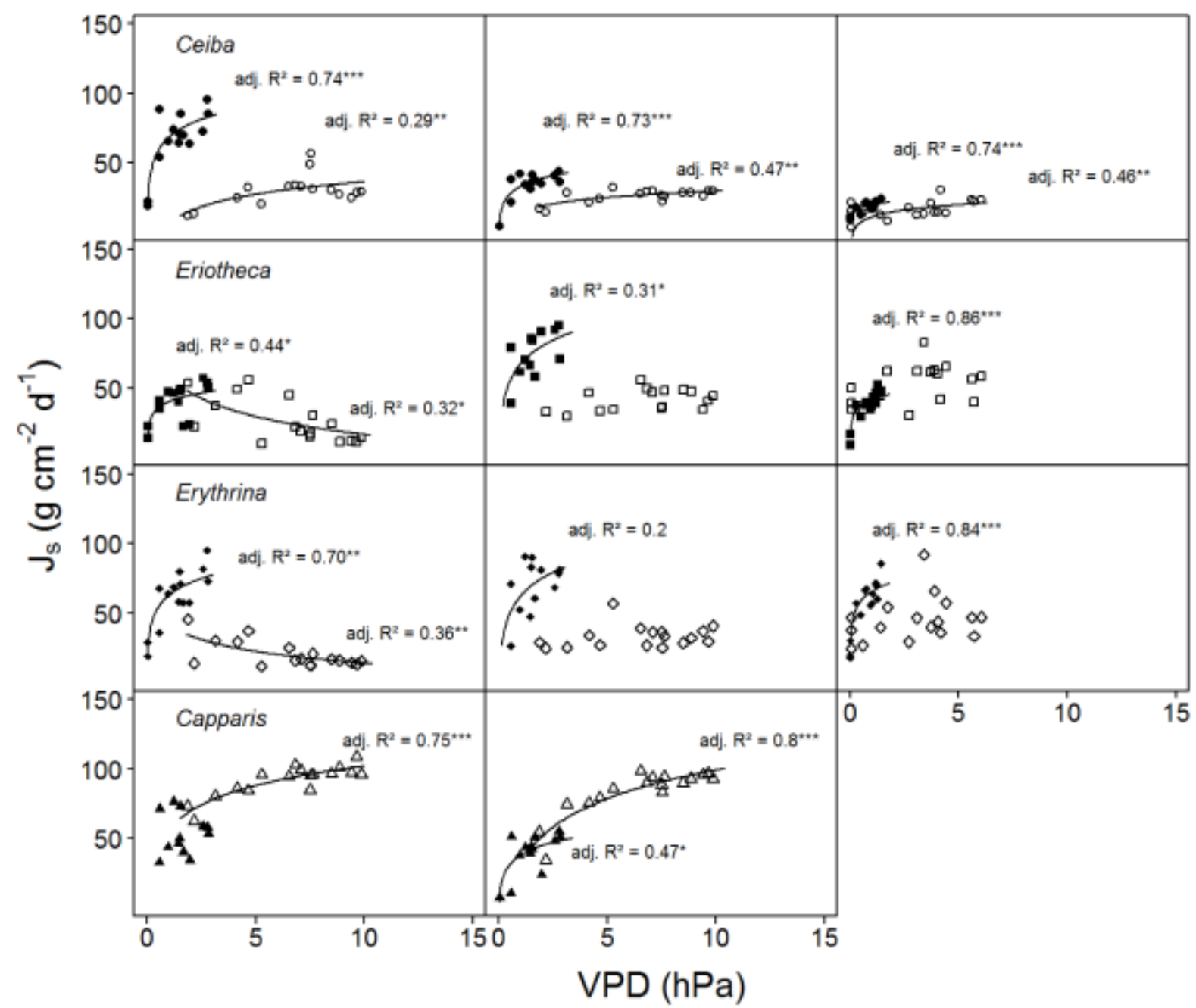

Figure 3.5 Daily sap flux densities $\left(\mathrm{J}_{\mathrm{s}}\right)$ of the four study species plotted against average daily VPD. Filled symbols indicate wet conditions (SWC > 25\%), open symbols dry conditions (SWC < 15\%) (data from two weeks per period). Logarithmic regressions were fitted to the data. $\mathrm{P}<0.0001^{\prime} * * * ', \mathrm{p}<0.001$ '**', $\mathrm{p}<0.01^{\prime} *$ ', $\mathrm{p}<0.5^{\prime} ., \mathrm{p}<0.1^{\prime}$ ', $\mathrm{R}^{2}$ is given in italics. Daily sap flux densities derived from measurements of $\mathrm{n}=$ four individuals per species per altitude and treatment.

\subsubsection{Diurnal hysteresis at dry and moist soil}

On a day with relatively high soil water content (26\%), the four studied species showed similar diurnal relationship between sap flux density and VPD (Figure 3.6). Sap flux density rose in the morning with increasing VPD, peaked before maximum VPD around noon, and then ran back over the course of the remaining day, forming the hysteresis area. The direction of rotation was clockwise in all species. 
Capparis peaked at $11.30 \mathrm{am}$, Ceiba and Eriotheca at 12:30 pm, and Erythrina was the last to culminate at 13:30 pm, close to the peak of the daily VPD at 15:30 pm.

On a day with low soil water content (7\%), the area of the hysteresis loop for the evergreen Capparis was enhanced, whereas it was much smaller for the deciduous species. Furthermore, the peaks of sap flux density shifted to $12: 30 \mathrm{pm}$ for the evergreen Capparis, and to $15: 30 \mathrm{pm}$ for the three deciduous species (Figure 6).

$670 \mathrm{~m}$ asl.

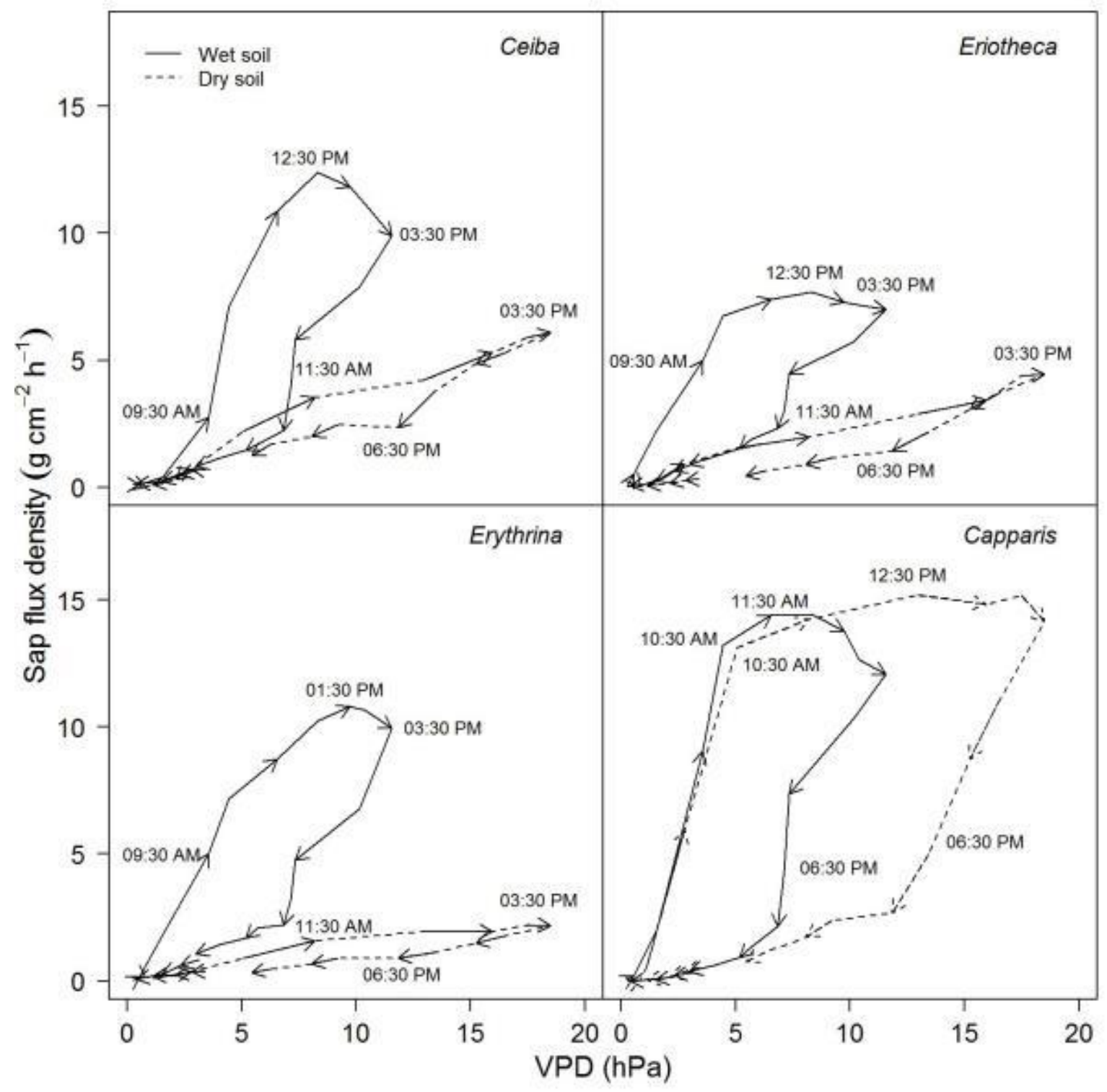

Figure 3.6 Diurnal hysteresis loops showing the relationship between hourly sap flux density and VPD for dry $(16.02 .2015, \mathrm{SWC}=7.4 \%)$ and wet $(13.04 .2015, \mathrm{SWC}=25.8 \%)$ soil conditions. Solid line indicates wet conditions, dashed line dry conditions; arrows show direction of rotation with time of the day. Hourly averages were derived from simultaneous measurement of $n=4$ trees on a sunny day. 


\subsubsection{Sap flux in the dry period}

In the dry season the evergreen species Capparis displayed sap flux densities comparable to the wet season, but sap flux in the defoliated deciduous species was close to zero (Suppl. Figure 3.6).

In 2014, some anomalies in precipitation patterns were recorded, with a low rainfall volume in April (18 $\mathrm{mm}$ ) but $70 \mathrm{~mm}$ of rainfall in early May. All three deciduous species had shed their leaves by end of April; most Eriotheca and Erythrina remained defoliated until January 2015. Some Ceiba individuals, however, re-flushed and maximal sap flux densities of 5-8 $\mathrm{g} \mathrm{cm}^{2} \mathrm{~h}^{-1}$ were measured (Suppl. Figure 3.7). Also some Erythrina trees re-flushed but sap flux data are not available.

\subsection{Discussion}

The four studied tree species showed distinct patterns in water use and its response to changes in soil moisture. Maximum sap flux densities were medium to low when compared to other tree species from tropical dry forests (Kume et al., 2007; Goldstein et al., 2008; Reyes-García et al., 2012). This might be due to the fact that the other studies were characterized by higher VPDs ( $15 \mathrm{hPa}$ vs. $30 \mathrm{hPa}$ ) and therefore high demanding conditions for transpiration. Under favorable conditions, daily tree water use increased with tree diameter, which has already been found in many other studies (e.g., James et al., 2003; Meinzer et al., 2005; Kunert et al., 2012), whereas under dry conditions this relation became weaker $\left(\mathrm{R}^{2}=0.51\right.$, $\mathrm{p}<0.0001$, data not shown). Small statured trees including the evergreen Capparis had daily water use rates of less than $20 \mathrm{~kg} \mathrm{day}^{-1}$, whereas the stem succulent Ceiba reached water use rates of about $140 \mathrm{~kg}$ day $^{-1}$. Accordingly, Ceiba displayed a radial flux profile with the biggest area where maximum sap flux was located at $2 \mathrm{~cm}$ depth, protected by the outer low-conducting xylem. Temporal changes in SWC across the altitudinal gradient influenced sap flux of the species differently. The deciduous species reduced sap flux sensitively, even when in leaves, which was not observed for the evergreen species Capparis.

The particular response in sap flow to top soil water decrease by the evergreen Capparis points to access to wetter, deeper soil by deep reaching roots. Under those conditions species like Capparis lean towards adaptations that maximize deeper soil water use (large root:shoot ratio, predominantly deep root system, lower leaf conductance with low stomatal sensitivity; Schwinning and Ehleringer, 2001). In this context the application of stable isotopes would be an important addition to access soil water depths (Ehleringer and Dawson, 1992). Thus based on the phenology and immediate drought response Capparis can be classified a drought tolerant species according to the criteria described by Ogburn and Edwards (2010). The considerable reduction in sap flux density in response to soil water decrease of the deciduous (nonstem succulent) Eriotheca and Erythrina may be explained by increased stomata control. This was also reflected by the influence of VPD on sap flux, since both species had significantly lower values than the 
evergreen Capparis. Therefore, both species can be classified as drought avoiding according to Ogburn and Edwards (2010).

The deciduous, stem succulent Ceiba had high water use rates under favorable conditions and much reduced sap flux densities when soil moisture was low. Herein the role of the big stem is of particular interest as the water storage mechanism was suspected to serve as buffer to allow for daily transpiration even under non-favorable conditions. Using dendrometer bands in a previous study, it was shown that the Ceiba stem decreased in circumference when the soil dried out and swiftly increased after rain events (Butz et al., 2017). For stem deciduous, stem succulent baobab trees (Adansonia spp.) in Madagascar, studies by Chapotin et al. (2006b) indicated that stem water storage was not used for maximizing stomatal opening and hence water use. In our study and for Ceiba we cannot differentiate whether water first goes into the storage and thereafter is used for transpiration or address the residence time of the water in the stem. It seems that Ceiba does both when water is available: increase the stem volume, most likely by increasing its water content, and transpire at high rates. We observed a reduction in sap flux accompanied by a decrease in stem circumference when soil dried out (Butz et al., 2017). Some internally stored water seemed to be used for maintaining a relatively high transpiration rate under drying soil conditions. However, transpiration was also sensitively reduced; further the strong difference between the hysteresis loops and dry and wet soil conditions underlined this strong reduction in sap flux. Only Capparis was able to enhance sap flux rates under drier conditions (decreased SWC, increasing VPD), indicating once more the access to deeper soil water reserves and potentially stronger stomatal control (to keep the stomata opened). The deciduous species were not able to keep sap flux rates stable. We recorded leaf flush of Ceiba approximately one month before the onset of the wet season under very dry soil water conditions and a subsequent decrease in stem circumference (Butz et al., 2017). Hence, there is some water stored in the stem over several months to enable leaf flushing. Chapotin et al. (2006a) suggested that baobabs use stored stem water to flush new leaves at the end of the dry season, just before the onset of the wet season. In this respect Ceiba and baobab seem to be similar. Also after rain events in the early dry season Ceiba flushed new leaves but sap flux densities remained relatively low. This contrast with results from an irrigation experiment in Costa Rica (Borchert et al., 2002) in which the deciduous, stem succulent species did not re-flush but remained dormant. The re-flush of Ceiba may as well be related to the fact that the intermittent rainfall event took place very early in the dry season. Trees probably were not yet dormant and thus re-flush was still under exogenous instead of endogenous control (Borchert, 1994b).

To summarize, we adopt an approach by Schwinning and Ehleringer (2001) developed for desert plants. The relation of water use to water availability in the four tree species is: (i) evergreen trees with particular response to soil drought, most likely with access to deep soil water (Capparis), (ii) deciduous trees with modest daily water use rates and strong reduction of sap flux in response to soil drought, but no large stem water storage (Eriotheca and Erythrina), and (iii) deciduous, stem succulent trees with 
high water use under favorable conditions, sensitive reduction of sap flux with soil moisture decline, responsive to short and strong rain events, and early re-flush at the end of the dry season based on water stored in the stem (Ceiba). The study thus indicates a strong influence of species' drought coping strategy on water use patterns in tropical dry forests.

\section{Acknowledgements}

We thank the Ecuadorian Ministry of the Environment (MAE) for the research permission and Nature and Culture International (NCI) for logistic support. We further acknowledge the comments of the two reviewers, which greatly helped to improve the manuscript 


\section{$3.5 \quad$ References Chapter 3}

Aguirre, Z., Linares-Palomino, R., Kvist, L. P., 2006. Especies leñosas y formaciones vegetales en los bosques estacionalmente secos de ecuador y perú. Arnaldoa 13, 324-346.

Allen, K.J., Dupuy, M., Gei, M.G., Hulshof, C., Medvigy, D., Pizano, C., Salgado-Negret, B., Smith, C.M., Trierweiler, A., Van Bloem, S.J., Waring, B.G., Xu, X., Powers, J.S., 2017. Will seasonally dry tropical forests be sensitive or resistant to future changes in rainfall regimes? Environ. Res. Lett. 12. doi: 10.1088/1748-9326/aa5968

Bastin, J.F., Berrahmouni, N., Grainger, A., Maniatis, D., Mollicone, D., Moore, R., Patriarca, C., Picard, N., Sparrow, B., Abraham, E.M., Aloui, K., Atesoglu, A., Attore, F., Bassüllü, Ç., Bey, A., Garzuglia, M., García-Montero, L.G., Groot, N., Guerin, G., Laestadius, L., Lowe, A.J., Mamane, B., Marchi, G., Patterson, P., Rezende, M., Ricci, S., Salcedo, I., Sanchez-Paus Diaz, A., Stolle, F., Surappaeva, V., Castro, R., 2017. The Extent of Forest in Dryland Biomes. Science 356. https ://635-638. 10.1126/science.aam6527Bates, D., Maechler, M., Bolker, B., and Walker, S. (2015). Fitting linear mixed-effects models using lme4. J. Stat. Softw. 67, 1-48. doi: $10.18637 /$ jss. v067.i01

Borchert, R., 1994a. Induction of rehydration and bud break by irrigation or rain in deciduous trees of a tropical dry forest in Costa Rica. Trees 8, 198-204. doi: 10.1007/BF00196847

Borchert, R., 1994b. Soil and stem water storage determine phenology and distribution of tropical dry forest trees. Ecology 75, 1437-1449. doi: 10.2307/1937467

Borchert, R., 1996. Phenology and flowering periodicity of neotropical dry forest species: evidence from herbarium collections. Trop. Ecol. 12, 64-80. doi: 10.1017/S0266467400009317

Borchert, R., 1998. Responses of tropical trees to rainfall seasonality and its long-term changes. Clim. Change 39, 381-393. doi: 10.1023/A:1005383020063

Borchert, R., Rivera, G., Hagnauer, W., 2002. Modification of vegetative phenology in a tropical semideciduous forest by abnormal drought and rain. Biotropica 34, 27-39. doi: 10.1111/j.17447429.2002.tb00239

Butz, P., Raffelsbauer, V., Graefe, S., Peters, T., Cueva, E., Hölscher, D., Bräuning, A., 2017. Tree responses to moisture fluctuations in a neotropical dry forest as potential climate change indicators. Ecol. Indic. 83, 559-571. doi: 10.1016/j.ecolind.2016.11.021

Carrasco, L.O., Bucci, S.J., Francescantonio, D.D., Lezcano, O.A., Campanello, P.I., Scholz, F.G., Rodríguez, S., Madanes, N., Cristiano, P.M., Hao, G.Y., Holbrook, N.M., Goldstein, G., 2014. Water storage dynamics in the main stem of subtropical tree species differing in wood 
density, growth rate and life history traits. Tree Physiol. 35, 354-365. doi: 10.1093/treephys/tpu087

Chapotin, S.M., Razanameharizaka, J.H., Holbrook, N.M., 2006a. Baobab trees (Adansonia) in Madagascar use stored water to flush new leaves but not to support stomatal opening before the rainy season. New Phytol. 169, 549-559. doi: 10.1111/j.1469-8137.2005.01618.x

Chapotin, S.M., Razanameharizaka, J.H., Holbrook, N.M., 2006b. Water relations of baobab trees (Adansonia spp. L.) during the rainy season: does stem water buffer daily water deficits? Plant Cell Environ. 29, 1021-1032. doi: 10.1111/j.1365-3040.2005.01456.x

Clearwater, M.J., Meinzer, F.C., Andrade, J.L., Goldstein, G., Holbrook, M., 1999. Potential errors in measurement of non-uniform sap flow using heat dissipation probes. Tree Physiol. 19, 681-687. doi: 10.1093/treephys/19.10.681

Cueva, E., Acarró, J., 2011. Fénologia des arbres del bosque séco, reserva Laipuna, Ecuador. NCI Loja. Delzon, S. (2015). New insight into leaf drought tolerance. Funct. Ecol. 29, 1247-1249. doi: $10.1111 / 1365-2435.12500$

Eamus, D., and Prior, L. (2001). Ecophysiology of trees of seasonally dry tropics: comparisons among phenologies. Adv. Ecol. Res. 32, 113-197. doi: 10.1016/ S0065-2504(01)32012-3

Ehleringer, J.R., Dawson, T.E., 1992. Water uptake by plants: perspectives from stable isotope composition. Plant Cell Environ. 15, 1073-1082. doi: 10.1111/j.1365-3040.1992.tb01657.x

Elliott, S., Baker, P.J., Borchert, R., 2006. Leaf flushing during the dry season: the paradox of Asian monsoon forests. Glob. Ecol. Biogeogr. 15, 248-257. doi: 10.1111/j.1466-822X.2006.00213.x

FAO, 2001. Global Forest Resources Assessment 2000. Rome: U.N. Food and Agriculture Organization.

Goldstein, G., Andrade, J.L., Meinzer, F.C., Holbrook, N.M., Cavelier, J., Jackson, P., Celis, A., 1998. Stem water storage and diurnal patterns of water use in tropical forest canopy trees. Plant Cell Environ. 21, 397-406. doi: 10.1046/j.1365-3040.1998.00273.x

Goldstein, G., Meinzer, F.C., Bucci, S.J., Scholz, F.G., Franco, A.C., Hoffmann, W., 2008. Water economy of neotropical savanna trees: six paradigms revisited. Tree Physiol. 28, 395-404. doi: 10.1093/treephys/28.3.395

Granier, A., 1987. Evaluation of transpiration in a Douglas-fir stand by means of sap flow measurements. Tree Physiol. 3, 309-320. doi: 10.1093/treephys/3.4.309 
Huang, J., Yu, H., Guan, X., Wang, G., Guo, R., 2016. Accelerated Dryland expansion under climate change. Nat. Clim. Change 6, 166-171. doi: 10.1038/nclimate2837

James, S.A., Meinzer, F.C., Goldstein, G., Woodruff, D., Jones, T., Restom, T., 2003. Axial and radial water transport and internal water storage in tropical forest canopy trees. Oecologia 134, 37-45. doi: 10.1007/s00442-002-1080-8

Kume, T., Takizawa, H., Yoshifuji, N., Tanaka, K., Tantasirin, C., Tanaka, N., Suzuki, M., 2007. Impact of soil drought on sap flow and water status of evergreen trees in a tropical monsoon forest in northern Thailand. For. Ecol. Manage. 238, 220-230. doi: 10.1016/j.foreco.2006.10.019

Kunert, N., Schwendenmann, L., Potvin, C., Hölscher, D., 2012. Tree diversity enhances tree transpiration in a Panamanian forest plantation. J. Appl. Ecol. 49, 135-144. doi: 10.1111/j.13652664.2011.02065.x

McJannet, D., Fitch, P., Disher, M., Wallace, J., 2007. Measurements of transpiration in four tropical rainforest types of north Queensland, Australia. Hydrol. Process. 21, 3549-3564. doi: 10.1002/hyp.6576

Meinzer, F.C., Bond, B.J., Warren, J.M., Woodruff, D.R., 2005. Does water transport scale universally with tree size? Funct. Ecol. 19, 558-565. doi: 10.1111/j.1365-2435.2005.01017.x

Meinzer, F.C., Goldstein, G., Andrade, J.L., 2001. Regulation of water flux through tropical forest canopy trees: Do universal rules apply? Tree Physiol. 21, 19-26.

Meinzer, F.C., Shelley, J., Goldstein, G., 2004. Dynamics of transpiration, sap flow and use of stored water in tropical forest canopy trees. Tree Physiol. 24, 901-909. doi: 10.1093/treephys/24.8.901

Myers, B.A., Duff, G.A., Eamus, D., Fordyce, I.R., O’Grady, A., Williams, R.J., 1997. Seasonal variation in water relations of trees of differing leaf phenology in a wet-dry tropical savanna near Darwin, Northern Australia. Aust. J. Bot. 45, 225-240. doi: 10.1071/BT96015

Nakagawa, S., Schielzeth, H., 2012. A general and simple method for obtaining R2 from generalized linear mixed-effects models. Methods Ecol. Evol. 4, 133-142. doi: 10.1111/j.2041210x.2012.00261.x

Ogburn, R.M., Edwards, E.J., 2010. "The ecological water-use strategies of succulent plants," in Advances in Botanical Research, 1st Edn, Vol. 55, ed. J. A. Callow (New York City, NY: Elsevier Ltd.). doi: 10.1016/B978-0-12-380868-4.00004-1 
Oishi, A.C., Oren, R., Stoy, P.C., 2008. Estimating components of forest evapotranspiration: a footprint approach for scaling sap flux measurements. Agric. For. Meteorol. 148, 1719-1732. doi: 10.1016/j.agrformet.2008.06.013

Pucha-Cofrep, D., Peters, T., Bräuning, A., 2015. Wet season precipitation during the past century reconstructed from tree-rings of a tropical dry forest in Southern Ecuador. Glob. Planet. Change 133, 65-78. doi: 10.1016/j.gloplacha.2015.08.003

R Development Core Team, 2008. R: A Language and Environment for Statistical Computing. Vienna: R Foundation for Statistical Computing. Available at: http://www.R-project.org

Reich, P.B., Borchert, R., 1984. Water stress and tree phenology in a tropical dry forest in the lowlands of Costa Rica. J. Ecol. 72, 61-74. doi: 10.2307/2260006

Reyes-García, C., Andrade, J.L., Simá, J.L., Us-Santamaría, R., Jackson, P.C., 2012. Sapwood to heartwood ratio affects whole-tree water use in dry forest legume and non-legume trees. Trees 26, 1317-1330. doi: 10.1007/s00468-012-0708-5

Schwinning, S., Ehleringer, J.R., 2001. Water use trade-offs and optimal adaptations to pusle driven ecosystems. J. Ecol. 89, 464-480. doi: 10.1046/j.1365-2745.2001.00576.x

Sierra, R., 1999. Propuesta Preliminar de Un Sistema de Clasificación de Vegetación Para El Ecuador Continental. Quito: Proyecto INEFAN/GEF-BIRG Ecociencia. doi: 10.1017/CBO9781107415324.004

Sorensen, L., 2009. A Spatial Analysis Approach to the Global Delineation of Dryland Areas of Relevance to the CBD Programme of Work on Dry and Sub-Humid Lands. Cambridge: UNEP World Conservation Monitoring Centre.

Zanne, A.E., Lopez-Gonzalez, G., Coomes, D.A., Ilic, J., Jansen, S., Lewis, S.L., Miller, R.B., Swenson, N.G., Wiemann, M.C., Chave, J., 2009. Global Wood Density Database. Dryad. Available at: http://hdl.handle.net/10255/dryad.235 


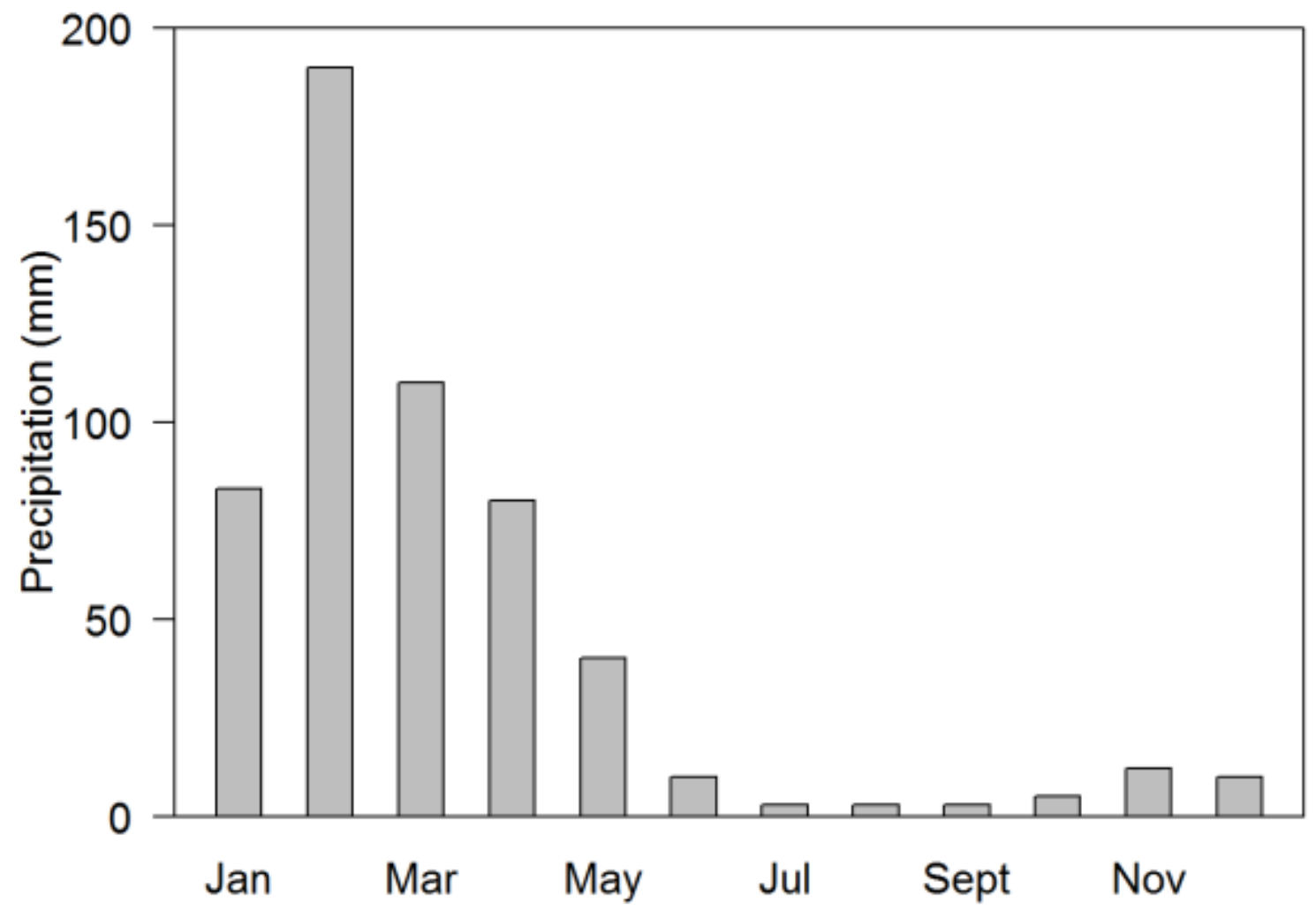

Suppl. Figure 3.1 Monthly rainfall in the study area at $590 \mathrm{~m}$ asl. from 2007-2014. Mean annual precipitation was $540 \mathrm{~mm}$ (Butz et al. 2016). 


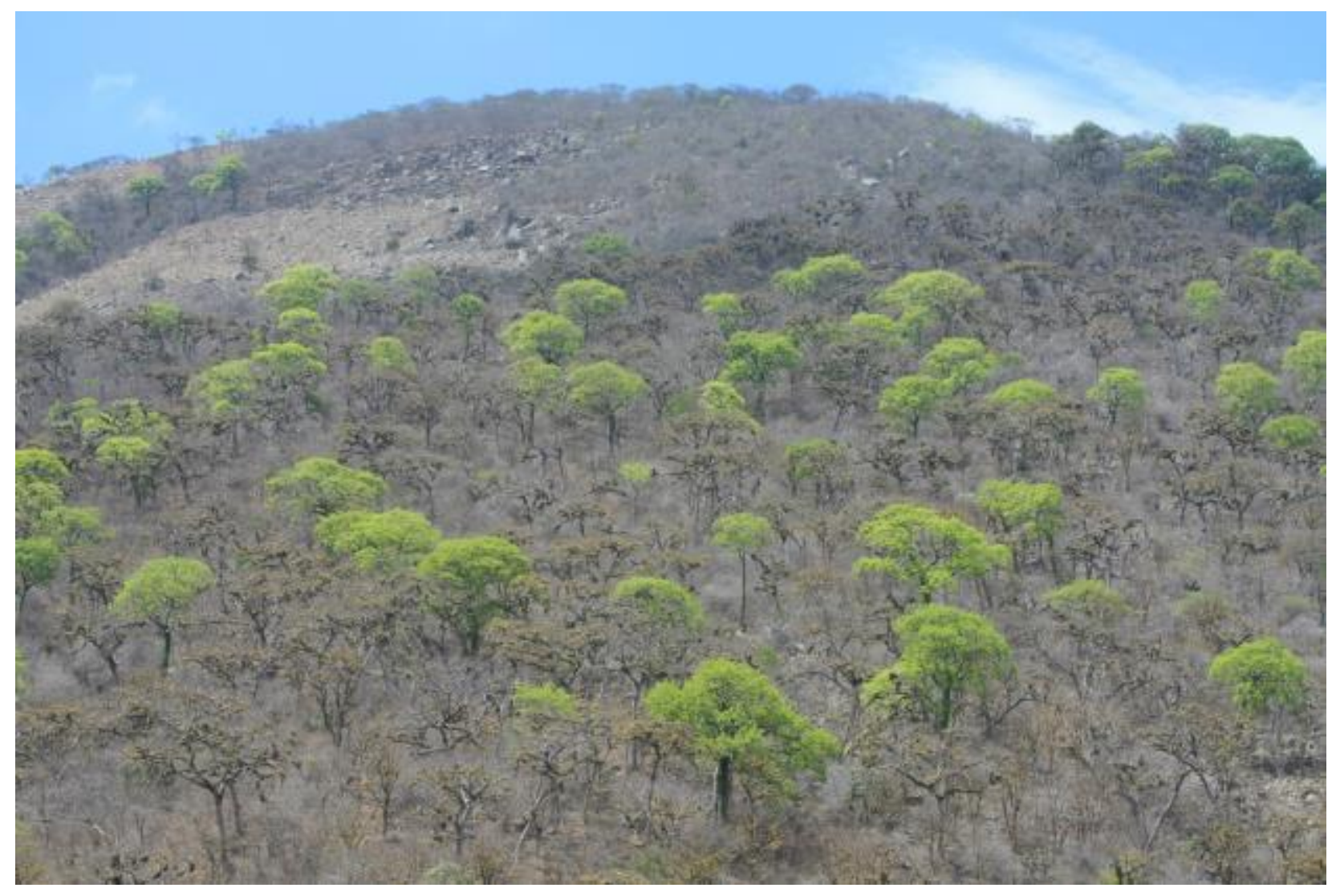

Suppl. Figure 3.2 Ceiba trichistandra at the end of the dry season (December) is already flushing new foliage, while the other deciduous species remain leafless for another month. 


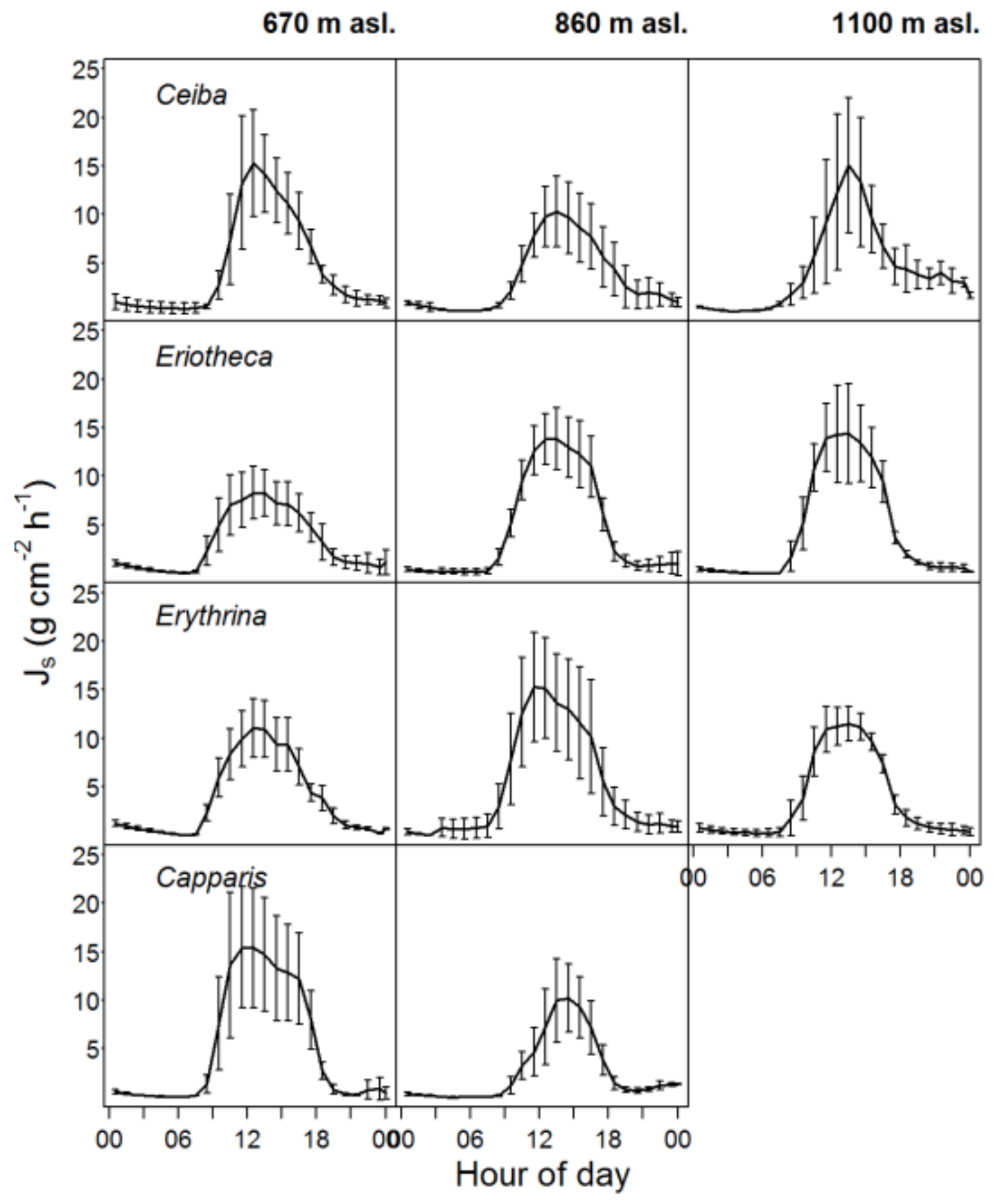

Suppl. Figure 3.3 Characteristic daily sap flux densities (Js) of the four study species on a sunny day with high soil water content during the wet season at three altitudes. Means and standard deviations, $\mathrm{n}=$ 4 trees. 


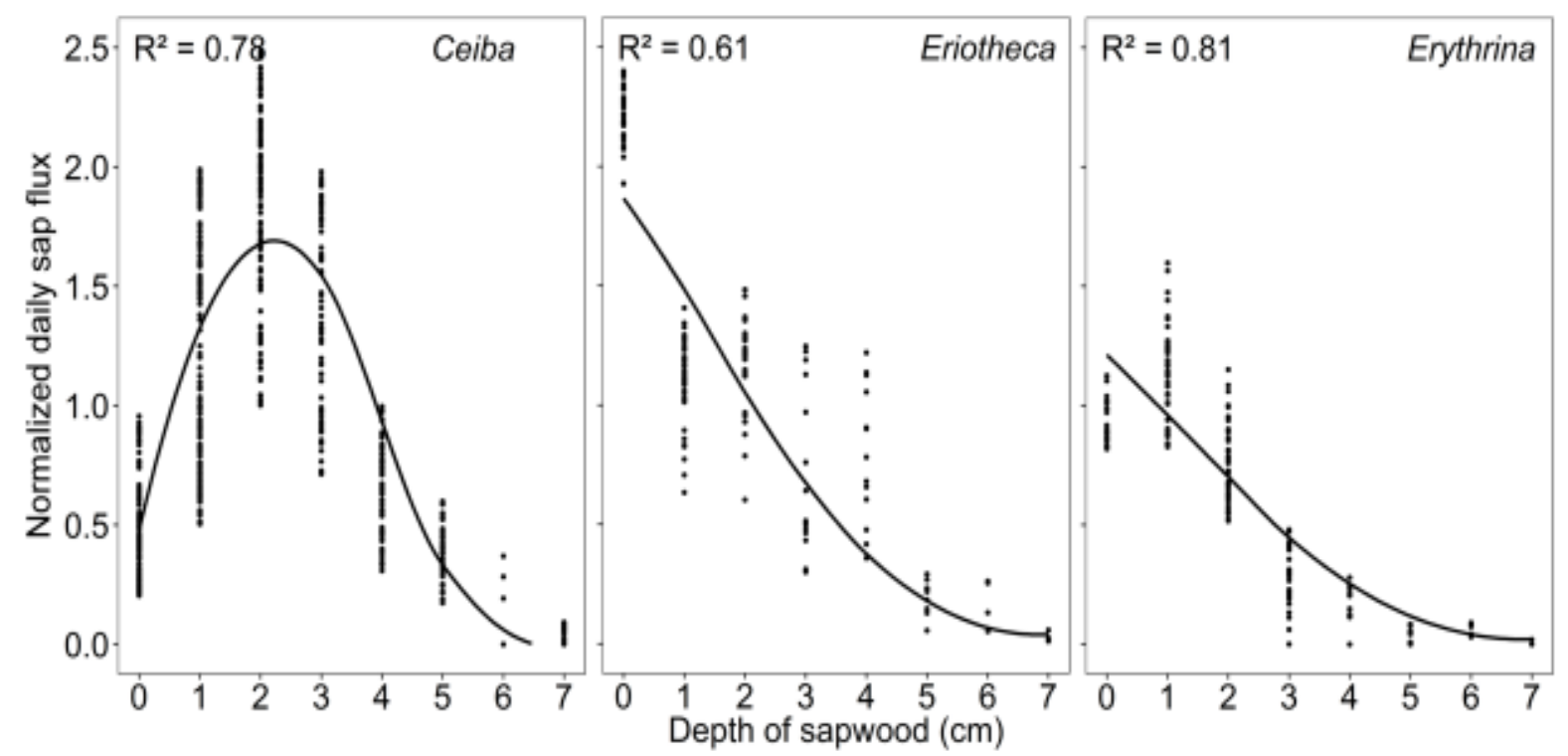

Suppl. Figure 3.4 Radial sap flux profiles for Ceiba, Eriotheca and Erythrina derived by heat field deformation measurements. Sapwood depth starts at the cambium interface. Points indicate mean daily sap flux values per tree, data were fitted to Gaussian equation. 

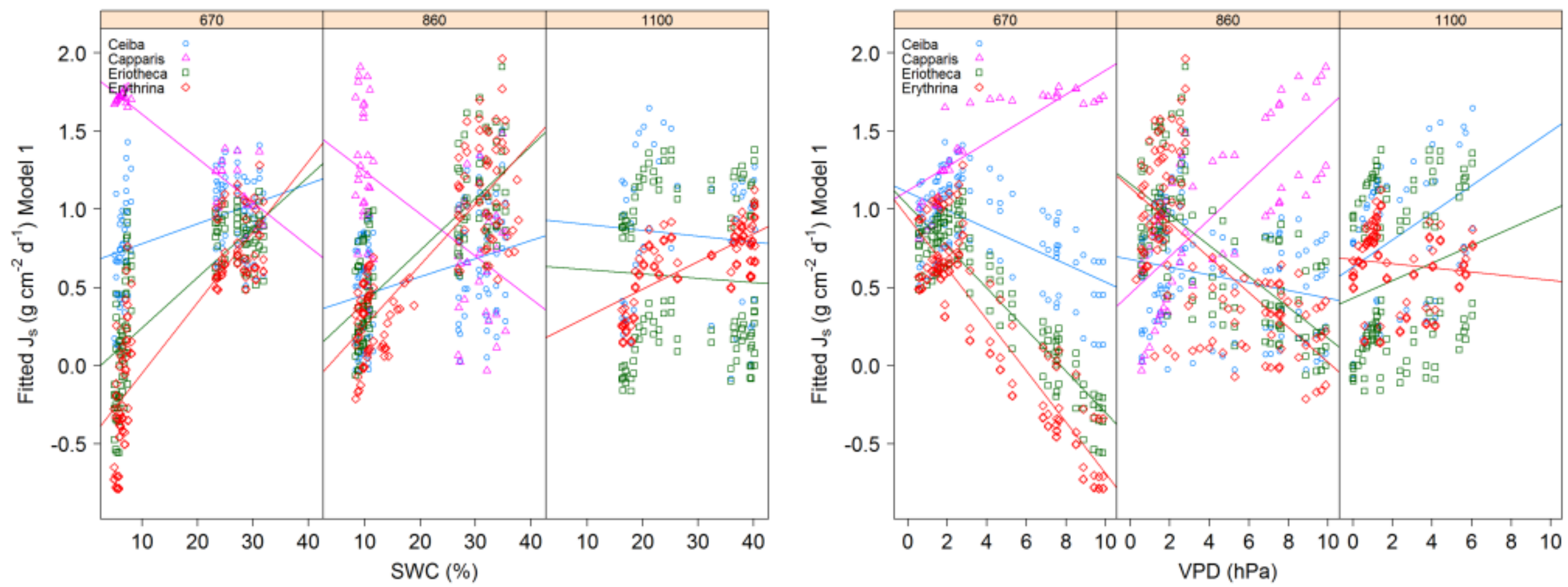

Suppl. Figure 3.5 Fitted responses of sap flux density to SWC and VPD at 670m, 860m and 1100m asl. obtained from Model 1. 


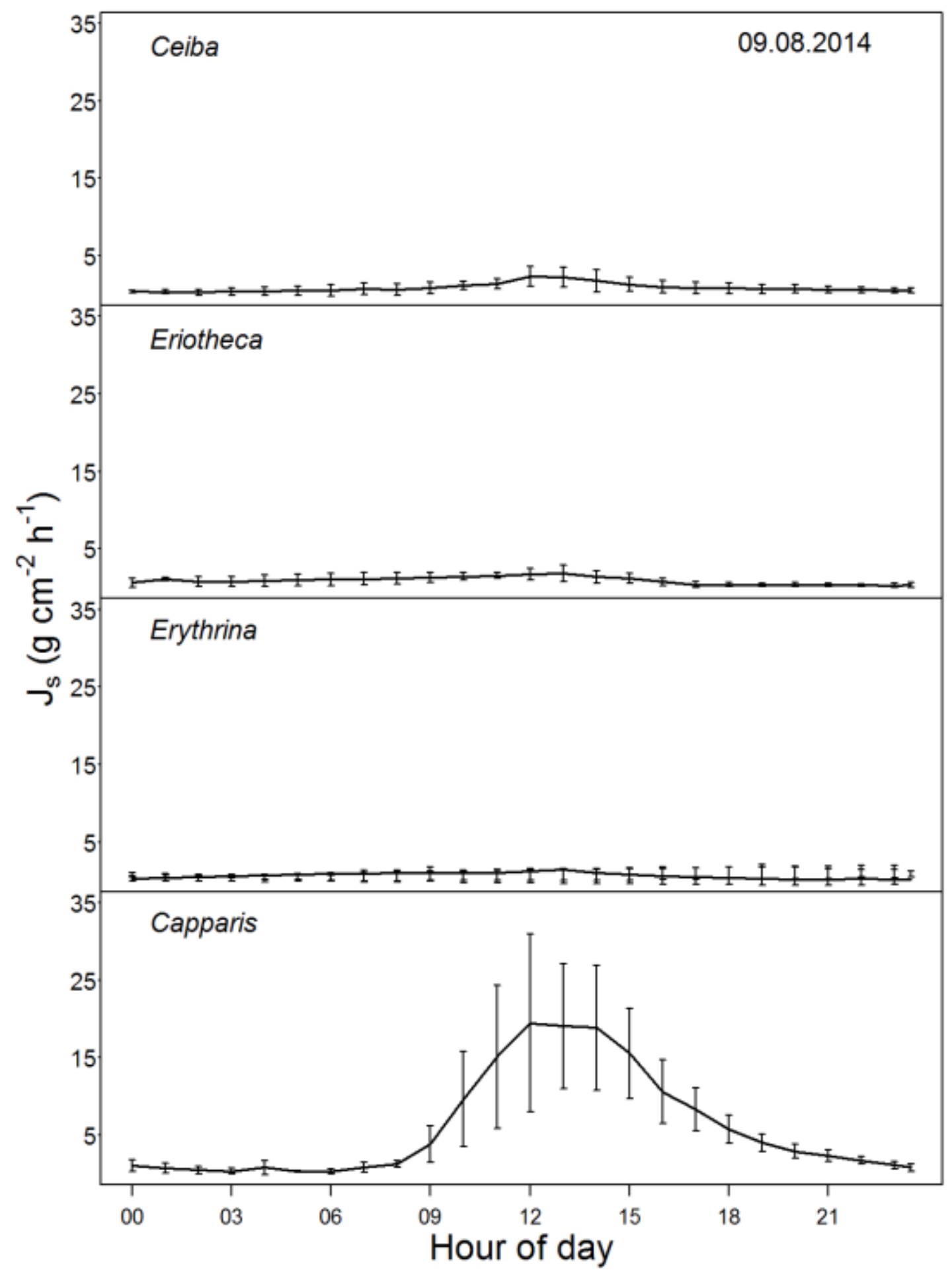

Suppl. Figure 3.6 Characteristic daily sap flux densities (Js) of the four study species on a sunny day with low soil water content $(<15 \%)$ during the dry season at $670 \mathrm{~m}$ asl., deciduous species were defoliated. Means and standard deviations, $n=4$. 


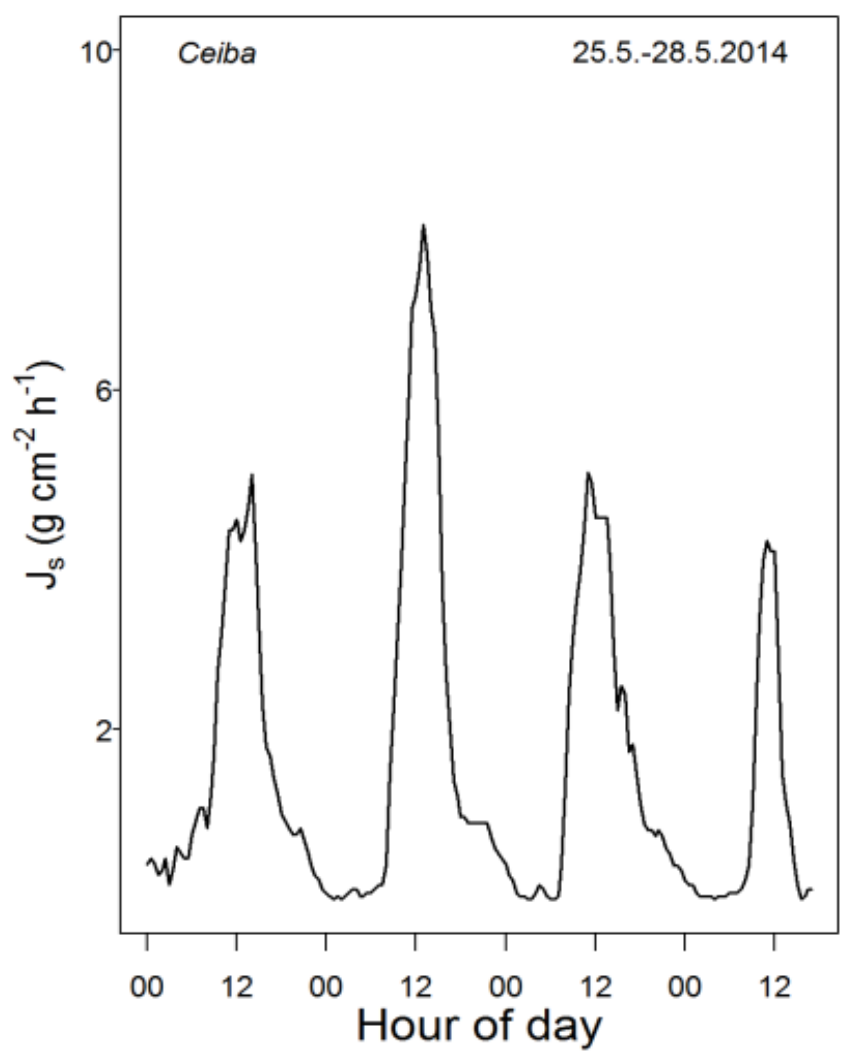

Suppl. Figure 3.7 Characteristic daily sap flux densities (Js) of one Ceiba tree during the dry season 2014, graph shows Ceiba for four days after an intermittent rain fall event during the early dry season after the tree re-flushed its leaves. 


\section{Chapter 4}

\section{Water residence times in trees of a neotropical dry forest}

Sophie Graefe ${ }^{1,2}$, Dongming Fang ${ }^{1,3}$, Philipp Butz ${ }^{1}$

${ }^{1}$ Tropical Silviculture and Forest Ecology, Georg-August-University Göttingen, Germany

${ }^{2}$ State Key Laboratory of Subtropical Silviculture, Zhejiang A\&F University, Lin'an, China

${ }^{3}$ Organic Plant Production and Agroecosystems Research in the Tropics and Subtropics, University of Kassel, Witzenhausen, Germany

${ }^{\dagger}$ Correspondence to: Sophie Graefe, Organic Plant Production and Agroecosystems Research in the Tropics and Subtropics, University of Kassel, Witzenhausen, Germany, E-mail: graefe@ uni-kassel.de

Published in: Trees, Short communication, April 2019

doi:10.1007/s00468-019-01849-y

Chapter version: as published in Trees 


\section{Abstract Chapter 4}

In tropical dry forests, tree species with different drought coping strategies co-exist; leaf deciduous and stem succulent trees are prominent among them. The actual role of stem succulence in tree water use is not fully understood. In a premontane dry forest of southern Ecuador, five tree species were studied in the rainy season including one stem-succulent species (Ceiba trichistandra). All species were studied at the same site and some also across a soil moisture gradient. Deuterium tracing suggests species-specific mean residence times between 11 and 22 days. Mean residence times for Ceiba and two other deciduous tree species were about twice as high as those of two evergreen tree species. Differences in soil moisture did not significantly affect tree water residence times. Our and literature data indicate that across species, residence times increase with tree diameter and decrease with wood density. The stem-succulent Ceiba is characterized by a big stem and a low wood density; the observed residence times in the rainy season were situated on the continuum as derived from a larger data set. The succulent stem may, however, play a special role for leaf flushing at the end of the dry season.

Keywords: Ecuador, Deuterium tracing, Stem succulence, Tree size, Evergreen, Deciduous 


\subsection{Introduction}

Dryland forests cover extended areas, which are significantly larger than previously estimated (Bastin et al., 2017). In tropical dry forests, many tree species are leaf deciduous but also evergreen and brevideciduous (Borchert, 1994; Worbes et al., 2013). Stem water storage allows trees to survive periods of drought (Holbrook, 1995). The ability to withdraw water from sapwood is an important function of trees in the seasonally dry tropics to reduce the risk of vessel embolism and regulate diurnal water deficits (Scholz et al., 2007; Pfautsch and Adams, 2013). Especially during periods of imbalanced relation between water availability and transpiration demand, water storage was proven to be important for xylem safety of trees (Goldstein et al., 1998; Meinzer et al., 2006; Čermák et al., 2007; Meinzer et al., 2010; Carrasco et al., 2014).

Stem succulents are prominent among deciduous species in tropical dry forests, and their stem water storage has been mainly linked with water demands for reproduction and leaf flushing at the end of the dry season (Reich and Borchert, 1984; Borchert, 1994). This was also shown for the stem-succulent, deciduous baobab trees (Adansonia spp.) of Madagascar; in this species, stem-stored water was further important for conduit safety and turgor maintenance during the wet season, but apparently was not used for maximizing stomatal opening (Chapotin et al., 2006a, b).

Water residence time can be estimated by deuterium (D2O) tracing (Calder et al., 1986; James et al., 2003; Meinzer et al., 2006). When water is only used for day-to-day transpiration, the residence time of a tracer is assumed to be rather short (a couple of days), whereas in trees accessing internal water reserves for transpiration, tracer residence time will be longer (several weeks). Radial transport of D2O could be detected in several tree species of the seasonally dry tropics, which points to an exchange of water between stem storage compartments and the transpiration stream (James et al., 2003). In their study, tracer residence time was positively correlated with diurnal water storage capacity (James et al., 2003). Actual residence time may, however, vary according to season and also to environmental conditions, including soil moisture availability.

The aim of the present study was to analyze water residence time in trees of a premontane dry forest in southern Ecuador by means of deuterium tracing. In this forest, tree species with different drought coping strategies co-occur, which are expected to differ in water residence time. In this context, we studied two evergreen non-succulent species, two deciduous non-succulent species and the deciduous, stem-succulent Ceiba trichistandra. We assumed that water residence time in Ceiba will be larger than in the other species. 


\subsection{Material and methods}

\subsubsection{Study site}

The study was conducted in the protected forest reserve Laipuna $\left(4^{\circ} 22^{\prime} \mathrm{S}, 79^{\circ} 90^{\prime} \mathrm{W}\right)$, which is located in the Ecuadorian province of Loja and part of the Tumbesian dry forest ecoregion of northern Peru and southern Ecuador. The forest receives low annual rainfall with an average of $540 \mathrm{~mm} \mathrm{year}^{-1}$ at $670 \mathrm{~m}$ asl (Butz et al., 2017) and is characterized by a dry season of 8 months (May-December).

During the rainy season, monthly rainfall varies between 50 and $200 \mathrm{~mm}$, with February generally being the wettest months. Average temperature is $23.7^{\circ} \mathrm{C}$ with little variation throughout the year. The Laipuna reserve has a size of 1680 ha and stretches over altitudes of 600-1400 m asl. Precipitation input increases from low to high altitude (Spannl et al., 2016), resulting in a soil moisture gradient. The forest does not receive any silvicultural treatment. A total of 39 tree species were recorded in the forest, of which eight were evergreen species (Homeier, unpublished). The majority of trees has a droughtdeciduous leaf phenology and shed leaves with the onset of the dry season in May.

\subsubsection{Tracer study}

We studied 35 trees out of five tree species (Table 1). Two species are evergreen (Capparis scabrida and Geoffroea spinosa), two are deciduous non-stem-succulent species (Eriotheca ruizii and Erythrina velutina) and one species is deciduous stem succulent (Ceiba trichistandra). The diameter of the studied trees ranged from 20 to $76 \mathrm{~cm}$ and tree height from 7 to $15 \mathrm{~m}$ (Table 4.1).

The evergreen Capparis had lowest and the deciduous stem-succulent (Ceiba) highest dimensions (Table 4.1). In the deciduous species, the study includes three trees per species at three altitudes (670 $\mathrm{m}, 860 \mathrm{~m}$ and $1100 \mathrm{~m}$ asl.). Mean soil water content ranged from $20 \%$ at the lowest altitude to $35 \%$ at the highest altitude (Suppl. Table 4.1). Tracer was applied in March 2015 (mid-wet season) with 0.16 $\mathrm{ml} \mathrm{D}_{2} \mathrm{O}$ per $\mathrm{cm}$ circumference. This was about two-third less than recommended by Meinzer et al., (2003), but was a result of tracer shortage. The two evergreen species were only sampled at $670 \mathrm{~m}$ asl. (the lowest altitude), since they were not present in sufficient numbers at $860 \mathrm{~m}$ asl and completely absent at $1100 \mathrm{~m}$ asl. Tracer was applied in May 2015 (end of wet season) with $0.5 \mathrm{ml} \mathrm{D} 2 \mathrm{O}$ per cm circumference according to Meinzer et al., (2003). Mean soil water content was $10 \%$, as opposed to $20 \%$ at the same altitude when the deciduous species were studied. Other climatic parameters (temperature, relative humidity (RH), vapor pressure deficit (VPD)) differed only slightly between the two experiments (Suppl. Table 4.1). 
Table 4.1 Characteristics of tree species studied (mean with SD in brackets), wood density taken from Chave et al. (2009) and Zanne et al. 2009.

\begin{tabular}{lllcccccc}
\hline Species & Family & Phenology & $\begin{array}{c}\mathrm{N} \\
\text { (trees })\end{array}$ & $\begin{array}{c}\text { DBH } \\
(\mathrm{cm})\end{array}$ & $\begin{array}{c}\text { Range of } \\
\text { DBH }(\mathrm{cm})\end{array}$ & $\begin{array}{c}\text { Height } \\
(\mathrm{m})\end{array}$ & $\begin{array}{c}\text { Wood density } \\
\left(\mathrm{g} \mathrm{cm}^{-3}\right)\end{array}$ & $\begin{array}{c}\mathrm{J}_{\mathrm{s}} \\
\left(\mathrm{g} \mathrm{cm}^{-2} \mathrm{~d}^{-1}\right)\end{array}$ \\
\hline Capparis scabrida & Capparaceae & Evergreen & 4 & $19.7(5.4)$ & $14.3-25.5$ & $7.4(1.5)$ & 0.69 & $83.5(33.2)$ \\
Geoffroea spinosa & Fabaceae & Evergreen & 3 & $27.7(5.9)$ & $21.0-32.1$ & $7.9(0.8)$ & 0.75 & - \\
Erythrina velutina & Fabaceae & Brevi-deciduous & 9 & $27.9(9.3)$ & $14.4-40.0$ & $10.1(3.6)$ & 0.2 & $56.9(15.4)$ \\
Eriotheca ruizii & Malvaceae & Deciduous & 10 & $56.4(17.3)$ & $37.6-91.6$ & $13.1(3.3)$ & 0.47 & $63.8(23.1)$ \\
Ceiba trichistandra & Malvaceae & Deciduous, stem succulent & 9 & $76.1(14.7)$ & $61.6-94.4$ & $15.0(3.9)$ & 0.26 & $59.1(22.4)$ \\
\hline
\end{tabular}


We adopted the procedure for tracer injection from James et al., (2003). Deuterium oxide $\left(\mathrm{D}_{2} \mathrm{O}, 99\right.$ atom\% D, Sigma-Aldrich, Germany) was injected into the stems approximately $30 \mathrm{~cm}$ above ground through holes that were drilled at a distance of $5 \mathrm{~cm}$ around the trunk at a downward pointing angle of $30^{\circ}$. The holes had a depth of $7 \mathrm{~cm}$ and a diameter of $5 \mathrm{~mm}$. The undiluted tracer was injected immediately after drilling between 8 and 11 a.m.; identical volumes were applied to each hole, which were subsequently sealed with wood putty.

After tracer injection, five leaves from the upper crown were collected at noon at daily intervals for the first 7 days and later on every 3 days until day 21 after tracer injection. Reference samples were taken at day 0 before tracer application. The leaves were sealed in plastic bags and exposed to sunlight for 30 min (Meinzer et al., 2003). During this step, possible isotopic fractionation might have taken place. Condensed water was collected with a pipette, transferred into Eppendorf tubes and stored at $4{ }^{\circ} \mathrm{C}$ until analysis. The isotope signature was determined with a high-temperature element analyzer (TC/EA) coupled to an isotope ratio mass spectrometer (Delta V Plus, Thermo-Electron Cooperation, Bremen, Germany) at the Center for Stable Isotope Research and Analysis (KOSI) at the University of Göttingen. The measurement precision was $2 \%$.

\subsubsection{Soil moisture, micrometeorological and tree structural measurement}

Volumetric soil water content (SWC, \%) was continuously measured at the three altitudes with water content reflectometers (CS616, Campbell Scientific Inc., Logan, UT, USA). Four probes were installed in a square of $4 \mathrm{~m} \times 4 \mathrm{~m}$ vertically at a depth of $0-30 \mathrm{~cm}$. Air temperature $\left({ }^{\circ} \mathrm{C}\right)$ and relative humidity (\%) were measured at open conditions near the study site (CS215, Campbell Scientific Inc., Logan, UT, USA) and used to calculate vapor pressure deficit of the air (VPD, hPa). For every tree, we measured diameter at breast height (DBH) with a diameter tape, and tree height with a Vertex II height measurement device (Haglöfs, Sweden).

\subsubsection{Data analysis and statistics}

Water transport characteristics derived from $\mathrm{D}_{2} \mathrm{O}$ tracing were calculated based on James et al. (2003), Meinzer et al. (2006) and Schwendenmann et al. (2010). Tracer arrival (T-arrival, days) was defined as the time span that passed until the first sample exceeded $10 \%$ of maximum deuterium concentration. T$\max$ (days) refers to the point in time after tracer injection when maximum deuterium concentration was observed. Velocity of $\mathrm{D}_{2} \mathrm{O}$ transport $\left(\mathrm{V}-\mathrm{D}_{2} \mathrm{O}, \mathrm{m}^{-1 a y}{ }^{-1}\right)$ was estimated as tree height divided by number of days required to detect $\mathrm{D}_{2} \mathrm{O}$ tracer in transpired water. Tracer residence time (T-residence, days) was estimated as the period when $\mathrm{D}_{2} \mathrm{O}$ concentration in leaves dropped below $10 \%$ of the maximum $\mathrm{D}_{2} \mathrm{O}$ concentration. When T-residence exceeded 21 days (the lengths of the experiment), it was estimated by extrapolating deuterium concentration of the last 3 days to the $10 \%$ line (Meinzer et al., 2006). 
Mean daily water use estimates obtained with $\mathrm{D}_{2} \mathrm{O}$ tracing $\left(\mathrm{WU}-\mathrm{D}_{2} \mathrm{O}, \mathrm{kg} \mathrm{day}^{-1}\right.$ ) are derived according to Calder (1991) as follows:

$$
W U_{D_{2} O}=\frac{M}{\sum_{i=1}^{T} C_{i} \Delta \mathrm{t}_{i}},
$$

where $\mathrm{M}$ is the total mass injected, $\mathrm{C}_{\mathrm{i}}$ is the mass concentration $\left(\mathrm{g} \mathrm{kg}^{-1}\right)$ in the time increment of $\mathrm{D}_{2} \mathrm{O}$ in the leaf water sample, which was converted from the notation of $\mathrm{D}_{2} \mathrm{O}(\delta \mathrm{D}, \%)$ values, $\Delta \mathrm{t}_{\mathrm{i}}$ is the duration of the time increment (days) and $\mathrm{T}$ is the total number of days of the experiment (=21 days).

Linear and logarithmic regressions were used to explore relationships of tree structural parameters (DBH, height, stem volume, wood density) with water transport characteristics. Analysis of variance (ANOVA) was performed for key parameters derived from the D2O tracing experiment ( $\mathrm{T}$-arrival, $\mathrm{T}$ max, T-residence, $V-\mathrm{D}_{2} \mathrm{O}, \mathrm{WU}-\mathrm{D}_{2} \mathrm{O}$ ) within and across tree types (deciduous and evergreen). All data analyses were performed with SAS 9.4 (SAS Institute Inc., Cary, NC, USA).

\subsection{Results and discussion}

Overall, the two evergreen species showed clearer tracer trajectories, higher peaks and less variability compared to the three deciduous species (Figure 4.1). These patterns may originate from the higher amount of tracer the evergreens received; however, the tracer volumes per tree dimensions were well in all trees in the range of other studies (Suppl. Table 4.2), which did not indicate biases due to tracer volume applied. The observed differences may be also attributed to environmental conditions, but except for soil moisture microclimate differed only marginally between the two sampling dates (Suppl. Table 4.1). Still it is also very likely that the differences among species we observed are related to leaf phenology and tree structure. 


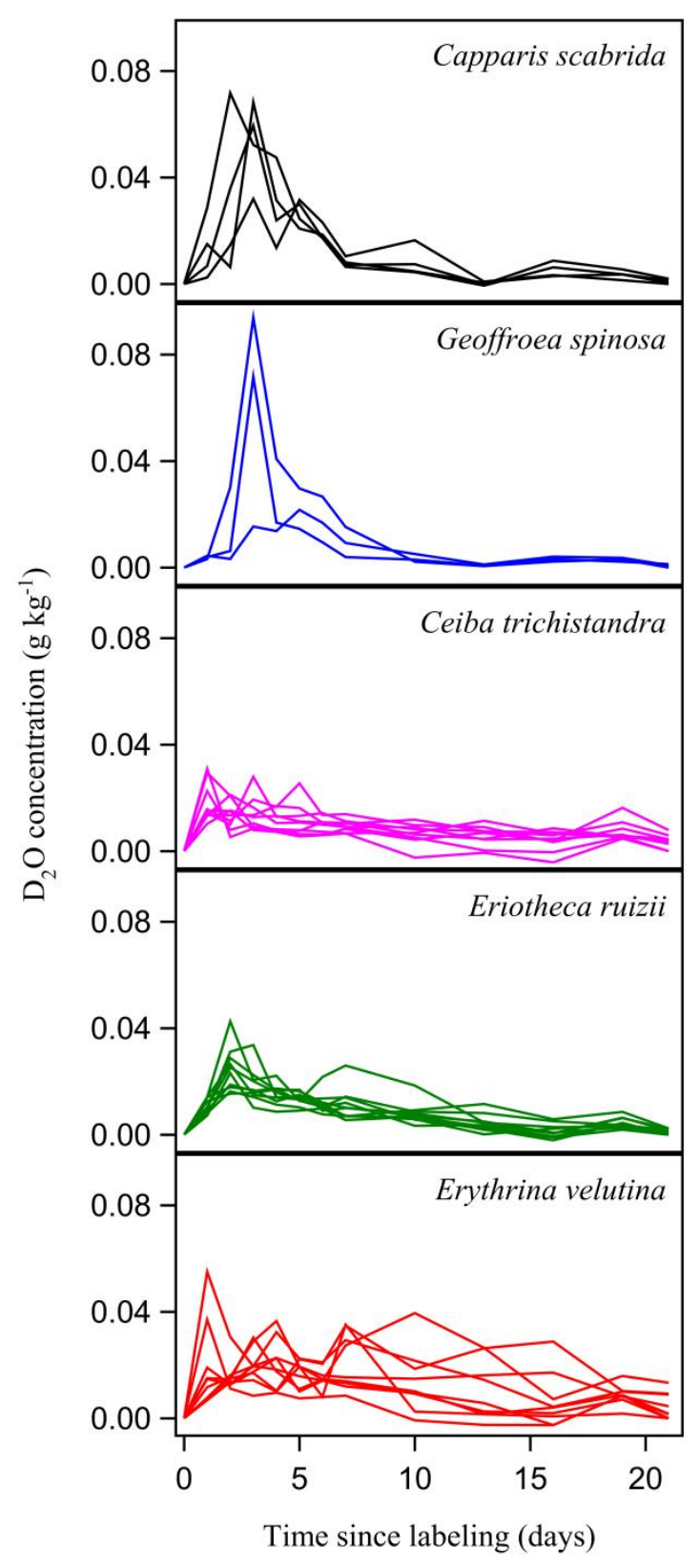

Figure 4.1 Deuterium concentration in transpired water over the duration of the experiment. The deciduous species were sampled at three different altitudes $(670 \mathrm{~m}, 860 \mathrm{~m}, 1100 \mathrm{~m}$ asl.).

We followed the assumptions of Calder (1991) and Calder et al. (1992) that a complete mixing of tracer occurs in the stem and all tracer is passing through the tree. However, we can expect a certain degree of error due to radial water transport (Kalma et al., 1998; James et al., 2003). Kalma et al. (1998) provided evidence for a $10 \%$ error in sap flow due to the retention of tracer in the heartwood. Standardizing the amount of applied tracer based on stem circumference instead of sap wood area may also lead to different tracer concentrations in species that differ in sap wood area, which could explain differences in tracer peaks and residence times observed in the present study. 
In the three deciduous species (Ceiba, Eriotheca and Erythrina), the tracer was already detected 1 day after injection, whereas the two evergreen species (Capparis and Geoffroea) showed a slightly delayed tracer arrival. Maximum tracer values in transpired water were recorded after 2.3-4.4 days (Table 4.2). Tracer velocities were found in the range of 5.6-15.0 $\mathrm{m} \mathrm{day}^{-1}$ and were significantly lower in the two evergreen species compared to the three deciduous species, with lowest values for Geoffroea and highest for Ceiba (Table 4.2, Figure 4.2a). Tracer velocity as an estimate of maximum sap velocity depends on xylem hydraulic properties (James et al., 2003). Meinzer et al. (2006) found a positive linear relationship between tracer velocity and total daily sap flux in the outer sapwood of conifers. This relationship, however, could not be established in the present study (Table 4.1). Highest water use estimates from $\mathrm{D}_{2} \mathrm{O}$ tracing were obtained for Geoffroea and Ceiba with 246 and $208 \mathrm{~kg} \mathrm{day}^{-1}$, respectively. Lowest water use estimates were calculated for the brevideciduous Erythrina $\left(70.3 \mathrm{~kg} \mathrm{day}^{-1}\right.$; Table 4.2, Figure 4.2b).

Table 4.2 Key results from the deuterium tracing experiment (mean with SD in brackets). Data of the deciduous species was derived from three different altitudes. $\mathrm{T}=$ time, $\mathrm{V}=$ velocity, $\mathrm{WU}=$ water use. Different lowercase letters indicate significant differences between species; different capital letters indicate significant difference between tree phenologies at $\mathrm{p}<0.05$.

\begin{tabular}{lcccccc}
\hline Species & $\begin{array}{c}\mathrm{N} \\
\text { (trees) }\end{array}$ & $\begin{array}{c}\mathrm{T} \text {-arrival } \\
(\text { days })\end{array}$ & $\begin{array}{c}\mathrm{T} \text {-max } \\
(\text { days })\end{array}$ & $\begin{array}{c}\mathrm{T} \text { - residence } \\
(\text { days })\end{array}$ & $\begin{array}{c}\mathrm{V}-\mathrm{D}_{2} \mathrm{O} \\
\left(\mathrm{m} \mathrm{day}^{-1}\right)\end{array}$ & $\begin{array}{c}\mathrm{WU}^{2} \mathrm{D}_{2} \mathrm{O} \\
\left(\text { kg day }^{-1}\right)\end{array}$ \\
\hline Capparis scabrida & 4 & $1.3(0.5)^{\mathrm{a}}$ & $2.8(0.5)^{\mathrm{a}}$ & $14.3(4.2)^{\mathrm{a}}$ & $6.3(1.6)^{\mathrm{ab}}$ & $136.2(56.7)^{\mathrm{a}}$ \\
Geoffroea spinosa & 3 & $1.8(1.0)^{\mathrm{b}}$ & $3.5(1.0)^{\mathrm{a}}$ & $10.8(6.3)^{\mathrm{a}}$ & $5.6(2.7)^{\mathrm{b}}$ & $246.0(89.2)^{\mathrm{b}}$ \\
Erythrina velutina & 9 & $1.0(0)^{\mathrm{a}}$ & $4.4(3.0)^{\mathrm{a}}$ & $19.2(3.9)^{\mathrm{b}}$ & $10.1(3.6)^{\mathrm{ac}}$ & $70.3(46.0)^{\mathrm{a}}$ \\
Eriotheca ruizii & 10 & $1.0(0)^{\mathrm{a}}$ & $2.3(0.7)^{\mathrm{a}}$ & $18.8(2.4)^{\mathrm{b}}$ & $13.1(3.3)^{\mathrm{cd}}$ & $173.6(47.4)^{\mathrm{ab}}$ \\
Ceiba trichistandra & 9 & $1.0(0)^{\mathrm{a}}$ & $2.9(2.0)^{\mathrm{a}}$ & $21.7(1.7)^{\mathrm{b}}$ & $15.0(3.9)^{\mathrm{d}}$ & $207.9(71.6)^{\mathrm{b}}$ \\
\hline Evergreen & 7 & $\begin{array}{c}1.6 \\
(0.5)^{\mathrm{A}}\end{array}$ & $3.2(0.6)^{\mathrm{A}}$ & $12.8(2.1)^{\mathrm{A}}$ & $5.6(1.0)^{\mathrm{A}}$ & $191.1(77.6)^{\mathrm{A}}$ \\
Deciduous & 28 & $1.0(0)^{\mathrm{A}}$ & $3.2(1.1)^{\mathrm{A}}$ & $19.9(1.5)^{\mathrm{B}}$ & $12.7(2.5)^{\mathrm{B}}$ & $150.6(71.6)^{\mathrm{A}}$ \\
\hline
\end{tabular}



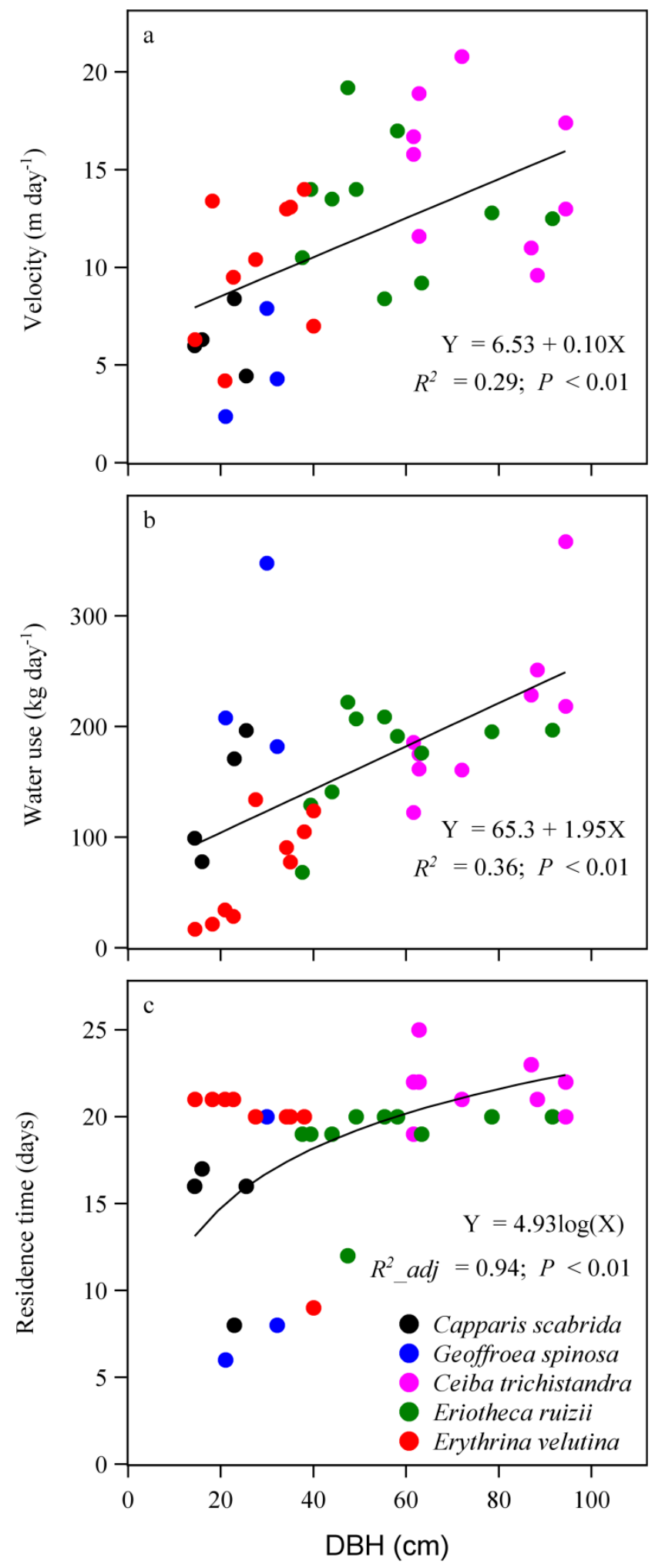

Figure 4.2 (a) Tracer velocity (m day-1), (b) water use (kg day-1), and (c) tracer residence time (days) in relation to tree $\mathrm{DBH}(\mathrm{N}=35)$

Tracer residence time can be regarded as an indicator of diurnal water exchange capacity (James et al., 2003) and was found to be highly variable in previous studies (Suppl. Table 4.3). The present study yielded tracer residence times between 11 and 14 days for the two evergreen species (Capparis and 
Geoffroea) and 19-22 days for the three deciduous species (Ceiba, Eriotheca and Erythrina). James et al. (2003) found a larger range of tracer residence times (between 2 and 22 days) in a seasonally dry forest in Panama, whereby shortest residence time was reported for the deciduous species Cordia alliodora. In trees of a 12-year-old reforestation stand in the Philippines, tracer residence times of 4.312.5 days were recorded (Schwendenmann et al., 2010). Longest tracer residence times were observed by Meinzer et al. (2006) on conifers in a temperate climate, which ranged between 36 and 79 days. Generally, tracer residence time increased with tree diameter as shown by a synthesis of several studies (Figure 4.3a), and relative water storage capacity was found to be highest in large trees (James et al., 2003; Meinzer et al., 2004). A similar trend was also revealed in the present study, with a positive relationship between residence time and tree diameter, with the longest residence time in the stemsucculent Ceiba (Figure 4.2c, Figure 4.3a). Residence time also increased with tree height and stem volume; in the case of stem volume, however, the relationship did not yield in a robust regression (Suppl. Figure 4.1). Although soil water content differed considerably between the lowest and highest study site, no significant difference in residence time could be observed in the deciduous species that were studied across altitudes (Suppl. Table 4.4).
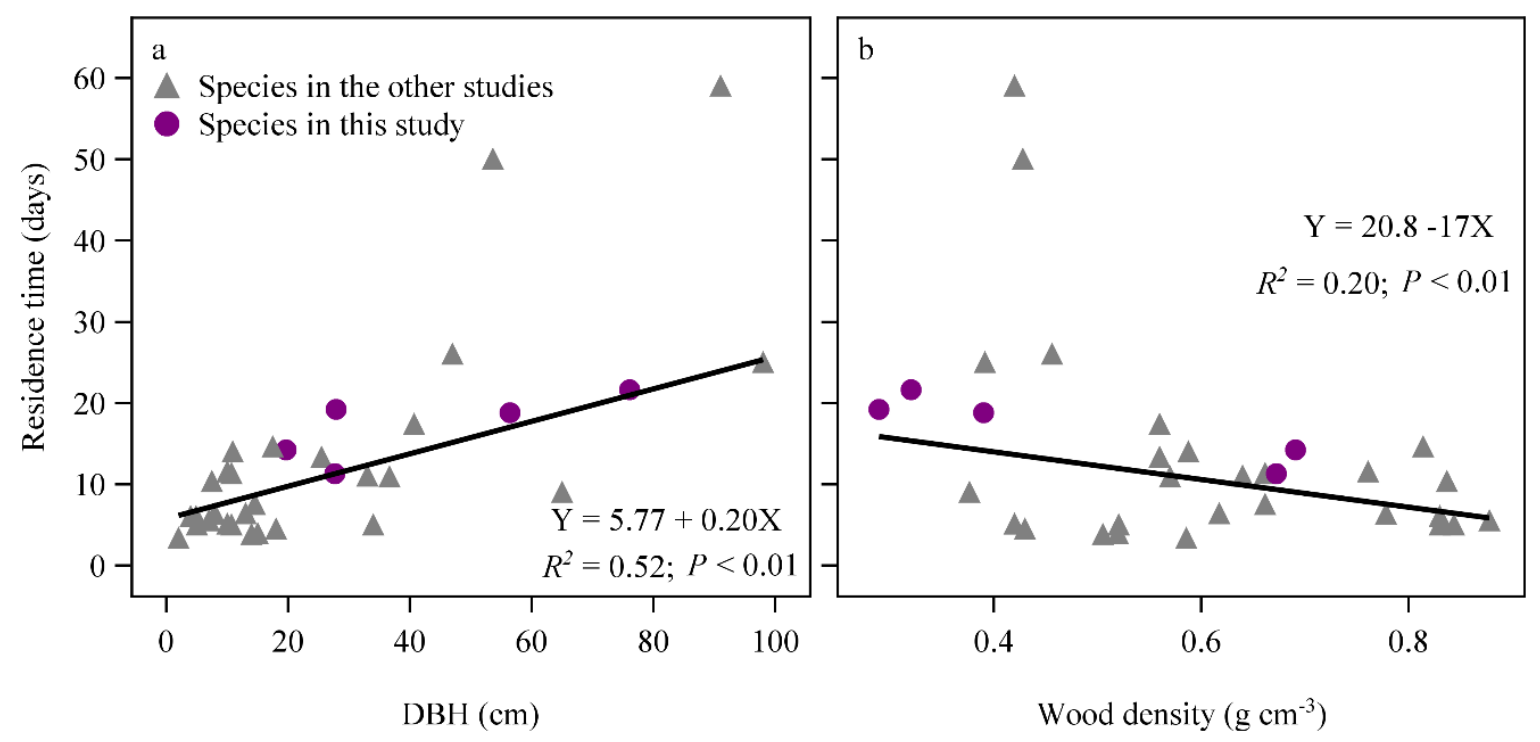

Figure 4.3 Plant water residence time (days) estimated from deuterium tracing in relation to (a) tree DBH and (b) wood density in this study $(n=5)$ and from other studies $(n=25)$. The two outliers with residence time $>40$ days were removed from the regression analysis. See Table S2 in the appendix for a full list of cited studies and species. Wood density taken from Chave et al. (2009) and Zanne et al. (2009).

In contrast to large diameter trees, a study conducted on tropical bamboos found tracer residence times in the range of 5.5-6.3 days only, with no clear relationship between culm water storage and bamboo diameter (Fang, 2017). The relative shorter residence time on bamboos was attributed to the small volume of the hollow culms, which constrains water storage ability that was estimated to contribute only $10 \%$ to daily transpiration. These findings on bamboos reversely imply that the longer residence time of 
species in the present study might indicate larger water storage ability, which further explains their survival strategy in this ecosystem with extended dry periods.

Smaller trees have a faster internal water circulation to support the transpiration demand on a daily basis. Large trees in contrast store more water to buffer long-term seasonal drought to compensate for hydraulic limitations to water transport and to flush new leaves (Borchert, 1994; Phillips et al., 2003; Butz et al., 2018). The coordination among hydraulic traits of different plant tissues might play a vital role for stem water storage processes, such as in the case of Adansonia spp. from Madagascar, which are characterized by low wood density, high vessel size, low capacitance and a resulting high vulnerability to xylem embolism (Chapotin et al., 2006b). Appearance and traits of Ceiba from our study are very similar to the aforementioned species.

Wood anatomy is a major determinant of drought adaptation and influences the rate of water uptake during rehydration (Borchert and Pockman, 2005). Overall, tracer residence time significantly and negatively correlated with wood density, as shown for species from the present study and those from the literature survey (Figure 4.3b). Wood-saturated water content was found to be inversely related to wood density, and a species-independent scaling of sapwood capacitance with wood density could be established (Stratton et al., 2000; Scholz et al., 2007). Species with higher wood-saturated water content are expected to be more efficient with long distance water transport and have higher maximum photosynthetic rates. It further allows stem-succulent species to produce new leaves when growing conditions are still unfavorable (Stratton et al., 2000). In a previous study, Ceiba reacted most sensitive to fluctuating moisture availability with radial stem variations among the studies species. The deciduous Erythrina in contrast did not show a pronounced diurnal shrinking and swelling (Butz et al., 2017). In the present study, however, both species did not differ noticeable in tracer residence time. This indicates low internal water reserves in Erythrina; even so wood density of this species is $0.2 \mathrm{~g} \mathrm{~cm}^{-3}$ that is considerably low, despite being a legume tree, which is often characterized by rather high wood densities (Chave et al., 2009; Zanne et al., 2009; Powers and Tiffin, 2010). Also Erythrina showed a fast reflushing of leaves when environmental conditions became favorable (Butz et al., 2017). For the evergreen species in contrast, it seems to be advantageous to have a rather short stature and high wood density (e.g., $0.75 \mathrm{~g} \mathrm{~cm}^{-3}$ for Geoffroea and $0.69 \mathrm{~g} \mathrm{~cm}^{-3}$ for Capparis; Chave et al., 2009; Zanne et al., 2009), enabling a better adaptation to resist drought-induced embolism and efficient water transport under high demand (Hacke et al., 2001).

The results of the present study suggest that tree size and wood density are the most important factors among the observed parameters influencing residence time in the studied tree species during the rainy season, including stem-succulent Ceiba. Differences in soil moisture did not affect residence times in the deciduous species that were studied at different altitudes. Residence times in the evergreen species were lower than in the deciduous species. The question whether water residence time is influenced by 
season, e.g., under water limiting conditions with the onset of the dry season when trees start shedding leaves, however, requires further study.

\section{Acknowledgements}

The grant of the German Science Foundation (DFG) through PAK823-825 "Platform for Biodiversity and Ecosystem Monitoring and Research in South Ecuador" (GR 4293/2-1, HO 2119/7-1) is gratefully acknowledged. We thank the Ecuadorian Ministry of the Environment (MAE) for the research permission and Nature and Culture International (NCI) for logistic support. We acknowledge valuable discussions with Dirk Hölscher on the manuscript. We also thank Patricio Crespo from the University of Cuenca for providing laboratory space and conducting initial stable isotope analyses. 


\subsection{References Chapter 4}

Bastin, J.F., Berrahmouni, N., Grainger, A., Maniatis, D., Mollicone, D., Moore, R., Patriarca, C., Picard, N., Sparrow, B., Abraham, E.M., Aloui, K., Atesoglu, A., Attore, F., Bassüllü, Ç., Bey, A., Garzuglia, M., García-Montero, L.G., Groot, N., Guerin, G., Laestadius, L., Lowe, A.J., Mamane, B., Marchi, G., Patterson, P., Rezende, M., Ricci, S., Salcedo, I., Sanchez-Paus Diaz, A., Stolle, F., Surappaeva, V., Castro, R., 2017. The Extent of Forest in Dryland Biomes. Science 356. https ://635-638. 10.1126/science.aam6527

Borchert, R., 1994. Soil and stem water storage determine phenology and distribution of tropical dry forest trees. Ecology 75:1437-1449. https ://doi.org/10.2307/19374 67

Borchert, R., Pockman, W.T., 2005. Water storage capacitance and xylem tension in isolated branches of temperate and tropical trees. Tree Physiol 25:457-466. https ://doi.org/10.1093/treephys/25.4.457

Butz, P., Raffelsbauer, V., Graefe, S., Peters, T., Cueva, E., Hölscher, D., Bräuning, A., 2017. Tree growth and water use as climatic indicators in a tropical dry forest ecosystem. Ecol Indic 83:559-571. https ://doi.org/10.1016/j.ecoli nd.2016.11.021

Butz, P., Hölscher, D., Cueva, E., Graefe, S., 2018. Tree water use patterns as influenced by phenology in a dry forest of southern Ecuador. Front Plant Sci 9:945. https ://doi.org/10.3389/fpls.2018.00945

Calder, I.R., 1991. Implications and assumptions in using the total counts and convection dispersion equations for tracer flow measurements with particular reference to transpiration measurements in trees. J Hydrol 125:149-158. https ://doi.org/10.1016/0022-1694(91)90088 -Y

Calder, I.R., Narayanswamy, M.N., Srinivasalu, N.V., Darling, W.G., Lardner, A.J., 1986. Investigation into the use of deuterium as a tracer for measuring transpiration from eucalypts. J Hydrol 84:345-351. https ://doi.org/10.1016/0022-1694(86)90132 -0

Calder, I.R., Kariyappa, G.S., Srinivasalu, N.V., Srinivasa, Murty, K.V., 1992. Deuterium tracing for the estimation of transpiration from trees Part 1. Field calibration. J Hydrol 130:17-25. https://doi.org/10.1016/0022-1694(92)90100 -A

Carrasco, L.O., Bucci, S.J., Francescantonio, D.D., Lezcano, O.A., Campanello, P.I., Scholz, F.G., Rodríguez, S., Madanes, N., Cristiano, P.M., Hao, G.-Y., Holbrook, N.M., Goldstein, G., 2014. Water storage dynamics in the main stem of subtropical tree species differing in wood density, growth rate and life history traits. Tree Physiol 35:354-365. https ://doi.org/10.1093/treep hys/tpu08 7 
Čermák, J., Kučera, J., Bauerle, W.L., Phillips, N., Hinckley, T.M., 2007. Tree water storage and its diurnal dynamics related to sap flow and changes in stem volume in old-growth Douglas-fir trees. Tree Physiol 27:181-198. https ://doi.org/10.1093/treep hys/27.2.181

Chapotin, S.M., Razanameharizaka, J.H., Holbrook, N.M., 2006a. Baobab trees (Adansonia) in Madagascar use stored water to flush new leaves but not to support stomatal opening before the rainy season. New Phytol 169:549-559. https ://doi.org/10.1111/j.1469-8137.2005.01618 .x

Chapotin, S.M., Razanameharizaka, J.H., Holbrook, N.M., 2006b. Water relations of baobab trees (Adansonia spp. L.) during the rainy season: does stem water buffer daily water deficits? Plant, Cell Environ 29:1021-1032. https ://doi.org/10.1111/j.1365-3040.2005.01456 .x

Chave, J., Coomes, D.A., Jansen, S., Lewis, S.L., Swenson, N.G., Zanne, A.E., 2009. Towards a worldwide wood economics spectrum. Ecol Lett 12(4):351-366. https ://doi.org/10.1111/j.1461-0248.2009.01285 .x

Dugas, W.A., Wallace, J.S., Allen, S.J., Roberts, J.M., 1993. Heat balance, porometer, and deuterium estimates of transpiration from potted trees. Agric For Meteorol 64:47-62. https ://doi.org/10.1016/0168-1923(93)90093 -W

Dye, P.J., Olbrich, B.W., Calder, I.R., 1992. A comparison of the heat pulse method and deuterium tracing method for measuring transpiration from Eucalyptus grandis trees. J Exp Bot 43:337343. https ://doi.org/10.1093/jxb/43.3.337

Fang, D., 2017. Water use, storage and transfer in tropical bamboos. Ph.D. thesis, Georg-AugustUniversität Göttingen

Gaines, K.P., Meinzer, F.C., Duffy, C.J., Thomas, E.M., Eissenstat, D.M., 2016. Rapid tree water transport and residence times in a Pennsylvania catchment. Ecohydrology 9:1554-1565. https ://doi.org/10.1002/eco.1747

Goldstein, G., Andrade, J.L., Meinzer, F.C., Holbrook, N.M., Cavelier, J., Jackson, P., Celis, A., 1998. Stem water storage and diurnal patterns of water use in tropical forest canopy trees. Plant Cell Environ 21:397-406. https ://doi.org/10.1046/j.1365-3040.1998.00273 .x

Hacke, U.G., Sperry, J.S., Pockman, W.T., Davis, S.D., McCulloh, K.A., 2001. Trends in wood density and structure are linked to prevention of xylem implosion by negative pressure. Oecologia 126:457-461. https ://doi.org/10.1007/s0044 20100628

Holbrook, N.M., 1995. Stem water storage. In: Gartner BL (ed) Plant stems: physiology and functional morphology. Academic Press, San Diego, pp 151-174. https ://doi.org/10.1016/B978-01227 6460-8/50009-6 
James, S.A., Meinzer, F.C., Goldstein, G., Woodruff, D., Jones, T., Restom, T., Mejia, M., Clearwater, M., Campanello, P., 2003. Axial and radial water transport and internal water storage in tropical forest canopy trees. Oecologia 134:37-45. https ://doi.org/10.1007/s0044 2-002-1080-8

Kalma, S.J., Thorburn, P.J., Dunn, G.M., 1998. A comparison of heat pulse and deuterium tracing techniques for estimating sap flow in Eucalyptus grandis trees. Tree Physiol 18:697-705. https ://doi.org/10.1093/treep hys/18.10.697

Lambs, L., Saenger, A., 2011. Sap flow measurements of Ceriops tagal and Rhizophora mucronata mangrove trees by deuterium tracing and lysimetry. Rapid Commun Mass Spectrom 25:27412748. https ://doi.org/10.1002/rcm.5098

Marc, V., Robinson, M., 2004. Application of the deuterium tracing method for the estimation of tree sap flow and stand transpiration of a beech forest (Fagus silvatica L.) in a mountainous Mediterranean region. J Hydrol 285:248-259. https ://doi.org/10.1016/j.jhydr ol.2003.09.001

Meinzer, F.C., James, S.A., Goldstein, G., Woodruff, D., 2003. Whole-tree water transport scales with sapwood capacitance in tropical forest canopy trees. Plant Cell Environ 26:1147-1155. https ://doi.org/10.1046/j.1365-3040.2003.01039 .x

Meinzer, F.C., James, S.A., Goldstein, G., 2004. Dynamics of transpiration, sap flow and use of stored water in tropical forest canopy trees. Tree Physiol 24:901-909. https ://doi.org/10.1093/treephys/24.8.901

Meinzer, F.C., Brooks, J.R., Domec, J.-C., Gartner, B.L., Warren, J.M., Woodruff, D.R., Bible, K., Shaw, D.C., 2006. Dynamics of water transport and storage in conifers studied with deuterium and heat tracing techniques. Plant Cell Environ 29:105-114. https ://doi.org/10.1111/j.13653040.2005.01404.x

Meinzer, F.C., McCulloh, K.A., Lachenbruch, B., Woodruff, D.R., Johnson, D.M., 2010. The blind men and the elephant: the impact of context and scale in evaluating conflicts between plant hydraulic safety and efficiency. Oecologia 164:287-296. https ://doi.org/10.1007/s0044 2-010-1734-x

Pfautsch, S., Adams, M.A., 2013. Water flux of Eucalyptus regnans: defying summer drought and a record heatwave in 2009. Oecologia 172:317-326. https ://doi.org/10.1007/s0044 2-012-24946

Phillips, N.G., Ryan, M.G., Bond, B.J., McDowell, N.G., Hinckley, T.M., Cermák, J., 2003. Reliance on stored water increases with tree size in three species in the Pacific Northwest. Tree Physiol 23:237-245. https ://doi.org/10.1093/treep hys/23.4.237 
Powers, J.S., Tiffin, P., 2010. Plant functional type classifications in tropical dry forests in Costa Rica: leaf habit versus taxonomic approaches. Funct Ecol 24:927-936. https ://doi.org/10.1111/j.1365-2435.2010.01701 .x

Reich, P.B., Borchert, R., 1984. Water stress and tree phenology in a tropical dry forest in the lowlands of Costa Rica. J Ecol 72:61-74. https ://doi.org/10.2307/22600 06 Scholz FG, Bucci SJ, Goldstein G, Meinzer FC, Franco AC,

Miralles-Wilhelm, F., 2007. Biophysical properties and functional significance of stem water storage tissues in Neotropical savanna trees. Plant Cell Environ 30:236-248. https ://doi.org/10.1111/j.1365-3040.2006.01623 .x

Schwendenmann, L., Dierick, D., Köhler, M., Hölscher, D., 2010. Can deuterium tracing be used for reliably estimating water use of tropical trees and bamboo? Tree Physiol 30:886-900. https ://doi.org/10.1093/treep hys/tpq04 5

Spannl, S., Volland, F., Pucha, D., Peters, T., Bräuning, A., 2016. Climate variability, tree increment patterns and ENSO-related carbon sequestration reduction of the tropical dry forest species Loxopterygium huasango of Southern Ecuador. Trees 30:1245-1258. https ://doi.org/10.1007/s0046 8-016-1362-0

Stratton, L., Goldstein, G., Meinzer, F.C., 2000. Stem water storage capacity and efficiency of water transport: their functional significance in a Hawaiian dry forest. Plant Cell Environ 23:99-106. https ://doi.org/10.1046/j.1365-3040.2000.00533 .x

Worbes, M., Blanchart, S., Fichtler, E., 2013. Relations between water balance, wood traits and phenological behavior of tree species from a tropical dry forest in Costa Rica—a multifactorial study. Tree Physiol 33:527-536. https ://doi.org/10.1093/treep hys/tpt028

Zanne, A.E., Lopez-Gonzalez, G., Coomes, D.A., Ilic, J., Jansen, S., Lewis, S.L., Miller, R.B., Swenson, N.G., Wiemann, M.C., Chave, J., 2009. Data from: towards a worldwide wood economics spectrum. Dryad Digital Repository. https ://doi.org/10.5061/dryad .234 


\subsection{Supplementary material Chapter 4}

Suppl. Table 4.1 Environmental conditions during the experiments in March and May 2015 (mean with SD in brackets).

\begin{tabular}{lllll}
\hline Altitude (m asl) & 670 & 670 & 860 & 1100 \\
\hline Month (2015) & March & May & March & March \\
Species studied & E. velutina & C. scabrida & E. velutina & E. velutina \\
& E. ruizii & G. spinosa & E. ruizii & E. ruizii \\
& C. trichistandra & & C. trichistandra & C. trichistandra \\
\hline VPD (kPa) & $0.8(0.3)$ & $0.7(0.2)$ & $0.3(0.2)$ & $0.2(0.1)$ \\
Temperature $\left({ }^{\circ} \mathrm{C}\right)$ & $27.9(1.9)$ & $27.5(1.6)$ & $22.1(1.0)$ & $20.6(0.7)$ \\
Relative humidity $(\%)$ & $68.4(9.7)$ & $67.8(5.8)$ & $90.3(7.6)$ & $94.7(4.5)$ \\
SWC $(\%)$ & $19.8(7.7)$ & $10.2(4.8)$ & $23.6(7.9)$ & $34.5(4.6)$ \\
\hline
\end{tabular}


Suppl. Table 4.2 Overview of D2O tracer amounts applied in different studies. When tracer amount was indicated per DBH, values were converted to tree circumference

\begin{tabular}{lll}
\hline Location & $\begin{array}{l}\text { Amount of } \mathrm{D}_{2} \mathrm{O} \text { tracer injected } \\
\left(\mathrm{ml} \mathrm{cm} \mathrm{circumference}{ }^{-1}\right)\end{array}$ & Reference \\
\hline Ecuador & $0.16 / 0.5$ & This study \\
India & 0.19 & Calder et al. (1986) \\
USA & 0.05 & Gaines et al. (2016) \\
Panama & Refers to Kamla et al. (1998) & James et al. (2003) \\
Australia & $0.017-0.06$ & Kamla et al. (1998) \\
USA & 0.5 & Meinzer et al. (2006) \\
Panama & Refers to Kamla et al. (1998) & Meinzer et al. (2003) \\
Philippines, Indonesia & Not indicated & Schwendenmann et al. (2010) \\
\hline
\end{tabular}




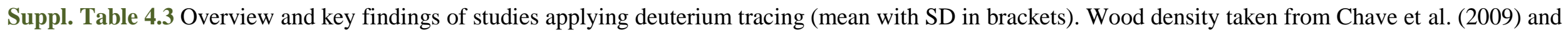
Zanne et al. (2009).

\begin{tabular}{|c|c|c|c|c|c|c|}
\hline Species & Location & $\mathrm{N}$ & $\mathrm{DBH}(\mathrm{cm})$ & Wood density $\left(\mathrm{g} \mathrm{cm}^{-3}\right)$ & $\mathrm{T}$ - residence (days) & Reference \\
\hline Capparis scabrida & Ecuador & 4 & $19.7(5.4)$ & $0.69()$. & $14.3(4.2)$ & This study \\
\hline Geoffroea spinosa & Ecuador & 4 & $28.2(4.9)$ & $0.75()$. & $10.8(6.3)$ & This study \\
\hline Erythrina velutina & Ecuador & 9 & $27.9(9.3)$ & $0.20()$. & $19.2(3.9)$ & This study \\
\hline Eriotheca ruizii & Ecuador & 10 & $56.4(17.3)$ & $0.47()$. & $18.8(2.4)$ & This study \\
\hline Ceiba trichistandra & Ecuador & 11 & $77.9(13.7)$ & $0.26()$. & $19.5(3.9)$ & This study \\
\hline Eucalyptus teretecornis & Southern India & 2 & $4.9(0.0)$ & $0.83()$. & $6.0(0.0)$ & Calder et al. (1986) \\
\hline Eucalyptus teretecornis & Southern India & 2 & $4.0(1.0)$ & $0.83()$. & $6.0(1.4)$ & Calder et al. (1992) \\
\hline Eucalyptus gunnii & UK & 1 & $5.0()$. & $0.83()$. & $5.0()$. & Dugas et al. (1993) \\
\hline Prunus serrulata & UK & 3 & $2.0(0.0)$ & $0.59()$. & $3.3(0.6)$ & Dugas et al. (1993) \\
\hline Eucalyptus grandis & South Africa & 2 & $14.5(4.9)$ & $0.66()$. & $7.5(6.2)$ & Dye et al. (1992) \\
\hline Acer saccharum & USA & 2 & $25.5(10.6)$ & $0.56()$. & $13.3(4.9)$ & Gaines et al. (2016) \\
\hline Carya tomentosa & USA & 3 & $33.0(11.1)$ & $0.64()$. & $11.0(1.5)$ & Gaines et al. (2016) \\
\hline Quercus prinus & USA & 3 & $36.7(10.6)$ & $0.57()$. & $10.9(9.3)$ & Gaines et al. (2016) \\
\hline Quercus rubra & USA & 3 & $40.7(10.1)$ & $0.56()$. & $17.4(5.0)$ & Gaines et al. (2016) \\
\hline Anacardium excelsum & Panama & 1 & $98.0()$. & $0.39()$. & $25.0()$. & James et al. (2003) \\
\hline Cordia alliodora & Panama & 1 & $34.0()$. & $0.52()$. & $5.0()$. & James et al. (2003) \\
\hline Ficus insipida & Panama & 1 & $65.0()$. & $0.38()$. & $9.0()$. & James et al. (2003) \\
\hline Schefflera morototoni & Panama & 1 & $47.0()$. & $0.46()$. & $26.0()$. & James et al. (2003) \\
\hline Eucalyptus grandis & Australia & 3 & $10.7(3.5)$ & $0.66()$. & $11.3(4.0)$ & Kalma et al. (1998) \\
\hline Ceriops tagal & Mayotte Island & 3 & $7.5(0.9)$ & $0.84()$. & $10.4(1.2)$ & Lambs and Saenger (2011) \\
\hline Rhizophora mucronata & Mayotte Island & 2 & $17.5(6.4)$ & $0.81()$. & $14.6(3.0)$ & Lambs and Saenger (2011) \\
\hline Fagus sylvatica & France & 3 & $10.9(4.1)$ & $0.59()$. & $14.0(1.0)$ & Marc and Robinson (2004) \\
\hline Pseudotsuga menziesii & USA & 6 & $53.7(56.2)$ & $0.43()$. & $50.0(19.2)$ & Meinzer et al. (2006) \\
\hline Tsuga heterophylla & USA & 2 & $91.0(2.8)$ & $0.42()$. & $59.0(2.8)$ & Meinzer et al. (2006) \\
\hline Bambusa blumeana & Philippines & 4 & $10.0(1.0)$ & $0.76()$. & $11.5(4.3)$ & Schwendenmann et al. (2010) \\
\hline Gliricidia sepium & Indonesia & 6 & $13.0(2.0)$ & $0.62()$. & $6.4(0.8)$ & Schwendenmann et al. (2010) \\
\hline Shorea contorta & Philippines & 5 & $18.0(7.0)$ & $0.43()$. & $4.5(0.3)$ & Schwendenmann et al. (2010) \\
\hline Shorea polysperma & Philippines & 5 & $14.0(2.0)$ & $0.51()$. & $3.8(0.6)$ & Schwendenmann et al. (2010) \\
\hline Swietenia macrophylla & Philippines & 5 & $15.0(1.0)$ & $0.52()$. & $3.9(0.3)$ & Schwendenmann et al. (2010) \\
\hline Theobroma cacao & Indonesia & 6 & $10.0(1.0)$ & $0.42()$. & $5.1(0.9)$ & Schwendenmann et al. (2010) \\
\hline
\end{tabular}


Suppl. Table 4.4 Key results from the deuterium tracing experiments of the deciduous species by altitude (mean with SD in brackets). ANOVA indicated no significant effects of altitude within one species.

\begin{tabular}{|c|c|c|c|c|c|c|c|}
\hline $\begin{array}{l}\text { Altitude } \\
\text { (m asl) }\end{array}$ & Species & $\begin{array}{l}\mathrm{N} \\
\text { (trees) }\end{array}$ & $\begin{array}{l}\text { T-arrival } \\
\text { (days) }\end{array}$ & $\begin{array}{l}\text { T-max } \\
\text { (days) }\end{array}$ & $\begin{array}{l}\text { T-residence } \\
\text { (days) }\end{array}$ & $\begin{array}{l}\mathrm{V}-\mathrm{D}_{2} \mathrm{O} \\
\left(\mathrm{m} \text { day }^{-1}\right)\end{array}$ & $\begin{array}{l}\text { WU-D }{ }_{2} \mathrm{O} \\
\left(\mathrm{kg} \mathrm{day}^{-1}\right)\end{array}$ \\
\hline \multirow{2}{*}{670} & Ceiba trichistandra & 2 & $1.0(0.0)$ & $3.0(3.5)$ & $20.0(1.0)$ & $20.0(4.0)$ & $339.3(331)$ \\
\hline & Erythrina velutina & 3 & $1.0(0.0)$ & $4.0(5.2)$ & $20.7(0.6)$ & $8.7(2.2)$ & $59.7(64.6)$ \\
\hline \multirow{2}{*}{860} & Ceiba trichistandra & 3 & $1.0(0.0)$ & $1.5(0.6)$ & $17.8(6.5)$ & $12.5(2.2)$ & $239.7(99.3)$ \\
\hline & Erythrina velutina & 3 & $1.0(0.0)$ & $6.0(1.7)$ & $17.0(6.9)$ & $8.2(4.7)$ & $59.9(55.7)$ \\
\hline \multirow{3}{*}{1100} & Ceiba trichistandra & 4 & $1.0(0.0)$ & $3.5(1.3)$ & $20.8(0.5)$ & $15.2(4.9)$ & $249.4(87.0)$ \\
\hline & Eriotheca ruizii & 3 & $1.0(0.0)$ & $2.0(0.0)$ & $17.0(4.4)$ & $15.6(3.2)$ & $190.1(43.2)$ \\
\hline & Erythrina velutina & 3 & $1.0(0.0)$ & $3.3(0.6)$ & $20.0(0.0)$ & $13.4(0.6)$ & $91.1(13.8)$ \\
\hline
\end{tabular}



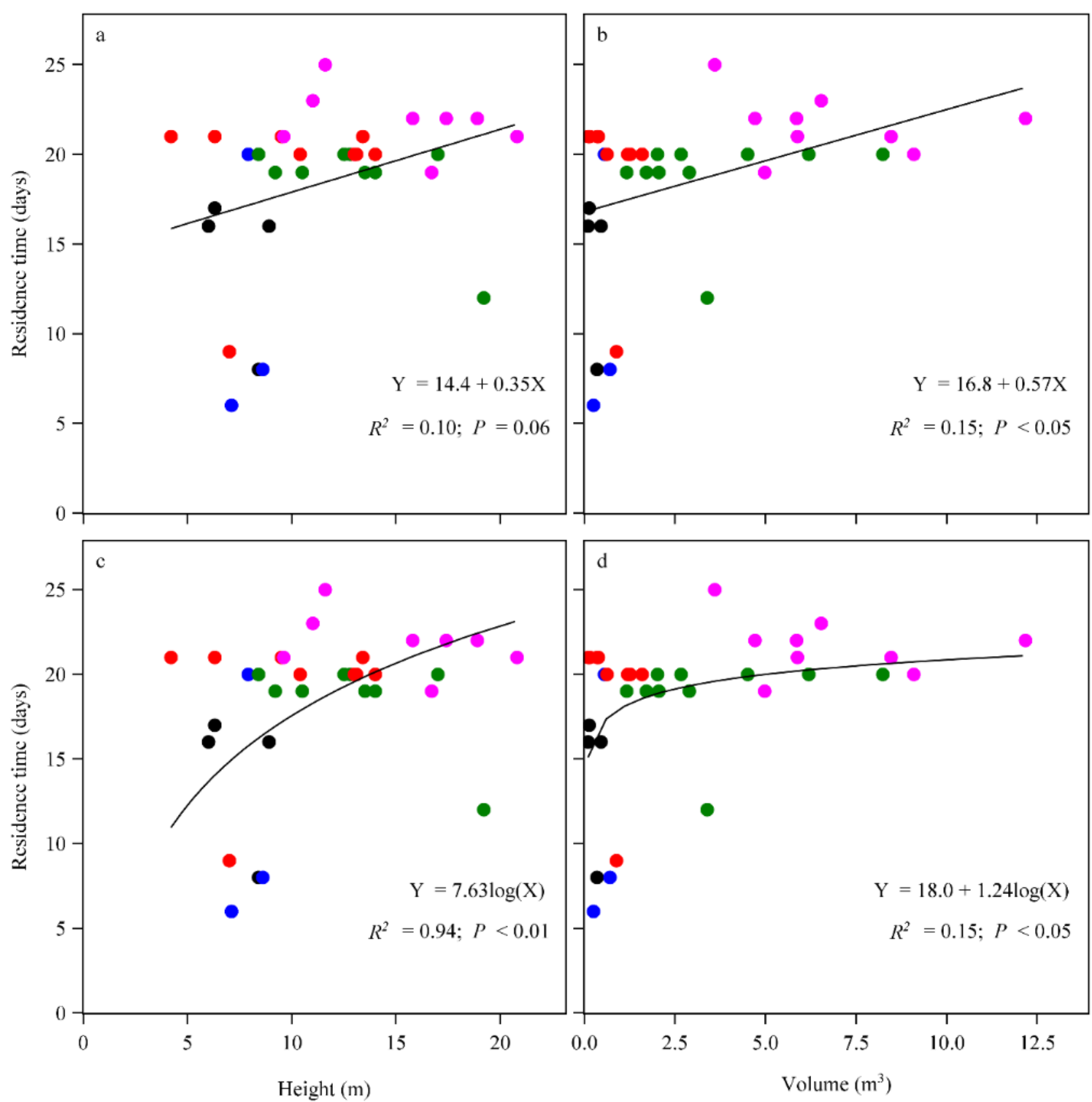

Suppl. Figure 4.1 Tracer residence time in relation to tree height (left) and stem volume (right), c + d show a log-transformed linear regression without intercept. 


\section{Chapter 5 Synthesizing drought coping strategies of Neotropical dry forest species}

\subsection{Consequences of moisture variations on phenology, stem water status and sap flux}

In regard to the recent global positive shift of dry forest extensions and the increasing impact of climate change on plant growth in tropical dry forest (TDF), this work intends to assemble the current knowledge on phenological and physiological patterns of functional plant-types under stress or drought conditions. Ecological significance of functional types found in TDF species with emphasis on interand intra-species variability in phenology, stem water status, sap flux and stem water storage were studied along an elevational gradient and compared to existing findings (Chapter 2-4). As complexity of dry forest characteristics under fluctuating moisture regimes is high (Figure 5.1), an additional objective was to find an easy and assessable drought indicator (Chapter 2).

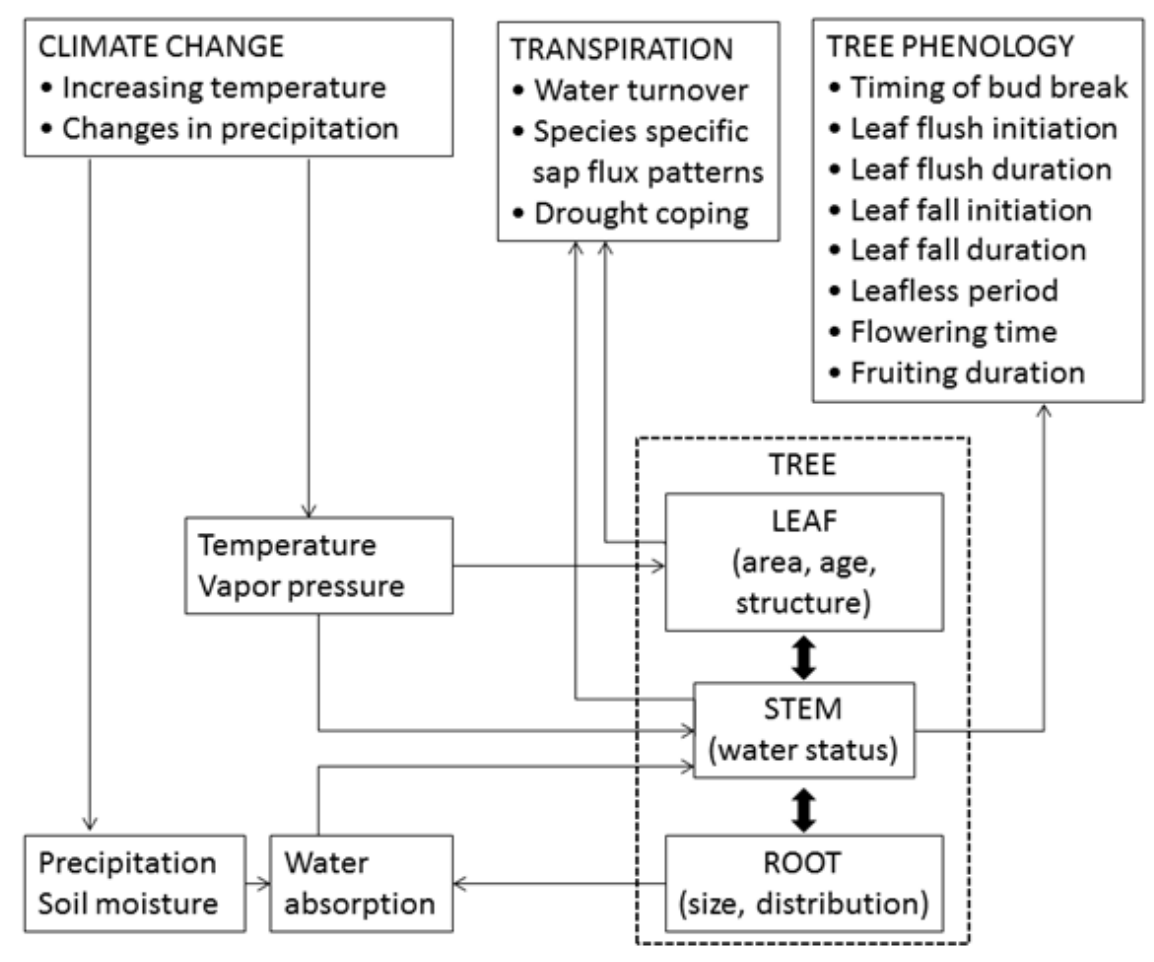

Figure 5.1 Climate change in relation to interactions amongst environmental inputs, stem water status of trees and its determinants, and phenological characteristics in dry tropics (adapted from Borchert, 1999). Direction of arrow is from the affecting to the affected factor.

Our phenological observations confirmed findings of other studies, especially for stem succulent species (Borchert (1994) in Costa Rican dry forests, Chapotin et al., (2006) in Madagascar, and Sing and Kushwaha (2016) in Indian Vindhyan dry forests). Leaf-flush for Ceiba was approximately one month before the onset of the wet season in mid-December (wet season: January to May), the deciduous species 
remained still leaf-less. During this time, a strong decrease in stem circumference was detected for Ceiba, indicating the utilization of stem water storage to enable the leaf-flushing (Chapter 2). This suggests that stored stem water through stem succulence is used to support an early leaf-flush, adding one month of phenological activity, which equals a gain of $20 \%$ in vegetation- and photosynthesis time (based on 5 months of wet season). Considering this hypothesis, contradictory findings have been reported for stem succulent Andansonia species (Baobab): Some trees use this phenological feature to maximize photosynthesis and start transpiration, whereas other trees were not transpiring during the first month without rainfall to keep water loss at a minimum (Chapotin et al., 2006a,b). The latter relates most likely to biomechanical reasons as stem succulent species are characterized by low wood density (large vessels for effective water transport) making them vulnerable to cavitation (e.g. Stratton et al., 2000; Pineda-García et al., 2015). This particularly might be the case for the Andansonia species, as highest sap flux was recorded directly underneath the bark (Chapotin et al., 2006b). Leaf-flush for Eriotheca and Erythrina was caused by the first rains in the early wet season, leaf fall for all three species uniformly at the end of the wet season, caused by declining precipitation rates. Contrary to our observations, other studies reported stem-succulent trees to shed their leaves earlier than co-occurring, non-succulent trees, often before the dry season, a pattern suggestive of a 'drought- avoidance' strategy (Owen, 1974; Fenner, 1980; Holbrook, 1995; Borchert and Rivera, 2001; Lobo et al., 2003). The evergreen Capparis was characterized by a continuously foliated canopy, tolerating drought conditions.

In TDFs, soil water availability can be considered the main factor limiting plant growth and therefore influencing species phenology (and distribution) (Borchert, 1994; Poorter et al., 2006; Poorter and Kitajima 2007; Dupuy et al., 2012). Throughout the greater study region, temporal intra-species variations in phenological key events (foliation, defoliation) were observed for the deciduous Eriotheca and Erythrina. Under similar climatic and geological conditions, varying topography with altering soil properties can create micro-sites which differ strongly in water availability (Borchert, 1994; OliveiraFilho et al., 1998; Segura et al., 2003; Dupuy et al., 2012), causing local intra-species differences. The growing habits of individuals of the same species growing at different sites, were even found to differ from leaf exchanging ('evergreen') to eight months deciduous (Singh and Kushwaha, 2016). For the stem succulent Ceiba this was not the case, all tree individuals, irrespective of location, flushed leaves at the same moment. At low latitudes, where annual variation of day length is less than one hour, this phenomenon was described by several authors as bud dormancy, which can be broken and induced by variations in the photoperiod (Borchert and Riviera, 2001; Lima et al., 2012; Borchert et al., 2015; Xu et al. 2016). The strong influence of precipitation on phenology was noted after an intermittent rain event in the early dry season, causing a short re-flush of leaves in Ceiba and Erythrina for approximately two weeks. This flexibility in leaf-fall timing of some deciduous (and stem succulent) species broadens the ecological range and adaptability within TDF ecosystems. Specifically, under the formulation of the differing possible precipitation scenarios (reduced rainfall during a given year, altered dry season length, altered timing of rainfall, reduced rainfall coupled with altered dry season length, or multi-year drought 
of sequential low rainfall years) (Allen et al., 2017) this finding indicates the adaptability of deciduous and hence drought avoiding species (in comparison to evergreen drought tolerating species). Generally, TDFs are widely distributed over precipitation gradients, indicating that their tree species are climatologically more 'generalists' in comparison to wet forest species, which have a lower tolerance for dry conditions (Esquivel-Muelbert et al., 2016).

When conditions where favorable in the mid-wet season (high soil water content, SWC), stem circumferences (as indicator for stem water status) for Ceiba and Eriotheca were strongly increasing. Both species reacted to rain events by rehydration of the trunk with a time lag of approximately four hours (three hours reported by Carrasco et al., 2014). Erythrina on the other hand did not show any response in stem circumference during early to mid-wet season (evergreen Capparis was due to material limitation not included in the dendrometer study). During declining soil moisture conditions (short dry spells during mid-wet season), Ceiba and Eriotheca responded by decreasing stem circumference (after approximately two weeks without rain), whereas Erythrina remained stable. From wet season maximum values, stem circumference strongly decreased during daytimes, when vapor pressure deficit (VPD) associated sap flux was high. During nights, stem circumferences increased until sunrise. Main causes for the fluctuations of stem circumference are diurnal changes of environmental conditions (Goldstein et al., 1998; Turcotte et al., 2009; Krepkowski et al., 2011; King et al., 2013), as synchronization of the contraction phase and high temperatures indicate that evapotranspiration and water loss through the canopy, trigger stem shrinkage (Mendivelso et al., 2016). The different phases of stem contraction, recovery, and increment in this study were also described by Deslauriers et al. (2007). Towards the late wet season high transpiration under low SWC (monthly mean of $9.8 \pm 3.7 \%$ in May) caused strong stem contractions for Ceiba and Eriotheca. After approximately two weeks of low SWC, also sap flux and phenology were affected. Accordingly, species at the lowest site reduced sap flux sensitively (Ceiba 20\%, Eriotheca $40 \%$ and Erythrina 50\%) followed by leaf shedding, whereas trees at the highest altitude were not yet affected as SWC remained high $(20.3 \pm 3.9 \%)$. The elevational gradient causes increased length of the leaved period of all species, noticeable through the responses to the different moisture regimes. Using seasonal changes in stem diameter as an indirect measure of changes in tree water status, we found that leaf shedding followed increasing water stress during early drought. For Ceiba and Eriotheca shortly after the leaf-fall a rehydration of the stem was recorded by increasing circumference even under limiting soil moisture conditions. Eriotheca decreased stem circumference slowly over the course of the dry season, whereas Ceiba retained a stable circumference until one month before the onset of the wet season when leaves were flushed. Trees tend to rehydrate after leaf shedding, and rehydration normally precedes flowering or flushing (Borchert 1980, 1991, 1994, Reich and Borchert 1982, 1984), which in our case was after the dry season. The high importance and influence of physiological traits like stem water status for phenology as in our study was described throughout TDFs (e.g. Borchert, 1994; Mendez-Alonzo et al., 2013). 
A typical scaling-relationship between tree water use and diameter at breast height (DBH) could be established, which corresponds to other studies (e.g. James et al., 2003; Meinzer et al., 2005; Kunert et al., 2012). Nevertheless, this relationship was stronger under favorable conditions than unfavorable conditions (Chapter 3). We thus analyzed the physiological processes of tree water use patterns according to two contrasting SWC schemes (SWC $>25 \%$ vs SWC $<15 \%$ ), which was rather infrequently assessed before (Meinzer et al., 2010). Here, sap flux patterns revealed functional, type specific responses: The deciduous species increased sap flux densities with increasing SWC, whereas the evergreen Capparis reduced it under high SWC. Under wet conditions and additional high VPD all species increased sap flux densities (Figure 3.5). This pattern contrasts the findings of Worbes et al. (2013) in a Costa Rican dry forest, where considerable interspecies differences were recorded under similar functional schemes: Stem succulents showed a pronounced midday depression in stomatal conductance, but the pattern of the stomatal conductance of the other species (deciduous, brevideciduous and evergreen) followed the varying intensity of photosynthetic active radiation (Worbes et al., 2013). When SWC declined below $15 \%$ in the present study, all deciduous species reduced their sap flux density values, whereas the evergreen Capparis increased sap flux density. Under these dry conditions VPD values where high, causing high sap flux densities of the evergreen Capparis. This constant water loss under dry conditions can only be explained by ground-water access through a deep root system, as found for evergreen tree species in Asian monsoon forests (Elliot et al., 2006). Under dry conditions at higher elevation the correlations of sap flux density and VPD for Eriotheca and Erythrina disappeared leading to declining sap flux rates, whereas the stem succulent Ceiba kept transpiring at higher rates (Figure 3.5). This disconnection of sap flux densities and VPD for the deciduous species might indicate an increased stomatal control to cope with the dry conditions, which was also suggested by Worbes et al. (2013) for stem succulent species. A mixed effect model (Model 1) proved significant effects of VPD, species, elevation and DBH on sap flux density. Capparis had low sap flux sensitivity to SWC, but reacted highly sensitive to VPD (Figure 3.3). The two deciduous species (Eriotheca, Erythrina) showed contrary patterns, indicating a stronger control of SWC than VPD. Stem succulent Ceiba reacted similarly sensitive to SWC and VPD; it was the moderate (considering sensitivity to environmental drivers) species in the setup. These findings in association with the stem water content for Ceiba indicates that greater xylem capacitance can buffer tension, reducing the risk of hydraulic failure and enabling the species to keep transpiring (Meinzer et al., 2008). Diurnal hysteresis loops for all four species under the two moisture regimes underlined that only Capparis was able to increase sap flux densities under dry conditions (Figure 3.6). For the stem succulent Ceiba the area of the hysteresis was slightly larger than for the two deciduous species, but indicated no use of stored water to overcome dry spells, a finding not to be expected but confirmed by Chapotin et al. (2006a). Ceiba speciosa in contrast, which is a stem succulent tree species characterized by low wood density and high capacitance, was found to discharge large quantities of water into the transpirational stream originating from the internal stem storage (Carrasco et al., 2014). In general, stem water 
dynamics are known to play an important role as an intermediate source of water for transpiration (Goldstein et al., 1998; Meinzer et al., 2001) in tropical as well as temperate regions with a contribution to total transpiration (in soft- and hardwood species) from 10 to 50\% (Carrasco et al., 2014). Species with higher water storage capacity and capacitance may thus have an enhanced ability to buffer temporary canopy water use peaks at midday and during periods with low soil water availability.

For the tracing study with Deuterium Oxide (D2O), an additional evergreen species (Geoffrea spinosa) was included in the set-up. Tracer velocities were found in the range of 5.6-15.0 $\mathrm{m} \mathrm{day}^{-1}$, and were significantly lower in the two evergreen species compared to the three deciduous species, with lowest values for Geoffroea and highest for Ceiba. Tracer residence time was also significantly different between evergreen and deciduous species (11-14 vs. 19-22 days). Longest residence time was found in the stem succulent Ceiba with a positive relationship between residence time and tree size. Generally, tracer residence time is supposed to increase with tree diameter as shown by a synthesis of several studies (Figure 4.2a), and relative water storage capacity was found to be highest in large trees (James et al., 2003; Meinzer et al., 2004). From the present study as well as from the literature survey (Figure 4.2b), tracer residence time significantly and negatively correlated to wood density, and a speciesindependent scaling of sapwood capacitance with wood density could be established (Stratton et al., 2000; Scholz et al., 2007). Ceiba and Erythrina, the two species with the lowest wood density in the study ( $0.21 \mathrm{~g} \mathrm{~cm}^{-3}$ and $0.2 \mathrm{~g} \mathrm{~cm}^{-3}$, respectively), exhibited the longest tracer residence times, despite being of different functional types. Both seem to maximize photosynthetic rates at all costs and risks by transpiring at high rates, avoiding possible embolism due to fast shedding of leaves (Erythrina) or having large water reservoirs (Ceiba). For the evergreen species in contrast it seems to be advantageous to have a rather short stature and high wood density (e.g. $0.75 \mathrm{~g} \mathrm{~cm}^{-3}$ for Geoffroea and $0.69 \mathrm{~g} \mathrm{~cm}^{-3}$ for Capparis; Chave et al., 2009; Zanne et al., 2009), enabling a better adaptation to resist drought-induced embolism and to assure water transport under high demand (Hacke et al., 2001).

Deciduous and evergreen species are expected to differ in their xylem hydraulic design, with deciduous species being hydraulically more efficient but more prone to cavitation than evergreen species (Ackerly, 2004; Maherali et al., 2004; Markesteijn et al., 2011). This could relate to the negative correlation of vessel size and vessel density, demonstrating a trade-off between efficiency and safety of water transport (Tyree et al., 1994). In drought-dominated environments efficient water transport is connected to large vessels versus small vessels for safety against embolism (Worbes et al., 2013). Interestingly it was found that the size of the vessels is influenced considerably by the size of the individual tree: Tall trees tend to have larger vessels than smaller trees in all tropical climate types (Fichtler and Worbes, 2012). In our study, small statured trees including the evergreen Capparis had daily water use rates of less than $20 \mathrm{~kg}$ day $^{-1}$, whereas the largest individual of the stem succulent Ceiba reached water use rates of about 140 $\mathrm{kg} \mathrm{day}^{-1}$. Additionally, Ceiba displayed a bell-shaped radial flux profile where maximum sap flux was located at 2-3 cm depth and therefore protected by the outer low-conducting xylem (Suppl. Figure 3.3). 
Because deciduous and evergreen leaves represent different poles of the leaf economic spectrum, this link between leaf phenology and conductive performance clearly predicts stem and leaf integration and will influence tree size (Dìaz et al., 2004; Freschet et al., 2010).

Criteria for indicator selection should emphasize on utility and significance for users, analytical soundness, and measurability of the ecological indicator (OECD 1993). If therefore the suggested causal relations between seasonal drought and phenology are accurate, then species-specific phenological patterns should vary predictably with seasonal climate throughout a species range and, inversely, should be biological indicators of environmental seasonality (Borchert, 1996). As climate change impact can be better evaluated at the level of functional types, based on the duration of deciduousness (Singh and Kushwaha, 2016), particularly Ceiba is proposed as indicator species (Chapter 2 and Chapter 3).

\subsection{Outlook and potential indicator use}

By our attempt to evaluate tree water use dynamics and phenology to derive a drought based indicator (Chapter 2) and to further understand if there are species' specific drought coping strategies, we were able to discuss some functional ecotype related water use traits (Chapter 3). Examining stem water residence time allowed to further hypothesize how structural traits might affect water use and influence drought coping strategies (Chapter 4). We were able to give insights to the extent of avoiding or tolerating drought in different functional types, which might help support the development of drought response scenarios for TDFs as threatened ecosystem. Nevertheless, each dry forest seems to have a unique set of factors (depending on species composition, geology, expositions etc.) that influences their hydrological cycles and thereby the capacity to cope with changing seasonal scenarios. Future studies will have to create a global continuous, satellite-based monitoring system for forest areas, collecting ecological information such as leaf level drought responses and phenological patterns to globally provide open access, live data for researchers. Likewise, the entire plant water use should be assessed in greater detail, to allow a better ecosystem modelling enabling the prediction of most likely change scenarios. 


\subsection{References Chapter 5}

Ackerly, D., 2004. Functional strategies of chaparral shrubs in relation to seasonal water deficit and disturbance. Ecological Monographs 74:25-44.

Allen, K., Dupuy, J.M., Gei, M.G., Hulshof, C., Medvigy, D., Pizano, C., Salgado-Negret, B., Smith, C.M., Trierweiler, A., Van Bloem, S.J., Waring, B.G., Xu, X. and Powers, J.S., 2017. Will seasonally dry tropical forests be sensitive or resistant to future changes in rainfall regimes? Environ. Res. Lett. 12. doi: https://doi.org/10.1088/1748-9326/aa5968

Borchert. R., 1980. Phenology and ecophysiology of tropical trees: Erythrina poeppigiana 0. F. Cook. Ecology, 61, 1065-1074.

Borchert, R., 1991. Growth periodicity and dormancy. In: AS. Raghavendra (ed.), Physiology of trees: 221-245.

Borchert, R., 1994. Induction of rehydration and bud break by irrigation or rain in deciduous trees of a tropical dry forest in Costa Rica. Trees 8, 198-204. doi: 10.1007/BF00196847

Borchert, R., 1996. Phenology and flowering periodicity of Neotropical dry forest species: evidence from herbarium collections. Trop. Ecol. 12, 64-80. doi: 10.1017/S0266467400009317

Borchert R, Rivera G., 2001. Photoperiodic control of seasonal development and dormancy in tropical stemsucculent trees. Tree Physiology 21: 213-221.

Carrasco, L.O., Bucci, S.J., Francescantonio, D.D., Lezcano, O.A., Campanello, P.I., Scholz, F.G., Rodríguez, S., Madanes, N., Cristiano, P.M., Hao, G.Y., Holbrook, N.M., Goldstein, G., 2014. Water storage dynamics in the main stem of subtropical tree species differing in wood density, growth rate and life history traits. Tree Physiology 87: doi:10.1093/treephys/tpu087.

Chapotin, S.M., Razanameharizaka, J.H., and Holbrook, N.M., 2006a. Baobab trees (Adansonia) in Madagascar use stored water to flush new leaves but not to support stomatal opening before the rainy season. New Phytol. 169, 549-559. doi: 10.1111/j.1469-8137.2005.01618.x

Chapotin, S.M., Razanameharizaka, J.H., Holbrook, N.M., 2006b. Water relations of baobab trees (Adansonia L.) during the rainy season: does stem water buffer daily water deficits? Plant, Cell \& Environment. doi:10.1111/j.1365-3040.2005.01456.x

Chave, J, Coomes, D.A., Jansen, S., Lewis, S.L., Swenson, N.G., Zanne, A.E., 2009. Towards a worldwide wood economics spectrum. Ecology Letters 12(4):351-366. https://doi.org/10.1111/j.14610248.2009.01285.x

Deslauriers, A., Rossi, S., Anfodillo, T., 2007. Dendrometer and intra-annual tree growth: what kind of information can be inferred? Dendrochronologia 25, 113-124. 
Díaz, S., Hodgson, J.G., Thompson, K., Cabido, M., Cornelissen, J.H.C., Jalili, A., Montserrat-Martí, G., Grime, J.P., Zarrinkamar, F., Asri, Y., Band, S.R., Basconcelo, S., Castro-Díez, P., Funes, G., Hamzehee, B., Khoshnevi, M., Pérez-Harguindeguy, N., Pérez-Rontomé, M.C., Shirvany F.A., Vendramini, F., Yazdani, S., Abbas-Azimi, R., Bogaard, A., Boustani, S., Charles, M., Dehghan, M., de Torres-Espuny, L., Falczuk, V., Guerrero-Campo, J., Hynd, A., Jones, G., Kowsary, E., Kazemi-Saeed, F., MaestroMartínez, M., Romo-Díez, A., Shaw, S., Siavash, B., Villar-Salvador, P., Zak, M.R., 2009. The plant traits that drive ecosystems: Evidence from three continents. Journal of Vegetation Science 15:295-304.

Dupuy, J.M., Hernandez-Stefanoni, J.L., Hernandez-Juarez, R.A., Tetetla-Rangel, E., Lopez-Martínez, J.O., Leyequién-Abarca, E., Tun-Dzul, F.J., and May-Pat, F., 2012. Patterns and Correlates of Tropical Dry Forest Structure and Composition in a Highly Replicated Chronosequence in Yucatan, Mexico. Biotropica 44(2): 151-162. doi: 10.1111/j.1744-7429.2011.00783.x.

Elliot, S., Baker, P., Borchert, R., 2006. Leaf flushing during the dry sea- son: the paradox of Asian monsoon forests. Glob Ecol Biogeogr 15:248-257.

Esquivel-Muelbert, A., Baker, T.A., Dexter, K.G., Lewis, S.L., ter Steege, H., Lopez-Gonzalez, G., Mendoza, A.M., Brienen, R., Feldpausch, T.R., Pitman, N., Alonso, A., van der Heijden, G., Peña-Claros, M., Ahuite, M., Alexiaides, M., Dávila, E.A., Murakami, A.A., Arroyo, L., Aulestia, M., Balslev, H., Barroso, J., Boot, R., Cano, A., Moscoso, V.C., Comiskey, J.A., Cornejo, F., Dallmeier, F., Daly, D.C., Dávila, N., Duivenvoorden, J.F., Montoya, A.J.D., Erwin, T., Di Fiore, A., Fredericksen, T., Fuentes, A., García-Villacorta, R., Gonzales, T., Guevara Andino, J.A., Honorio Coronado, E.N., HuamantupaChuquimaco, I., Jiménez-Rojas, E.M., Killeen, T.J., Malhi, Y., Mendoza, C., Mogollón, H., Møller Jørgensen, P., Montero, J.C., Mostacedo, B., Nauray, W., Neill, D., Vargas, P.N., Palacios, S., Cuenca, W.P., Camacho, N.C.P., Peacock, J., Phillips, J.F., Pickavance, G., Quesada, C.A., Ramírez-Angulo, H., Restrepo, Z., Rodriguez, C.R., Ríos Paredes, M., .Peñuela-Mora, M.C., Sierra, R., Silveira, M., Stevenson, P., Stropp, J., Terborgh, J., Tirado, M., Toledo, M., Torres-Lezama, A., Umaña, M.N., Urrego, L.E., Vasquez Martinez, R., Gamarra, L.V., Vela, C.I.A., Torre, E.V., Vos, V., von Hildebrand, P., Vriesendorp, C., Wang, O., Young, K.R., Zartman, C.E., and Phillips, O.L., 2016. Seasonal drought limits tree species across the Neotropics. Ecography 40: 618-629, 2016 doi: 10.1111/ecog.01904

Fenner, M., 1980. Some measurements on the water relations of baobab trees. Biotropica 12, 205-209

Fichtler, E., Worbes, M., 2012. Wood anatomical variables in tropical trees and their relation to site conditions and individual tree morphology. IAWA J 33:119-140.

Freschet, G.T., Cornelissen, J.H.C., van Logtestijn, R.S.P., Aerts, R., 2010. Evidence of the 'plant economics spectrum' in a subarctic flora. Journal of Ecology 98:362- 373. 
Goldstein, G., Andrade, J.L., Meinzer, F.C., Holbrook, N.M., Cavelier, J., Jackson, P., Celis, A., 1998. Stem water storage and diurnal patterns of water use in tropical forest canopy trees. Plant Cell Environ. 21, 397-406. http://dx.doi.org/10.1046/ j.1365-3040.1998.00273.x

Hacke, U.G., Sperry, J.S., Pockman, W.T., Davis, S.D., McCulloh, K.A., 2001. Trends in wood density and structure are linked to prevention of xylem implosion by negative pressure. Oecol 126:457-461. https://doi.org/10.1007/s004420100628

Holbrook, N.M., 1995. Stem water storage. In: Gartner BL, ed. Plant Stems: Physiology and Functional Morphology. San Diego, CA, USA: Academic Press, 151-174.

James, S.A., Meinzer, F.C., Goldstein, G., Woodruff, D., Jones, T., Restom, T., Mejia, M., Clearwater, M., and Campanello, P., 2003. Axial and radial water transport and internal water storage in tropical forest canopy trees. Oecol 134:37-45. https://doi.org/10.1007/s00442-002-1080-8

King, G., Fonti, P., Nievergelt, D., Büntgen, U., Frank, D., 2013. Climatic drivers of hourly to yearly tree radius variations along a $6{ }^{\circ} \mathrm{C}$ natural warming gradient. Agric. For. Meteorol. 168, 36-46, http://dx.doi.org/10.1016/j.agrformet.2012. 08.002.

Krepkowski, J., Bräuning, A., Gebrekirstos, A., Strobl, S., 2011. Cambial growth dynamics and climatic control of different tree life forms in tropical mountain forest in Ethiopia. Trees 25, 59-70. http://dx.doi.org/10.1007/s00468-010- 0460-7.

Kunert, N., Schwendenmann, L., Potvin, C., Hölscher, D., 2012. Tree diversity enhances tree transpiration in a Panamanian forest plantation. J. Appl. Ecol. 49, 135-144. doi: 10.1111/j.1365-2664.2011.02065.x

Lima, R.A.F., Rother, D.C., Muler, A.E., Lepsch, I.F., Rodrigues, R.R., 2012. Bamboo overabundance alters forest structure and dynamics in the Atlantic Forest hotspot. Biol Conserv 147:32-39.

Lobo, J.A., Quesada, M., Stoner, K.E., Fuchs, E.J., Herrerías-Diego, Y., Rojas, J., Saborío, G., 2003. Factors affecting phenological patterns of Bombacaceous trees in seasonal forests in Costa Rica and Mexico. American Journal of Botany 90: 1054-1063.

Maherali, H., Pockman, W. T., Jackson, R.B., 2004. Adaptive variation in the vulnerability of woody plants to xylem cavitation. Ecology 85:2184-2199.

Markesteijn, L., Poorter, L., Paz, H., Sack, L., Bongers, F., 2011. Ecological differentiation in xylem cavitation resistance is associated with stem and leaf structural traits. Plant, Cell Environment 34:137-148.

Meinzer, F.C., Goldstein, G., Andrade, J.L., 2001. Regulation of water flux through tropical forest canopy trees: Do universal rules apply? Tree Physiol. 21, 19-26. 
Meinzer, F.C., James, S.A., Goldstein, G., 2004. Dynamics of transpiration, sap flow and use of stored water in tropical forest canopy trees. Tree Physiology 24, 901-909.

Meinzer, F.C., Bond, B.J., Warren, J.M., Woodruff, D.R., 2005. Does water transport scale universally with tree size? Funct. Ecol. 19, 558-565. doi: 10.1111/j.1365-2435.2005.01017.x

Meinzer, F.C., Woodruff, D.R., Domec, J.C., Goldstein, G., Campanello, P.I., Gatti, M.G., Villalobos-Vega, R., 2008. Coordination of leaf and stem water transport properties in tropical forest trees. Oecologia 156:3141.

Meinzer, F.C., McCulloh, K.A., Lachenbruch, B., Woodruff, D.R., Johnson, D.M., 2010. The blind men and the elephant: the impact of context and scale in evaluating conflicts between plant hydraulic safety and efficiency. Oecologia 164:287-296.

Mendez-Alonzo, R., Pineda-Garcia, F., Paz, H., Rosell, J.A., Olson, M.E., 2013. Leaf phenology is associated with soil water availability and xylem traits in a tropical dry forest. Trees - Structure and Function 27: $745-754$

Mendivelso, H.A., Camarero, J.J., Gutiérrez, E., 2016. Climatic influences on leaf phenology, xylogenesis and radial stem changes at hourly to monthly scales in two tropical dry forests. Agric. For. Meteorol. 216, $20-36$.

OECD, 1993. OECD Core Set of Indicators for Environmental Performance Reviews. Organisation for Economic Cooperation and Development, Paris.

Oliveira-Filho, A.T., Curi, N., Vilela, E.A., Carvahlo, D.A., 1998. Effects of canopy gaps, topography and soils on the distribution of woody species in a central Brazilian deciduous dry forest. Biotropica 30: 362-375

Owen, J., 1974. A contribution to the ecology of the African baobab (Adansonia digitata L.). Savanna 3: 1-12.

Pineda-García, F., Paz, H., Meinzer, F.C., Angeles, G., 2015. Exploiting water versus tolerating drought: wateruse strategies of trees in a secondary successional tropical dry forest. Tree Physiology 36, 208-217. doi:10.1093/treephys/tpv124

Poorter, L., Bongers, L., Bongers, F., 2006. Architecture of 54 moist forest species: Traits, trade-offs, and functional groups. Ecology 87: 1289-1301.

Poorter, L., Kitajima, K., 2007. Carbohydrate storage and light requirements of tropical moist and dry forest tree species. Ecology 88: 1000- 1011.

Reich, P.B., Borchert, R., 1982. Phenology and ecophysiology of the tropical tree, Tabebuia neochrysantha (Bignoniaceae). Ecology, 63, 294-299. 
Reich, P.B., Borchert, R., 1984. Water stress and tree phenology in a tropical dry forest in the lowlands of CostaRica. Journal Ecol. 72:61-74

Scholz, F.G., Bucci, S.J., Goldstein, G., Meinzer, F.C., Franco, A.C., Miralles-Wilhelm, F., 2007. Biophysical properties and functional significance of stem water storage tissues in Neotropical savanna trees. Plant Cell Environ 30:236-248. https://doi.org/10.1111/j.1365-3040.2006.01623.x

Segura, G., Balvanera, P., Duran, E., Perez, A., 2003. Tree community structure and stem mortality along a water availability gradient in a Mexican tropical dry forest. Plant Ecol. 169: 259-271.

Singh, K.P., Kushwaha, C.P., 2016. Deciduousness in tropical trees and its potential as indicator of climate change: a review. Ecol. Indic. 69, 699-706.

Stratton, L., Goldstein, G., Meinzer, F.C., 2000. Stem water storage capacity and efficiency of water transport: their functional significance in a Hawaiian dry forest. Plant Cell Environ 23:99-106

Turcotte, A., Morin, H., Krause, C., Deslauriers, A., Thibeault-Martel, M., 2009. The timing of spring rehydration and its relation with the onset of wood formation in black spruce. Agric. For. Meteorol. 149, 1403-1409. http://dx.doi.org/10.

Tyree, M.T., Davis, S.D., Cochard, H., 1994. Biosphysical perspectives of xylem evolution: is there a tradeoff of hydraulic efficiency for vulnerability to dysfunction? IAWA J 115:335-360.

Worbes, M., Blanchart, S., Fichtler, E., 2013. Relations between water balance, wood traits and phenological behavior of tree species from a tropical dry forest in Costa Rica - A multifactorial study. Tree Physiology 33, 527-536. doi:10.1093/treephys/tpt028

Xu, X., Medvigy, D., Powers, J.S., Becknell, J.M., Guan, K., 2016. Diversity in plant hydraulic traits explains seasonal and inter-annual variations of vegetation dynamics in seasonally dry tropical forests. New Phytologist 212: 80-95. doi: 10.1111/nph.14009

Zanne, A.E., Lopez-Gonzalez, G., Coomes, D.A., Ilic, J., Jansen, S., Lewis, S.L., Miller, R.B., Swenson, N.G., Wiemann, M.C., Chave, J., 2009. Data from: Towards a worldwide wood economics spectrum. Dryad Digital Repository. https://doi.org/10.5061/dryad.234 


\section{Index of figures}

Figure 1.1 Global distribution of tropical dry forest in the year 2000, displayed as 10-km cells containing this forest type (including plantations in tropical dry forest areas) (Miles et al. 2006).

Figure 1.2 Ceiba trichistandra at the end of the dry season (December) is already flushing new foliage, while the other deciduous species remain leafless for another month.

Figure 1.3 Map of Ecuador with study area shown in the south western tropical dry forest region. (adapted from Spannl et al., 2013)

Figure 1.4 Studied tree species from left to right: Ceiba trichistandra (stem succulent deciduous), Eriotheca ruizii (deciduous), Erythrina velutina (brevi-deciduous) and Capparis scabrida (evergreen) fully leaved during the wet season.

Figure 2.1 Climate diagram of the study area, error bars show SD.

Figure 2.2 Mean cumulative stem diameter for E. ruizii, C. trichistandra and E. velutina calculated from 12 individuals each during the study period from April 2014 to January 2016. Numbered arrows indicate bud break, leaf flushing, leaf shedding and re-flushing after a rain event. Light grey bars indicate the length of the wet season, small dark grey bars indicate the examined periods characterized by distinct soil water conditions

Figure 2.3 Change of foliation for C. trichistandra, E. ruizii and E. velutina during two consecutive years within the study period. The course of foliation for E. ruizii and E. velutina was observed to be the same over the course of the study.

Figure 2.4 Start of wet season, course over five consecutive days (9.2.-13.2.2015) of diel change in stem circumference ( $\Delta$ Circumference measurements, solid line) and sap flux density (Js measurements, dashed line) for $\mathrm{n}=4$ individuals per species and plot. Vapor pressure deficit (VPD, solid line) and volumetric soil water content (SWC, dashed line) is shown for all three elevations, medium precipitation $(30 \mathrm{~mm})$ was recorded earlier on Feb.7th, $2 \mathrm{~mm}$ precipitation on Feb. 9th,followed by dry conditions. Missing data for E. ruizii and E. velutina at $670 \mathrm{~m}$ asl. due to maintenance during this observation period. Error bars represent standard deviation.

Figure 2.5 Middle of wet season (decreasing soil water level),course over five consecutive days (6.3.10.3. 2015) of diel change in stem circumference ( $\Delta$ Circumference measurements, solid line) and sap flux density (Js measurements, dashed line)for $\mathrm{n}=4$ individuals per species and plot. Vapor pressure deficit (VPD, solid line) and volumetric soil water content (SWC, 
dashed line) is shown for all three elevations, little precipitation $(15 \mathrm{~mm})$ was recorded earlier, followed by two weeks of dry conditions. Missing sap flux data due to power shortages. Error bars represent standard deviation.

Figure 2.6 Middle of wet season (increasing soil water level),course over five consecutive days (16.3.20.3. 2015) of diel change in stem circumference ( $\Delta$ Circumference measurements, solid line) and sap flux density (Js measurements, dashed line)for $\mathrm{n}=4$ individuals per species and plot. Vapor pressure deficit (VPD, solid line) and volumetric soil water content (SWC, dashed line) is shown for all three elevations, earlier no precipitation was recorded, it rained on 18th of March during the displayed period and continued raining. Missing sap flux data due to power shortages. Error bars represent standard deviation.

Figure 2.7 End of wet season,course over fiveconsecutive days (20.5.-25.5.2015) of diel change in stem circumference ( $\Delta$ Circumference measurements, solid line) and sap flux density (Js measurements, dashed line)for $\mathrm{n}=4$ individuals per species and plot.Vapor pressure deficit (VPD, solid line) and volumetric soil water content (SWC, dashed line) is shown for all three elevations, no precipitation was recorded earlier nor during the displayed period. Missing sap flux data due to power shortages. Error bars represent standard deviation.

Figure 2.8 Course over five consecutive days of diel change in stem circumference (dendrometer measurements, solid line) and sap flux density (TDP measurements, dashed line) at 670m asl., after 5mm of precipitation during April 2014 (upper panel, 30.4.-4.5.2014) $C$. trichistandra was completely defoliated and displayed no sap flux patterns, and after $70 \mathrm{~mm}$ of precipitation during May 2014 (lower panel, 25.5.-29.5.2014) C. trichistandra was able to re-flush some leafs which led to increased sap flux rates.

Figure 2.9 Changes in stem circumference during parts of the wet (March-April) and dry season (November), grey shading indicates the different phases of stem variation (increment, recovery, and contraction) for the indicated time for each day of the month, grey line displays diurnal changes of air temperature $\left({ }^{\circ} \mathrm{C}\right)$. Data are derived from band dendrometer recordings.

Figure 3.1 Daily sap flux densities $\left(J_{\mathrm{s}}\right)(\mathrm{n}=4$ trees per elevation) of the four study species as well as vapor pressure deficit (VPD, values at $670 \mathrm{~m}$ were adopted from $860 \mathrm{~m}$ asl.) and soil water content (SWC) over the whole study period in the year 2015, grey shaded area indicates foliated period, error bars indicate standard deviation.

Figure 3.2 Relationship between mean daily tree water use and tree diameter (DBH), $n=40, p<0.001$. 
Figure 3.3 Comparison of sap flux density response to SWC and VPD for species over elevation to measure sap flux sensitivity in accordance with environmental drivers, boxes indicate leastsquares means, error bars indicate $95 \%$ confidence interval of the least square means. Means sharing a letter are not significantly different (Tukey-adjusted comparison).

Figure 3.4 Daily sap flux densities $\left(\mathrm{J}_{\mathrm{s}}\right)$ of the four study species versus daily soil water content (SWC).

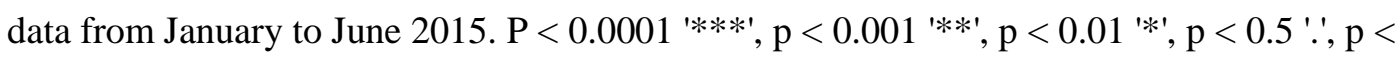
$0.1^{\prime \prime}$.

Figure 3.5 Daily sap flux densities $\left(\mathrm{J}_{\mathrm{s}}\right)$ of the four study species plotted against average daily VPD. Filled symbols indicate wet conditions ( $\mathrm{SWC}>25 \%$ ), open symbols dry conditions (SWC $<15 \%$ ) (data from two weeks per period). Logarithmic regressions were fitted to the data. $\mathrm{P}<0.0001^{\prime * * * ', p}<0.001^{\prime * * '}, \mathrm{p}<0.01^{\prime *}, \mathrm{p}<0.5^{\prime}$. ', $\mathrm{p}<0.1^{\prime}$ ', $\mathrm{R}^{2}$ is given in italics. Daily sap flux densities derived from measurements of $\mathrm{n}=$ four individuals per species per altitude and treatment.

Figure 3.6 Diurnal hysteresis loops showing the relationship between hourly sap flux density and VPD for dry $(16.02 .2015, \mathrm{SWC}=7.4 \%)$ and wet $(13.04 .2015, \mathrm{SWC}=25.8 \%)$ soil conditions. Solid line indicates wet conditions, dashed line dry conditions; arrows show direction of rotation with time of the day. Hourly averages were derived from simultaneous measurement of $n=4$ trees on a sunny day.

Figure 4.1 Deuterium concentration in transpired water over the duration of the experiment. The deciduous species were sampled at three different altitudes $(670 \mathrm{~m}, 860 \mathrm{~m}, 1100 \mathrm{~m}$ asl.).

Figure 4.2 (a) Tracer velocity (m day-1), (b) water use (kg day-1), and (c) tracer residence time (days) in relation to tree $\mathrm{DBH}(\mathrm{N}=35)$

Figure 4.3 Plant water residence time (days) estimated from deuterium tracing in relation to (a) tree DBH and (b) wood density in this study $(\mathrm{n}=5)$ and from other studies $(\mathrm{n}=25)$. The two outliers with residence time $>40$ days were removed from the regression analysis. See Table S2 in the appendix for a full list of cited studies and species. Wood density taken from Chave et al. (2009) and Zanne et al. (2009).

Figure 5.1 Climate change in relation to interactions amongst environmental inputs, stem water status of trees and its determinants, and phenological characteristics in dry tropics (adapted from Borchert, 1999). Direction of arrow is from the affecting to the affected factor. 


\section{Index of tables}

Table 2.1 Characteristics of tree species and trees studied (mean \pm SE), wood density taken from Zanne et al., 2009.

Table 2.2 Linear correlations between sap flux density and VPD, and change in circumference and SWC,

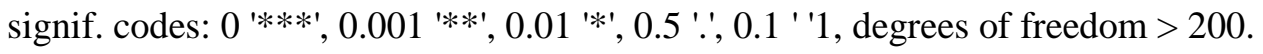

Table 2.3 Seasonal tree responses in leaf phenology, radial variation and sap flux to moisture fluctuations. Arrows indicate increase, decrease or constant behavior; n.a.-data not available due to maintenance of sap flux installations.

Table 3.1 Characteristics of the four studied tree species (mean \pm SD, $n=4$ trees per elevation), wood density taken from Zanne et al. 2009.

Table 3.2 Soil water content (SWC, \%) in the study period at three altitudes ( $\mathrm{n}=4$ reflectometer probes at $0-30 \mathrm{~cm}$ depth, mean $\pm \mathrm{SD}$ ), monthly means were tested across altitudes and across month with ANOVA followed by Tukey test. The lower case letters indicate statistical differences $(p<0.05)$ between altitudes, the upper case letters between months.

Table 3.3 Maximum sap flux densities under dry and wet soil conditions. Two weeks period in the 2015 rain period with low $(<15 \%)$ and high $(>25 \%)$ soil water content $(\mathrm{SWC}) . \mathrm{n}=4$ trees per species, mean \pm SD. Maximum sap flux densities were tested using ANOVA followed by Tukey test. Letters indicate significant difference $(\mathrm{p}<0.05)$ between SWC, altitude and species.

Table 3.4 Anova table from mixed linear Model 1 (mixed effects model) with main effects of soil water content (SWC), vapor pressure deficit (VPD), species, elevation as fixed effects, tree size $(\mathrm{DBH})$ as covariate and species identity as random effect on daily sap flux density for the whole study period. The following two way interactions: SWC:species, SWC:elevation, species:elevation, VPD:species, VPD:elevation and SWC:VPD were included. Significance

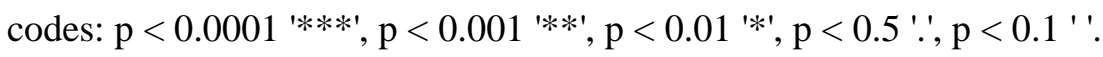

Table 4.1 Characteristics of tree species studied (mean with SD in brackets), wood density taken from Chave et al. (2009) and Zanne et al. 2009.

Table 4.2 Key results from the deuterium tracing experiment (mean with SD in brackets). Data of the deciduous species was derived from three different altitudes. $\mathrm{T}=$ time, $\mathrm{V}=$ velocity, $\mathrm{WU}=$ water use. Different lowercase letters indicate significant differences between species; different capital letters indicate significant difference between tree phenologies at $p<0.05$. 


\section{Acknowledgements}

First and foremost, I have to thank my supervisor Dirk Hölscher for his friendly, innovative, endless and leading support and advice throughout the entire time it took me to compose this work, during field work preparation, data analysis, manuscript writing and endless reviews. It was a pleasure and I profited a lot, thank you very much!

Also big thank you goes to Sophie Graefe for always being there with advice and time during all different phases of this work: during plot setup, field work, data analysis, manuscript writing and reviews. Thank you very much dear Sophie!

Thanks to Mr. and Mr. for agreeing to be on the committee and rating of this work.

I would also like to thank Eva Siegelkow, for incredibly efficient administrative support from Göttingen to my study site in Ecuador (without your fast responses to my money requests it would have been very difficult!), as well as everyone in the department, for having nice and interesting discussions and being very dear colleagues.

Special thanks to Alejandra and Issaka for our sap flux discussion-support group, it was always very nice and helpful to discuss with you guys!

Big thanks also to the managers of the research facilities in Ecuador, Felix and Jörg and all the staff of the ECSF (Maria, Tatti, Robert and José). And of course to my fellow PhD colleagues I met along my way, especially you Marta!

Finally, I like to thank my friends and even more my family, who supported me and somehow made it possible in the first place to achieve this work, Danke euch vielmals Haike und Henning! 


\section{Declaration of honor}

I hereby declare that I am the sole author of this dissertation entitled "FUNCTIONAL WATER USE STRATEGIES OF A NEOTROPICAL DRY FOREST" and that all references and data sources have been acknowledged as such. I further declare that this work has never been submitted in any form as part of any other dissertation procedure.

Göttingen, 25. June 2019,

Philipp Butz 


\section{Curriculum vitae}

Name

Date of birth

Place of birth

Citizenship

\section{Education}

Primary school

Secondary school

\section{Higher education}

B.Sc. $(2006-2010)$

M.Sc. (2010-2013)

PhD (2014-2017)
Jan Philipp Butz

23.09.1986

Duisburg, Germany

German

Grundschule Barrien, Germany

Gymnasium Syke, Germany

Forest Sciences and Forest Ecology, Georg-AugustUniversität Göttingen

Internship Forestry Service Fuhrberg, Germany (OctDec 2006)

Tropical Ecology and International Forestry, Tropical Silviculture and Forest Ecology, Georg-AugustUniversität Göttingen

International student project: Development of a Forest Region in Yogyakarta (Wanagama Educational Forest), Indonesia (Nov 2011)

Master thesis field work in Loja-Zamora, Ecuador (Aug-Dec 2012)

Ecohydrology and Forest Ecology, Tropical Silviculture and Forest Ecology, Georg-AugustUniversität Göttingen 
$\mathrm{PhD}$ thesis field work in Laipuna Forest Reserve (Loja Province), Ecuador (Feb-Aug 2014, Jan-Jul 2015)

\section{Scientific positions}

2013

2014-2017

\section{Peer-reviewed publications}

2017

2018

2019
Scientific assistant in the department of wood biology and technology (Jul-Dec 2013)

PhD-position in the DFG PAK 823-825: Platform for Biodiversity and Ecosystem Monitoring and Research in South Ecuador, Georg-August University Göttingen.

Butz, P.*, Raffelsbauer, V.*, Graefe, S., Peters, T., Cueva, E., Hölscher, D., Bräuning, A.: Tree responses to moisture fluctuations in a Neotropical dry forest as potential climate change indicators, Ecological Indicators ( 2017), 83, 559-571, doi:10.1016/j.ecolind.2016.11.021

Butz, P.*, Hölscher, D., Cueva, E., Graefe, S.: Tree water use patterns as influenced by phenology in a dry forest of southern Ecuador, Frontiers in Plant Science (2018), 9, 945, doi:10.3389/fpls.2018.00945

Graefe, S.*, Fang, D., Butz, P.: Water residence times in trees of a neotropical dry forest, Trees (2019), doi: 10.1007/s00468-019-01849-y 